\title{
A study of the relationship between the leadership images of West Virginia superintendents and directed modes of thinking
}

Dianna M. Vargo

West Virginia University

Follow this and additional works at: https://researchrepository.wvu.edu/etd

\section{Recommended Citation}

Vargo, Dianna M., "A study of the relationship between the leadership images of West Virginia superintendents and directed modes of thinking" (2009). Graduate Theses, Dissertations, and Problem Reports. 4545.

https://researchrepository.wvu.edu/etd/4545

This Dissertation is protected by copyright and/or related rights. It has been brought to you by the The Research Repository @ WVU with permission from the rights-holder(s). You are free to use this Dissertation in any way that is permitted by the copyright and related rights legislation that applies to your use. For other uses you must obtain permission from the rights-holder(s) directly, unless additional rights are indicated by a Creative Commons license in the record and/ or on the work itself. This Dissertation has been accepted for inclusion in WVU Graduate Theses, Dissertations, and Problem Reports collection by an authorized administrator of The Research Repository @ WVU.

For more information, please contact researchrepository@mail.wvu.edu. 
A Study of the Relationship between the Leadership Images of West Virginia Superintendents and Directed Modes of Thinking

Dianna M. Vargo

\author{
Dissertation submitted to the \\ College of Human Resources and Education \\ at West Virginia University \\ in partial fulfillment of the requirements \\ for the degree of
}

Doctor of Education

in

Educational Leadership Studies

\author{
Richard Hartnett, Ed.D., Chair \\ Paul Chapman, Ph.D. \\ Helen Hazi, Ph.D. \\ Neal Shambaugh, Ph.D \\ Kathy M. Finsley, J.D. \\ Department of Educational Leadership Studies
}

Morgantown, West Virginia

2009

Keywords: Superintendents, Leadership Images, Wizard, Warrior, L-Directed Thinking, RDirected Thinking. 


\begin{abstract}
A Study of the Relationship between the Leadership Images of West Virginia Superintendents and Directed Modes of Thinking
\end{abstract}

\title{
Dianna M. Vargo
}

This study examines the relationship between leadership images of West Virginia public school superintendents and their directed modes of thinking. The Leadership Images: A Leadership Self-Inventory Instrument was used to collect data from the superintendents regarding their leadership images. The Keirsey's FourTypes Sorter was used to collect data from the superintendents regarding their directed modes of thinking. Also, the superintendents were asked to respond to five qualitative questions related to the work they do as superintendents. The surveys were used along with a demographic questionnaire that collected information regarding gender, size of the student population, student free and reduced status, number of years as superintendent, number of years in the school system, and number of years of experience in education. The surveys and questionnaire were sent to the 55 public school superintendents in West Virginia. Responses were received from 44 superintendents. Chi-Square Tests of Independence were computed to determine the level of significance.

Major research findings indicate no statistically significant relationship between leadership images and directed modes of thinking. The majority of the West Virginia superintendents are wizards and have a tendency to be L-Directed Thinking.

There is a statistically significant relationship between directed modes of thinking and gender. This finding signifies a heightened relationship between directed modes of thinking and gender. The majority of the West Virginia female superintendents have a tendency to be wizards and the majority of the West Virginia female superintendents have a tendency to be R-Directed Thinking.

Recommendations from this study include implementation of professional development activities for superintendents with a focus on an increased awareness of their leadership images and directed modes of thinking. Also, further research may be done on gender and directed modes of thinking. 


\section{DEDICATION}

I dedicate this effort to the students of Ohio County Schools. I never cease to draw inspiration from your desire to learn. 


\section{ACKNOWLEDGEMENTS}

My completion of this doctoral program would not have been possible without the support, understanding, and encouragement of many. First and foremost, I must thank my committee chairperson, Dr. Richard Hartnett, whose patient guidance and most astute insight and creativity were invaluable to my effort. My sincere appreciation must also be extended to the members of my doctoral committee: Dr. Paul Chapman, Kathy Finsley, Dr. Helen Hazi, and Dr. Neal Shambaugh who provided me with critical instruction throughout this experience. I further wish to thank and acknowledge Dr. Reagan Curtis for his generous contribution of time and statistical application to my study.

Finally, I wish to thank Superintendent of Ohio County Schools, Lawrence M. Miller, and Deputy Superintendent of Ohio County Schools, George S. Krelis, for their continued support. 


\section{TABLE OF CONTENTS}

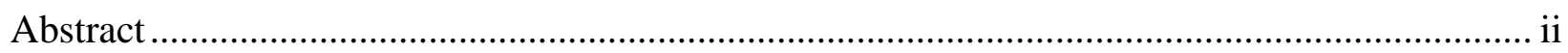

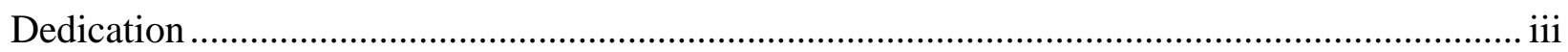

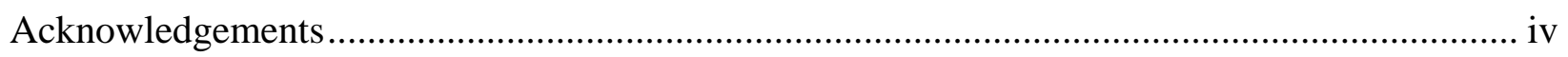

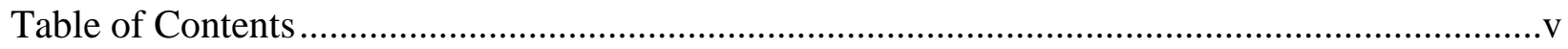

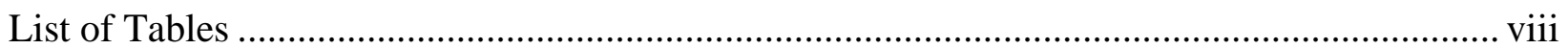

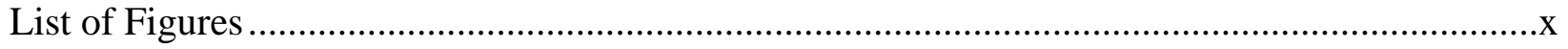

CHAPTER 1 - Introduction to the Study ....................................................................

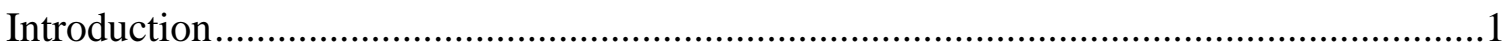

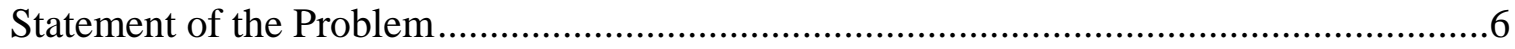

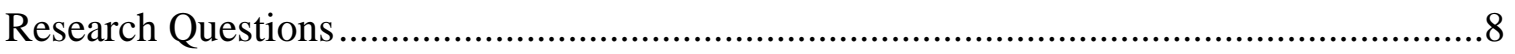

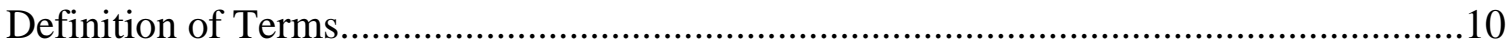

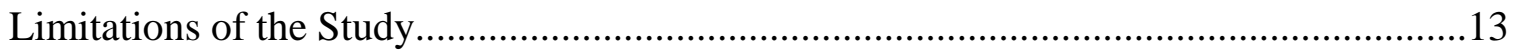

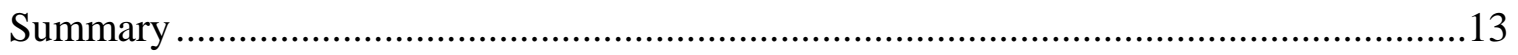

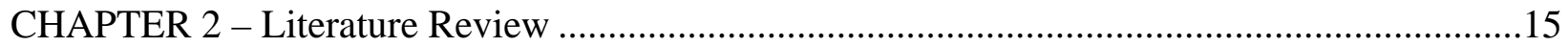

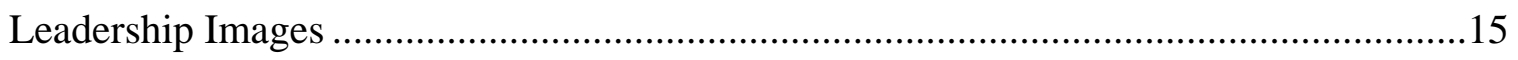

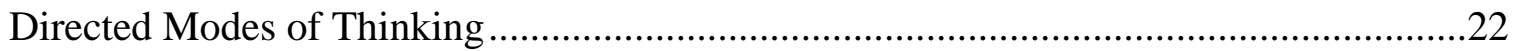

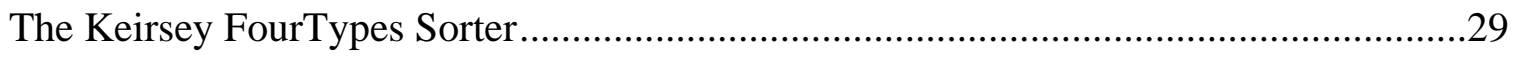

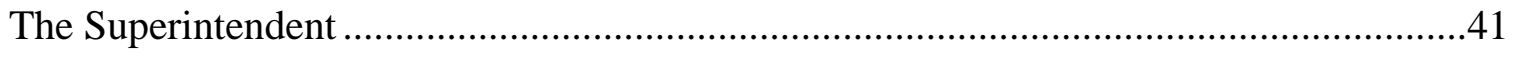

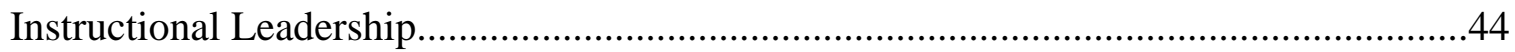

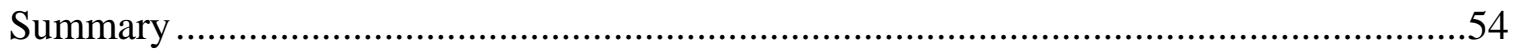

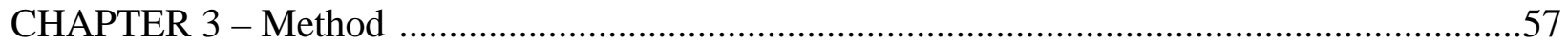

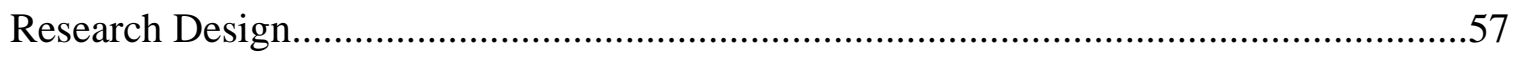


Population and Sample ……………………………..................................................58

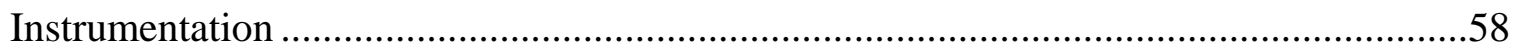

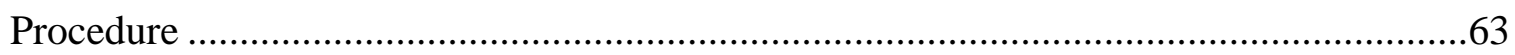

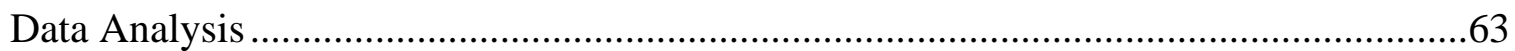

Confidentiality and Anonymity .............................................................................66

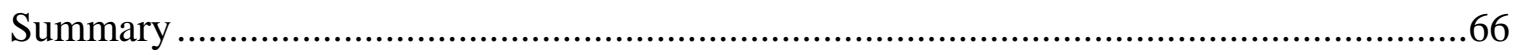

CHAPTER 4 - Presentation and Analysis of Data ........................................................................6

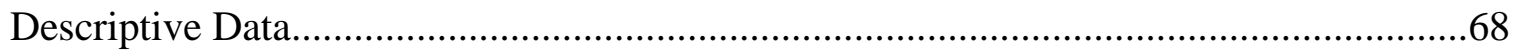

Statistical Analysis of Data...........................................................................................

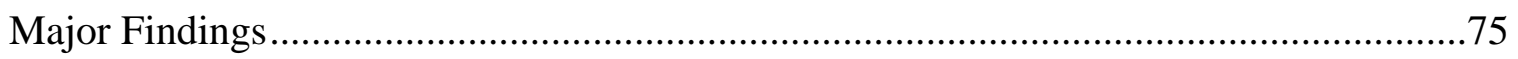

Research Question 1 .............................................................................................75

Research Question 2 ..................................................................................................

Research Question 3 .................................................................................................76

Research Question 4 ............................................................................................77

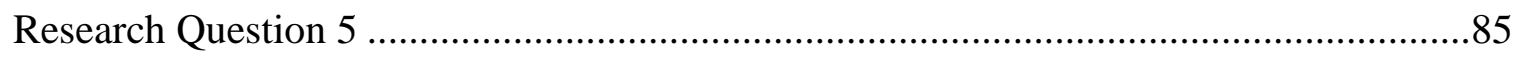

Qualitative Survey Questions .........................................................................................93

Profile of the Typical Superintendent ..........................................................................95

Summary of the Chapter .................................................................................................96

CHAPTER 5 - Conclusions, Further Analyses, Implications and Recommendations...................98

Conclusions and Further Analyses.................................................................................98

Leadership Images of West Virginia Superintendents.......................................................98

Directed Modes of Thinking of West Virginia Superintendents .....................................100

Leadership Images and Directed Modes of Thinking......................................................101

Demographic Effect on Leadership Images..................................................................103 
Demographic Effect on Directed Modes of Thinking ..............................................104

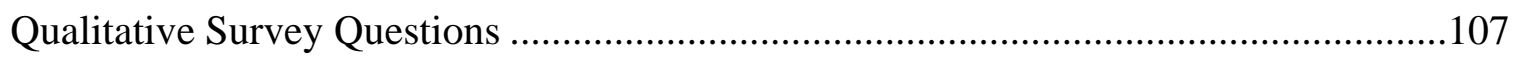

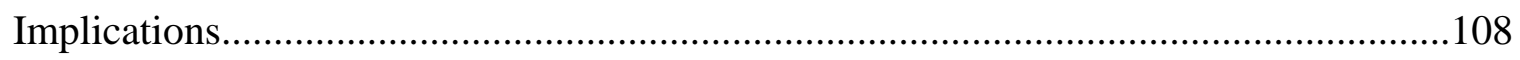

Implications for Educational Leaders …............................................................109

Implications for State Educational Organizations ................................................110

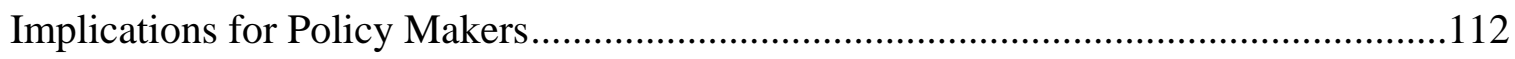

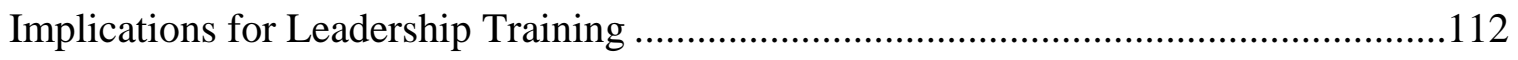

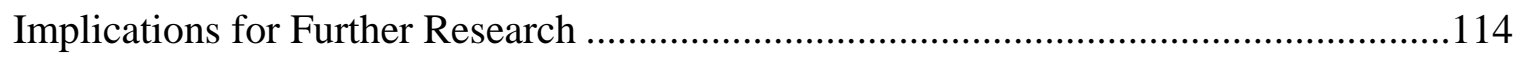

Recommendations for Further Research..........................................................115

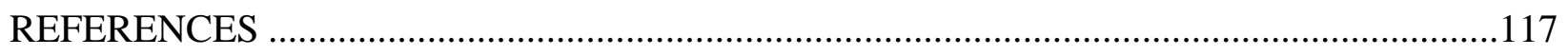

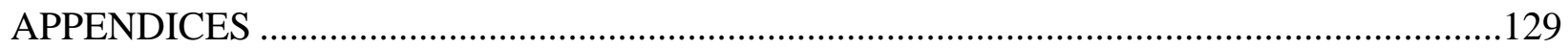

A. Leadership Self-Inventory Survey .............................................................129

B. Permission to Use Leadership Self-Inventory Survey .........................................132

C. Keirsey FourTypes Sorter .........................................................................133

D. Permission to Use Keirsey FourTypes Sorter ......................................................134

E. Demographic Information and Survey Questions.............................................135

F. West Virginia Superintendents ..................................................................136

G. Cover Letter to Superintendents, First Mailing ................................................137

H. Cover Letter to Superintendents, Second Mailing ..............................................138

I. Approval by the West Virginia University Institutional Review Board

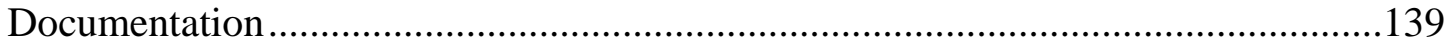

Human Research Curriculum Completion Report................................................141

J. Letter of Support from Dr Steven Paine ..........................................................142

K. VITA - Dianna M Vargo ...........................................................................143 


\section{TABLES}

Table 1 Frequency Distribution of Respondents by Gender..

Table 2 Frequency Distribution of Respondents by Total Years in Education .69

Table 3 Frequency Distribution of Respondents by Total Years in Current School System .....70

Table 4 Frequency Distribution of Respondents by Total Years as Superintendent .................71

Table 5 Frequency Distribution of Respondents by Size of Student Population........................72

Table 6 Frequency Distribution of Respondents by Student Free and Reduced Status.............73

Table 7 Frequency Distribution of Respondents by Leadership Image.................................75

Table 8 Frequency Distribution of Respondents by Directed Mode of Thinking .....................76

Table 9 Leadership Images and Directed Modes of Thinking............................................77

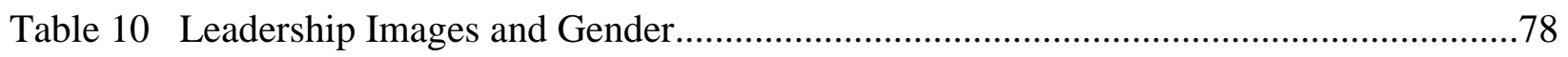

Table 11 Leadership Images and Size of Student Population...............................................79

Table 12 Leadership Images and Student Free and Reduced Status ......................................80

Table 13 Leadership Images and Number of Years as Superintendent .................................81

Table 14 Leadership Images and Number of Years as Superintendent ...................................82

Table 15 Leadership Images and Number of Years in School System...................................83

Table 16 Leadership Images and Number of Years in School System....................................84

Table 17 Leadership Images and Number of Years of Experience .......................................85

Table 18 Directed Modes of Thinking and Gender ...........................................................86

Table 19 Directed Modes of Thinking and Size of Student Population ...................................87

Table 20 Directed Modes of Thinking and Student Free and Reduced Status .........................88

Table 21 Directed Modes of Thinking and Number of Years as Superintendent.......................89

Table 22 Directed Modes of Thinking and Number of Years as Superintendent.......................90 
Table 23 Directed Modes of Thinking and Number of Years in School System .......................91

Table 24 Directed Modes of Thinking and Number of Years in School System ......................92

Table 25 Directed Modes of Thinking and Number of Years of Experience...........................93

Table 26 Profile of the Typical Superintendent .................................................................95 


\section{FIGURES}

Figure 1 Descriptions of the Sixteen Myers-Briggs Types.................................................30

Figure 2 The Traits of Temperament and Character..........................................................39 


\section{Chapter 1}

Introduction

Educational leaders today face tremendous pressure to prepare students with the fundamental knowledge and skills to be successful in the $21^{\text {st }}$ century. Since the publication of $A$ Nation At Risk in 1983, school systems have strived to raise the academic requirements for all students. In 2001, the No Child Left Behind (NCLB) legislation, a national educational reform, became law under President George W. Bush. This act challenged educators to establish educational standards that support achievement for all students defined by nine subgroups. The nine subgroups include: all students, economically disadvantaged, racial/ethnicity white, racial/ethnicity black, racial/ethnicity Hispanic, racial/ethnicity Asian, racial/ethnicity American Indian/Alaskan, students with disabilities, and limited proficiency students. School systems are measured annually by student performance on statewide assessments. The results of the assessments determine if school systems comply with the adequate yearly progress (AYP) provision of NCLB. Currently, educators and public officials are conversing about the reauthorization of NCLB. The reauthorization of the law will focus on support for struggling schools and the improvement of academic performance for older students (U. S. Department of Education, 2007). Without a doubt, educational leaders continue to face new challenges as they lead their school systems into the $21^{\text {st }}$ century.

In response to these challenges, in the summer of 2005, the Governor of West Virginia, Joe Manchin, and the West Virginia State Superintendent of Schools, Steven Paine, formed a promising partnership with $21^{\text {st }}$ Century Skills. The partnership identifies six elements of a $21^{\text {st }}$ century education: emphasize core subjects, emphasize learning skills, use $21^{\text {st }}$ century tools to develop learning skills, teach and learn in a $21^{\text {st }}$ century context, teach and learn $21^{\text {st }}$ century 
content, and use $21^{\text {st }}$ century assessments that measure $21^{\text {st }}$ century skills (Crane, 2002). The implementation of the partnership has defined 40 initiatives that are being addressed at both the state and local levels (West Virginia Department of Education, 2006). Local leadership teams receive support implementing these initiatives by attending leadership conferences sponsored by the West Virginia Department of Education.

As educational leaders define the skills needed for students to be successful in the $21^{\text {st }}$ century, they are examining student test scores. A study comparing the test scores of students in the United States with the test scores of students from other countries linked grade eight scores on the 2003 Trends in International Mathematics and Science Study (TIMSS) with achievement levels on the National Assessment of Educational Progress (NAEP) and ranked the United States tenth in science and fifteenth in mathematics in comparison to students in other countries (Manzo \& Cavanagh, 2008). It is evident that American students are not measuring up with students from other countries. Furthermore, the Quality Counts 2008 report indicates that states have been awarded overall letter grades based on their ratings across six areas of accountability, including transitions and alignment; the teaching profession; and school finance (Swanson, 2008). The overall average grade in the Quality Counts 2008 report for schools in the United States is a "C" (Swanson, 2008). However, the overall state grade for schools in West Virginia is a "B minus" (Swanson, 2008). Not only are these statistics alarming to educational leaders today but they pose challenges that educational leaders must be willing to embrace.

In 2007, the National Center on Education and the Economy published the report, Tough Choices or Tough Times. This report presents three concerns for current educational leaders. First, American workers are competing for jobs with workers from other countries who are willing to accept lower wages than American workers (National Center on Education and the 
Economy, 2007). Students must be able to compete in the global job market. Second, the college going rate for students in the United States has decreased from 30\% to $14 \%$ over the past 30 years and is continuing to fall (National Center on Education and the Economy, 2007). School systems must be willing to restructure education so that it prepares students for postsecondary education and life long learning. Finally, the report indicates that the educational system in the United States has traditionally tested students on routine work and has not provided opportunities for students to be creative and innovative thinkers (National Center on Education and the Economy, 2007). Test scores alone do not prepare students for jobs when they are competing with students from other countries. In order for students to competitively enter the global economy, they must possess the skills to apply what they learn in school to the real world of work (Zhao, 2007). Educational leaders may encourage creative and innovative thinking by offering a curriculum that supports problem based learning, standards based learning, and differentiated instruction.

Educational leaders are being faced with the challenge of adapting to the needs of a $21^{\text {st }}$ century society, in addition to the challenges presented by federal legislation, state policies, and globalization. According to Marx (2006), there are 16 trends that have a profound impact on the future of society and education. These trends indicate a need to reshape the direction of society and education by changing the thinking and planning of leaders. For example, one important trend states that pressure will grow for society and education to prepare people and students for jobs that may not currently exist (Marx, 2006). This trend tells leaders that remaining at the status quo is not good enough. Educational leaders as well as business leaders will have to make changes in order to keep school systems moving forward. Bracey (2008) states that schools alone should not be accountable for innovation and inventions. Teaming with business partners 
is one way to enhance the preparation of students to become $21^{\text {st }}$ century learners. Business leaders are able to inform educational leaders of necessary skills for employment. Educational leaders may be asked to change how technology is integrated into the curriculum, hire technology integrated specialists, and develop project-based learning. The knowledge of educational leaders and business leaders may be intertwined to produce the student and worker who can compete globally.

At the helm of educational leaders in a school system are the superintendents. The role of superintendents is to serve as the chief executive officers of school systems. Blumberg (1985) states that one responsibility of superintendents is to improve educational opportunities for students. Research shows that a wave of school reform occurred in the 1990s known as systemic reform (Hoy and Miskel, 2005). Systemic reform became synonymous with school improvement. Topics such as accountability, standards, academic achievement, performance assessments, and formative assessments were emphasized by superintendents to improve their school systems. Furthermore, research shows that district-level strategies have increased academic progress in school systems (Fullan, 2003). District-level strategies may include the following: focus on student achievement and specific achievement goals, concrete accountability system, focus on the lowest-performing schools, adopted or developed districtwide curricular and instructional approaches, central office support, and data-driven decisionmaking (Fullan, 2003).

In 2001, as a result of the NCLB requirements, the demands to meet annual AYP standards, and a myriad of social and economic factors, the complexity of the superintendent's leadership role has increased tremendously. Kouzes and Posner (2007) define five practices of exemplary leadership: model the way, inspire a shared vision, challenge the process, enable 
others to act, and encourage the heart. These practices may be used by superintendents today as they tackle the challenges of the $21^{\text {st }}$ century. In addition to these research-based practices, research exists about the image and directed modes of thinking of $21^{\text {st }}$ century leaders.

Today, since school systems are required to establish high academic standards for all students, the demands upon the learning community and its leadership are critical to success. The leadership images of superintendents are imperative because they will ultimately impact many components of the entire system. The $21^{\text {st }}$ century superintendents should have an image of leadership (Bolman \& Deal 2003, 2006). Bolman and Deal define the images of leadership as being either a wizard or a warrior. Research shows how individuals within each image think, how they work, what drives them, and the benefits of both images (Bolman \& Deal, 2006). All are characteristics that superintendents possess which directly impact the district, its operations, and its results.

Research (Pink, 2006; Zhao, 2007) points to the relevance of the relationship between directed modes of thinking and leadership practices as the economy and society move from the Information Age to the Conceptual Age. Pink (2006) separates the directed modes of thinking into two hemispheres: L-Directed Thinking and R-Directed Thinking. L-Directed Thinking is associated with left brain characteristics which are sequential, literal, functional, textual, and analytic and R-Directed Thinking is associated with right brain characteristics which are simultaneous, metaphorical, aesthetic, contextual, and synthetic (Pink, 2006). Research (Pink, 2006; Zhao, 2007) indicates that L-Directed Thinking is important; however, R-Directed Thinking must supplement L-Directed Thinking in order for superintendents to lead successfully into the future. The way that superintendents think as they embrace the challenges of the $21^{\text {st }}$ 
century will impact how they lead their school systems from the Information Age into the Conceptual Age.

Thomas (2001) examined research on leadership effectiveness focusing on the public school superintendency in the twenty-first century. Historical concepts in Thomas' (2001) research refer to the challenges of educational leadership at the end of World War II because reformers were advocating for a curriculum that would prepare students for the demands of society. References to how leadership effectiveness is measured included student growth and achievement, job priorities, effects on instructional leadership, perceptions of effectiveness, influence on school culture, and problem solving skills (Thomas, 2001). In summarizing her research findings, Thomas (2001) states, "Research continues to lack a clear definition and agreed upon measures of what constitutes effective school system leadership, and offers little information on how superintendents can improve their leadership styles” (p. 10). Thomas (2001) made recommendations for further research. She suggested that more information is needed about how superintendents can improve their leadership styles and specifically recommends further research on providing information for preparing effective educational leaders.

\section{Statement of the Problem}

School superintendents are ultimately responsible for the operation of their entire school systems. The successes and failures of the systems point directly to the superintendents. In order to be kept up to date on school policies, procedures, and current research, superintendents attend national, state, and local conferences as well as subscribe to educational journals. Superintendents have benefited from the information obtained from these sources. Today, as school systems move from the Information Age to the Conceptual Age, it is important to know how superintendents see themselves and how they think. However, there is no current research 
linking the images of the superintendent as defined by Bolman and Deal (2006) and directed modes of thinking. Any information in these areas is powerful in the preparation and selection of superintendents and emerging superintendents as they lead school systems into the $21^{\text {st }}$ century.

According to research (Bolman \& Deal, 2003, 2006; Friedman, 2005; Zhao, 2007) school systems can flourish in the $21^{\text {st }}$ century if superintendents have the right imagination. Superintendents may use creative thinking to help with the transition of leading in a world of change and to adjusting the needs of their school systems to meet the change. The leadership images are defined on the premises of Bolman and Deal's (2006) images of leadership (wizard and warrior) to understand leadership behaviors of superintendents and how they fulfill their mission. The directed modes of thinking, L-Directed Thinking and R-Directed Thinking, are defined by Pink (2006). The directed modes of thinking of the West Virginia superintendents are identified by Keirsey's four temperaments. The four temperaments are Guardian, Rational, Artisan, and Idealist. The Guardian and Rational overlay Bolman and Deal's concept of the warrior and demonstrate characteristics such as quantitative, logistical, and strategic which are associated with L-Directed Thinking (Bolman \& Deal, 2003, 2006; Keirsey \& Bates, 1984; Keirsey, 1998; Pink, 2006). Whereas, the Artisan and Idealist overlay Bolman and Deal's concept of the wizard and demonstrate characteristics such as qualitative, artistic, and authentic which are associated with R-Directed Thinking (Bolman \& Deal, 2003, 2006; Keirsey \& Bates, 1984; Keirsey, 1998; Pink, 2006).

As school superintendents lead their educational systems into the $21^{\text {st }}$ century, their leadership image and the way they think will impact how they lead. The information provided in this study will create an awareness of leadership images and will allow superintendents and 
emerging superintendents to identify these images within themselves. Also, the information provided in this study will create an awareness of directed modes of thinking and will allow superintendents and emerging superintendents to identify these modes of thinking within themselves. Furthermore, this study will examine if there is a statistically significant (>.05) relationship between the leadership images of West Virginia superintendents and directed modes of thinking.

\section{Research Questions}

This research investigates the leadership images of West Virginia superintendents and their directed modes of thinking. The study invited all superintendents in West Virginia to participate in the surveys. The study seeks to answer the following five research questions.

Question 1. What are the leadership images (as measured by Bolman and Deal's images of leadership) of West Virginia superintendents?

The Bolman and Deal’s (2006), The Leadership Images: A Leadership Self-Inventory was utilized to collect data regarding Research Question 1. The frequencies and percentage of the superintendents who utilized patterns of either a wizard or warrior were identified and reported. If the score for the wizard and the warrior are tie, then the superintendents' responses to item number twelve on the instrument was used to determine if the superintendents' were wizards or warriors. Item number twelve on the survey instrument asks the superintendents if they are an analyst, a caregiver, a warrior or a wizard. If the wizard receives the higher mark, then the superintendents will be categorized as wizards. If the warrior receives the higher mark, then the superintendents will be categorized as warriors.

Question 2. What are the temperaments, L-Directed Thinking or R-Directed Thinking, (as measured by The Keirsey FourTypes Sorter) of West Virginia superintendents? 
The Keirsey FourTypes Sorter (1998) was utilized to collect data regarding Research Question 2. The frequencies and percentages of the superintendents who utilized patterns of either L-Directed Thinking or R-Directed Thinking were identified and reported.

Question 3. Is there a statistically significant (>.05) relationship between leadership images and directed modes of thinking?

To examine Research Question 3, a Chi-Square Test of Independence was conducted on leadership images (wizard or warrior) and directed modes of thinking (L-Directed Thinking or R-Directed Thinking).

Question 4. Are there statistically significant (>.05) differences in leadership images of West Virginia superintendents by gender (male or female), size of the student population in the school system $($ small $=$ less than 3000/medium $=3000-6000 /$ large $=$ more than 6000 ), the student free and reduced status of the school system (low $=$ less than $50 \% /$ medium $=50 \%-60 \% /$ high $=$ more than $60 \%$ ), the number of years as the superintendent $($ emergent $=0-5$ years $/$ mid-career $=$ 6-10 years/established $=$ more than 10 years), the superintendent's number of years in the school system $($ emergent $=0-5$ years $/$ mid-career $=6-10$ years/established $=$ more than 10 years $)$ and the superintendent's number of years of experience in education $($ emergent $=0-5$ years $/$ mid-career $=$ 6-10 years/established $=$ more than 10 years $)$ ?

To examine Research Question 4, a series of six Chi-Square Tests of Independence were conducted on leadership images (wizard or warrior) by demographic variables (Gender, School Size, Student Free and Reduced Status, and Years of Experience as Superintendent, Years of Experience in School System, and Years of Experience in Education).

Question 5. Are there statistically significant (>.05) differences in the directed modes of thinking of West Virginia superintendents by gender (male or female), size of the student 
population in the school system (small = less than 3000/medium $=3000-6000 /$ large $=$ more than 6000), the student free and reduced status of the school system (low $=$ less than $50 \% /$ medium $=$ $50 \%-60 \%$ / high $=$ more than $60 \%$ ), the number of years as the superintendent (emergent $=0-5$ years $/$ mid-career $=6-10$ years/established $=$ more than 10 years $)$, the superintendent's number of years in the school system $($ emergent $=0-5$ years $/$ mid-career $=6-10$ years $/$ established $=$ more than 10 years) and the superintendent's number of years of experience in education (emergent = 0-5 years $/$ mid-career $=6-10$ years/established $=$ more than 10 years $) ?$

To examine Research Question 5, a series of six Chi-Square Tests of Independence were conducted on directed modes of thinking (L-Directed Thinking or R-Directed Thinking) by demographic variables (Gender, School Size, Student Free and Reduced Status, Years of Experience as Superintendent, Years of Experience in School System, and Years of Experience in Education).

\section{Definition of Terms}

Wizard. A leader, defined as a wizard, brings imagination, insight, creativity, vision, meaning, and magic to the work of leadership (Bolman \& Deal, 2006).

Warrior. A leader, defined as a warrior, believes managers and leaders live in a world of conflict and scarce resources (Bolman \& Deal, 2006).

L-Directed Thinking. A form of thinking and an attitude to life that is characteristic of the left hemisphere of the human brain. Its thinking processes are sequential, literal, functional, textual, and analytic (Pink, 2006). L-Directed Thinking is directed by the left brain. The Guardian and Rational are associated with L-Directed Thinking.

R-Directed Thinking. A form of thinking and an attitude to life that is characteristic of the right hemisphere of the human brain. Its thinking processes are simultaneous, metaphorical, 
aesthetic, contextual, and synthetic (Pink, 2006). R-Directed Thinking is directed by the right brain. The Artisan and Idealist are associated with R-Directed Thinking.

Superintendent. The superintendent is an officer of the county school district and acts as the chief executive officer of the county board (West Virginia School Laws Annotated, 2007).

\section{Significance of Study}

As mentioned, little research exists regarding how superintendents can improve their leadership styles. As stated by Thomas (2001),

Like other organizational managers, the educational CEO’s job is highly contextual, and leadership effectiveness is highly sensitive to that context. Educational superintendents must simultaneously function as educational leaders, politicians, and organizational managers to influence any significant change in their districts. A clear understanding of how successful CEO’s function in each role is needed to move this research forward (p.11).

Research on the superintendency suggests that important roles of the superintendent include creating a budget, developing a positive school environment, supporting faculty, staff, and students, and providing an effective curriculum (Blumberg, 1985; Carter, 1993; Kowalski, 2005; Lashway, 2002, 2003; Petersen, 1999; Rammer, 2007; Thomas, 2001). Because of the demands of the accountability system on each of these areas, leadership roles of the superintendent are crucial in meeting the needs of the entire school system. Research by Kouzes and Posner (2003, 2007) indicates that the way leaders accomplish the goals of the organization are based on five common practices that lead to exemplary leadership. Thus, the way superintendents see themselves and the way they think impacts how the goals of the organization are accomplished. 
The leadership images of superintendents in West Virginia and their directed modes of thinking are being investigated in this study. The study will examine if there is a relationship between the leadership images of superintendents in West Virginia and their directed modes of thinking. This study will be the first research that has been conducted on leadership images of West Virginia superintendents and their directed modes of thinking using Bolman and Deal's (2006) Leadership Self-Inventory and the Keirsey FourTypes Sorter (1988).

Furthermore, this study provides pertinent information that is significant for the following reasons:

1. The research results will create an awareness of leadership images for current and emerging superintendents.

2. The research results will show how leadership images impact leadership behaviors.

3. The research results will create an awareness of directed modes of thinking for current and emerging superintendents.

4. The research results will show how directed modes of thinking impact leadership behaviors.

5. The research will provide the superintendents with the opportunity to determine their strengths, weaknesses, opportunities, and threats (SWOT).

6. The research will provide the West Virginia State Superintendent with a snapshot of the images and directed modes of thinking for current West Virginia superintendents.

7. The research will provide the West Virginia Department of Education with a snapshot of the images and directed modes of thinking for current West Virginia superintendents that may assist in the planning of professional development sessions offered to the West Virginia superintendents. 
8. The research will be of interest to higher education leadership departments as they apply the findings to preparation programs for educational leaders, particularly emerging superintendents.

9. The research findings may serve as a basis for West Virginia Board of Education policy development in regard to performance expectations of superintendents.

10. The results may be used by the West Virginia Legislature in the development of laws defining the qualifications and leadership training programs of superintendents.

\section{Limitations of the Study}

1. The study was limited to West Virginia superintendents.

2. The demographics of the school system may influence the leadership images and directed modes of thinking of the superintendents.

3. The background information of the superintendents may influence the leadership images and directed modes of thinking of the superintendents.

4. The lack of reliability and validity of Bolman and Deal's (2006) The Leadership Images: A Leadership Self-Inventory.

\section{Summary}

The role of the school superintendent, the chief executive officer, is to accomplish the goals of the school system by carrying out the mission. The superintendent is ultimately responsible for the success or failure of the school system. From the data that is available from national and state reports, as well as the reauthorization of the No Child Left Behind Act of 2001, public school superintendents focus on how to successfully lead their school systems into the $21^{\text {st }}$ century. 
Using Bolman and Deal’s (2006) Leadership Images Self-Inventory and the Keirsey FourTypes Sorter (1998), this study will explore the relationship between the leadership images of West Virginia superintendents and directed modes of thinking. The research and the findings will have implications for practicing and emerging superintendents and will illustrate implications for further research.

This chapter briefly has introduced the plan to study the leadership image of West Virginia superintendents and directed modes of thinking. Additionally, Chapter 1 has identified the statement of the problem, the research questions, and the significance and limitations of the study. In Chapter 2, a literature review related to the study variables (leadership images and directed modes of thinking) will be presented. Chapter 3 will describe the methodology used in this study and will be comprised of six sections: participants, instrumentations, research design, procedure, data analysis, and a summary. Chapter 4 will present the results of the study. Chapter 5 will present the research findings and discuss conclusions and suggestions for further research. 


\section{Chapter 2}

Literature Review

To understand the leadership behaviors of superintendents as they lead their school systems into the $21^{\text {st }}$ century, a review of related literature provides a context for this study. This chapter reviews the important literature related to leadership images, directed modes of thinking, the superintendent, and instructional leadership. The sequence of the literature review identifies the leadership behaviors of superintendents as it relates to their images and directed modes of thinking.

\section{Leadership Images}

Bolman and Deal argue that leading an organization requires more than being a good manager (2006). Earlier research, completed by Bolman and Deal (1991, 1999, 2003), focuses on structure and people as being the two most important perspectives of a good leader; however, organizations have changed. They are no longer neat packages that follow a structured order. Today, organizations are muddled with new initiatives, such as $21^{\text {st }}$ Century Skills and Technology Integration Specialists, and as a result, they are continuously changing.

Bolman and Deal (2006) suggest that managers today change their focus from structure and human resource to politics and passion. A study of the leadership orientation frames of superintendents and their perceptions about educational change showed that the political and symbolic frames were the most affected by the readiness for change (Frick, 1996). Thus, a study conducted on Indiana public school superintendents identified the human resource frame of leadership as their dominant frame and their most preferred while identifying the political frame as their least preferred frame (Ward, 2006). With ever-changing organizations, the leader must be able to face the changes head on and create a culture of change within the organization. The 
wizard and the warrior are introduced by Bolman and Deal (2006) as the two leadership images that are characteristics of a great leader. Each leadership image represents a model with its own tools and behaviors.

The wizard operates in an environment that brings meaning to the organization. Tools used by the wizard are stories and ceremonies that enable them to bring imagination, creativity, and meaning to the organization (Bolman \& Deal, 2006). On the other hand, the warrior operates in a place of conflict. Tools used by the warriors are wisdom and foresight that enable them to fight as long as necessary to accomplish their mission (Bolman \& Deal, 2006). Leaders may be wizards or warriors; however, great leaders require the characteristics of both (Bolman \& Deal, 2006).

Wizards. "Wizards bring imagination, insight, creativity, vision, meaning, and magic to the work of leadership" (Bolman \& Deal, 2006, p. 21). Thus, the result of the work of wizards brings meaning to the organization while producing results that improve the organization. Based on the research of Bolman and Deal (2003, 2006), the wizard aligns with the symbolic frame. The symbolic frame is one of the four organizational frames defined by Bolman and Deal. The symbolic frame focuses on how leaders make sense of what is happening in the organization. Symbols are used to make powerful statements about the organization. Bolman and Deal (2003) base the symbolic frame on the following assumptions:

1. What is most important is not what happens, but what it means.

2. Activity and meaning are loosely coupled; events have multiple meanings because people interpret experience differently.

3. In the face of widespread uncertainty and ambiguity, people create symbols to resolve confusion, increase predictability, find direction, and anchor hope and faith. 
4. Many events and processes are more important for what is expressed than what is produced. They form a cultural tapestry of secular myths, heroes and heroines, rituals, ceremonies, and stories that help people find purpose and passion in their personal and work lives.

5. Culture is the glue that holds an organization together and unites people around shared values and beliefs (p. 242).

The symbolic leader is able to bring enthusiasm and dedication to the organization through the use of charisma and style. Results from a study completed by Bolman and Deal (1991) on college presidents, higher education administrators, and school administrators show that college presidents were more likely to use the symbolic frame than higher education administrators and school administrators.

Bolman and Deal (2006) identify five traits of the wizard that capture the essence of wisdom. The five traits include: wizards are wise; wizards embrace foibles and folly; wizards are intimately connected with soul; wizards are magical; and wizardry is within reach (Bolman \& Deal, 2006). First, wizards are wise to be able to look beyond the day to day activities of an organization and see the bigger picture. For example, the wizard image of the superintendent is able to address daily personnel issues, while at the same time is able to be creative in directing funds to secure personnel positions in the future. Second, wizards view mistakes as learning experiences. In confronting the service personnel organization, the superintendent quickly learns the best approach to use when hoping to come to a consensus. Third, it is the soul of the wizard superintendent that brings compassion and support to the employees of the school system. Initiating policies and procedures that support employees who have lost loved ones, who are caring for elderly parents, or who have experienced a family tragedy provide many options that 
are appreciated by the employees and speaks of the wizard's soul. Next, wizards are magical. Instead of purchasing ads in the newspaper that have the school system's logo, superintendents may choose to highlight students, parents, teachers, and programs in the ads. As school systems move into the $21^{\text {st }}$ century, all ads in the newspaper may focus on how technology is used in the schools to support $21^{\text {st }}$ Century Skills. The ads are catchy and begin to create exciting conversation among community members, faculty, students, and parents. Finally, wizardry is within reach. Superintendents are forced to make decisions every day. Some decisions have to be made quickly without time for a lot of thought. It is these times that superintendents have to look deep within themselves and make the best decisions based on what lies within. Superintendents reach for common sense and what they believe in to help make these decisions. Once the decisions are made, the superintendents are able to inspire others to follow their beliefs.

Warriors. "Warriors believe that managers and leaders live in a world of conflict and scarce resources” (Bolman \& Deal, 2006, p. 21). Thus, warriors battle conflict and competition in order to meet the goals of the organization. Based on the research of Bolman and Deal (1991, 1999, 2003, 2006), the warrior aligns with the political frame. The political frame is one of the four organizational frames defined by Bolman and Deal. The political frame puts politics at the heart of decision-making. The leader of the organization understands the workings of the political arena and the importance of aiming to pacify stakeholders. Bolman and Deal (2003) base the political frame on the following assumptions:

1. Organizations are coalitions of diverse individuals and interest groups.

2. There are enduring differences among coalition members in values, beliefs, information, interests, and perceptions of reality.

3. Most important decisions involve allocating scarce resources - who gets what. 
4. Scarce resources and enduring differences make conflict central to organizational dynamics and underline power as the most important asset.

5. Goals and decisions emerge from bargaining, negotiation, and jockeying for position among competing stakeholders (p. 186).

The political leader spends time networking and negotiating in order to move the organization forward. Results from a study completed by Bolman and Deal (1991) on college presidents, higher education administrators, and school administrators show that people who are more adept in understanding and using the political frame are perceived by their colleagues, superiors, and subordinates as better managers and leaders. Research (Dowd, 1991) on school superintendents’ perceptions of conflicts and how they deal with them discovered that the political frame was the most used. Also, research (Hughes, 1992) indicates that superintendents are knowledgeable about the political frame and utilized this knowledge to establish relationships with board of education members.

According to Bolman and Deal (2006), warriors are successful because of four strong components: heart, mind, skill, and weapons. These key components contribute to the warrior's ability to march forward in order to accomplish the goals of the organization.

The first component is a heart filled with passion, courage, and persistence that epitomizes the warrior’s commitment to the organization (Bolman \& Deal, 2006). The superintendents’ passion for their school systems may be portrayed by relentless actions that strive to keep the schools immaculate by ensuring that all repairs are made, the grounds are groomed, and the buildings are kept up to date. Also, superintendents display the courage and persistence needed to attack areas in their systems that need improvement. For example, superintendents want to create $21^{\text {st }}$ century classrooms; however, employing highly qualified 
teachers and purchasing technology are not always easy tasks. Being able to find the right people and doing what it takes to hire the right people requires persistence and courage. Furthermore, securing funds to purchase technology may require negotiating with board members and partners in education. Thus, collectively passion, courage, and persistence reflect the personality of the leader and ultimately the personality of the organization.

The second key component of the warrior is the mind. First, the mind focuses on the desires of the leader (Bolman \& Deal, 2006). The superintendents, serving as leaders, are instrumental in developing the goals for the school system. The goals support the vision of the superintendents. Second, once the goals are established, the superintendents must create plans to achieve the goals (Bolman \& Deal, 2006). Superintendents in West Virginia work collectively with stakeholders in order to develop a five-year strategic plan for school systems. The plans provide an outline of steps that need to be taken to accomplish the goals of the school systems. Third, while working through the plans, the superintendents may experience difficulties, yet at the same time, they may also encounter opportunities. During these times, superintendents should demonstrate flexibility (Bolman \& Deal, 2006). Next, Bolman and Deal (2006) state, "Passion in leaders and warriors may be vital but dangerous" (p. 67). The passion of the warrior may create emotions that could destroy the warrior. The emotions of the superintendents may interfere with making the best decision for the school systems. For example, superintendents need to determine which battles to fight and which battles to accept (Bolman \& Deal, 2006). Looking at the big picture enables superintendents to prioritize what is worth fighting for and what is not.

The third critical component of the warrior is skill. Skill, according to Bolman and Deal (2006), consists of intuition, making friends and enlisting allies, rallying the troops, as well as 
enlisting friends and buying off enemies (p. 57). Superintendents at times may find it lonely in the top position; however, there are central office staff and principals who work closely with them. These support staff may be empowered by superintendents to help keep the system running smoothly. Superintendents show their support by delegating responsibilities to these staff members in order to make them an integral part of the organization. The superintendents need the intuitive skills to be able to determine which staff members are loyal, supportive, and trust worthy. Working collectively, the superintendents and support staff are able to provide a clear direction for other members of the organization and the community to follow.

The last component vital to the warrior is the weapon. According to Bolman and Deal (2006), position, organization, resources, and allies are powerful tools for the warrior. In school systems, the position of power is held by superintendents. School organizations, professional staff, service personnel staff, parents, students, and community members are strong supportive forces that may be helpful or harmful to superintendents. The support received from these key people help superintendents fight the war with their allies. For example, superintendents may be searching for support to pass an excess levy that has opposition from a specific community group. Utilizing the resources available from supporters assists superintendents on the battlefield.

Research, provided by Bolman and Deal (1991), shows that for leadership effectiveness, the symbolic frame (where the wizard lives) is a predictor; whereas, the political frame (where the warrior lives) is a significant predictor of success as both leader and manager. Thus, the wizard and warrior are both components for effective leadership. "Leaders who balance their inner warrior and wizard can provide leadership that makes a real and positive difference” (Bolman \& Deal, 2006, p. 7). 


\section{Directed Modes of Thinking}

Since the publication of A Nation at Risk (National Commission on Excellence in Education 1983), educational leaders have worked to improve the educational system in the United States. Since this report, there has been a strong focus on the mathematics, science and other core subjects; however, Daniel H. Pink (2006) argues today that America is moving away from the Information Age to the Conceptual Age. He states that the left brain, which is associated with sequential, logical, and analytical thinking, ruled during the Information Age (Pink, 2006). On the other hand, the right brain, which is associated with inventive, empathetic, and meaningful thinking, is needed to rule in the Conceptual Age. Zhao (2007), the University Distinguished Professor of Education at Michigan State, supports the work of Pink. He concurs that as we move into the Conceptual Age, the "right brain” is what matters (Zhao, 2007). As individuals navigate through their lives, some are logical, sequential, and analytical. These individuals may become accountants, engineers, and lawyers and may be referred to as LDirected Thinking (Pink, 2006). Other individuals may navigate through their lives being holistic, simultaneous, and aesthetic. These individuals may become inventors, entertainers, and counselors and may be referred to as R-Directed Thinking (Pink, 2006). According to Pink (2006), traits associated with L-Directed Thinking were commonly shared by leaders in the United States; thus, it is the traits associated with R-Directed Thinking that is inspiring a change in $21^{\text {st }}$ century leadership.

In recent years, other countries such as India and China have educated individuals to become engineers and other "left brain” professionals (Pink, 2006). These professionals are securing jobs in the United States for lower wages than Americans who held the jobs previously. Based on Zhao’s (2006) research, even though the schools in the United States produce qualified 
professionals, United States businesses will send their jobs to other countries where they can pay similarly qualified professionals for less. If individuals from other countries are able to take these “left brain” jobs from Americans, then Americans must create new skills for new jobs. Pink (2006) suggests that they use skills associated with R-Directed Thinking such as building relationships rather than carrying out transactions, accept challenges as opposed to solving routine problems, and synthesize the big picture instead of analyzing a small part. Once again, Zhao supports Pink’s thinking. Zhao (2006) believes that educators today cannot squelch the imagination and creativity of the American students. School systems cannot teach to a test and not allow for students to be able to problem solve and work collaboratively to develop higher level order thinking skills. The leaders of school systems today must be able to prepare students to be able to compete globally.

Pink (2006) identifies six human attributes that individuals will need to move successfully into the Conceptual Age. The six attributes include: design, story, symphony, empathy, play, and meaning (Pink, 2006). These attributes will contribute to the development of a whole new mind. Those who master this concept will do extremely well; whereas, others who do not will move slowly and unsuccessfully into the future (Pink, 2006).

The first attribute is design. Pink (2006) encourages moving from a functional design to a design that is not only functional but also offers beauty and is emotionally engaging. Leaders who are able to create small changes can offer a more appealing and aesthetic product. For example, when constructing new chemistry classrooms the school superintendents may work with architects to design chemistry laboratories for the students as opposed to the traditional classrooms that have the desks in the front of the room and the lab tables in the back of the room. The second attribute is story. Pink (2006) advises that individuals move away from regurgitating 
information and data and move toward using communication skills to explain the narrative. Stories allow for individuals to express their emotions and thoughts which are not characteristic of the "left brain." Leaders may use stories to explain changes are occurring in organizations. In school systems, superintendents may explain the history as to why teaching positions are being eliminated for the next school year as opposed to just telling teachers that they will not have a job. The third attribute is symphony. Symphony focuses on looking at the big picture and being able to put all the pieces together (Pink, 2006). While studying how the pieces are put together in the big picture, individuals are able to be visionary. They are able to look beyond what is right in front of them. For example, when superintendents inform teachers that their teaching positions are being eliminated they may provide alternatives to the teachers based on the teachers' other areas of certification. Networking among the pieces provides alternative relationships which eliminate working in isolation. The fourth attribute is empathy. Often times, mathematicians are referred to as black and white thinkers. Their answers are either right or wrong; there is no grey area. The attribute of empathy eliminates this kind of thinking. Empathy, according to Pink (2006), in a world of analytic tools, must demonstrate caring and compassion. As superintendents inform teachers of decisions that are detrimental to their employment, if skills associated with R-Directed Thinking are used then a caring attitude is displayed. The fifth attribute is play. In the Conceptual Age, Pink (2006) believes that in work and in life, we all need to play. He lists humor and joyfulness as characteristics of play. In the work environment, play allows for sharing a laugh and being a unified force in an organization. Research (Pink, 2006) has shown that understanding and appreciating humor are "right brain” activities. School superintendents may plan retreats for their administrative teams that allow for not only professional growth but allow for team building and camaraderie. The final attribute is 
meaning. Meaning brings a purpose to everything we do. Pink (2006) recommends that individuals and businesses begin the search for meaning by taking spirituality and happiness seriously. Today, as school systems prepare students to be $21^{\text {st }}$ century learners, superintendents must be able to explain the significance of this initiative to the stakeholders. Student competence in $21^{\text {st }}$ Century Skills not only helps schools meet adequate yearly progress but also prepares students to be able to compete globally. School systems meeting adequately yearly progress should celebrate this success. School leaders must recognize, thank, and celebrate this challenging accomplishment with the faculty and staff.

As the Conceptual Age approaches, Pink (2006) believes that the six attributes: design, story, symphony, empathy, play, and meaning must be nurtured in all of us. "There will be plenty of work not just for inventors, artists, and entrepreneurs but also for an array of imaginative, emotionally intelligent, right-brain professionals, from counselors to message therapists to schoolteachers to stylists to talented salespeople” (Pink, 2006, pp. 246-247).

Pink (2006) concludes his research by stating that our future in the Conceptual Age will depend on the answers to the following three questions.

1. Can someone overseas do it cheaper?

2. Can a computer do it faster?

3. Are we offering something that satisfies the nonmaterial, transcendent desires of an abundant age? (p. 245).

According to Pink (2006), it is the right brainers who will rule the future because they will be able to meet the challenges presented by these three questions.

Zhao answers these three questions in his research. In essence, Zhao takes us past Pink 
as he relates the answers to these three questions to the educational system in the United States. Initially, Zhao (2007) believes that the No Child Left Behind Act of 2001 (NCLB) has failed to meet the educational goals of the United States. In his research (Zhao, 2007), it is stated that 35 states reported that students received higher scores in English/Language Arts than the previous year, and 36 states reported similar results in math. The other states reported the test scores as dropping, staying the same, or identifying some other reason. Explanations given by the report for the improvement include: the students learned more, the students developed better testtaking skills, cheating, changes in tests, and normal fluctuations in grades (Zhao, 2007). The No Child Left Behind Act of 2001 has forced school systems to focus on standardized testing and as a result, have hindered the most important and sought-after commodity in the $21^{\text {st }}$ century creativity. Zhao (2007) is arguing for an educational system that does not confine students to a limited number of subjects and a system that does reach out to all students.

Zhao’s (2007) research contains information about multiple intelligences. For many years, and still today, much of the testing done in schools concentrates on verbal and mathematical skills. Students who do not excel in these areas have been identified as academically challenged. Students' weaknesses in these two areas may have affected their chances for scholarships and admittance into colleges and universities. Zhao (2007) found that only about 20 percent of an individual's IQ contributes to a successful career. It is here that Zhao (2007) supports Pink on the importance of other intelligences as we move into the $21^{\text {st }}$ century. "Left brain" thinking is no longer sufficient; what really matters is "right brain" thinking.

Can someone overseas do it cheaper? According to Zhao (2007), other countries, such as China and India, are working for United States' businesses in their countries at lower costs. As 
long as there is a focus on math and science in these countries, these entrepreneurial activities will continue to occur. To remain competitive, Zhao (2007) believes the United States must create new and innovative businesses. These new jobs will demand different types of skills and talents.

Can a computer do it faster? In some cases it may, and in other cases it may not; however, if it cannot, setting higher standards for our students and requiring accountability from our schools is appropriate in order to get the job done. The Council on Competitiveness 2006 (Zhao, 2007) revealed that the United States has remained competitive with other countries over the last two decades. The United States has excelled in scientific research, entrepreneurial activity, and worker productivity (Zhao, 2007). Educators are cognizant that math and science are important to the curriculum yet school systems must be able to add another dimension that develops other talents in our students.

Am I offering something that satisfies the nonmaterial, transcendent desires of an abundant age? School systems in the world are attempting to meet the challenge of a $21^{\text {st }}$ century education. Zhao’s (2007) research indicates that school systems are teaching foreign languages to elementary students as part of exposing them to languages and cultures of other countries at an early age. School systems have become creative by using technology and writing grants in order to design early language programs. Beginning with the school year 20082009, there are five school systems in West Virginia that will be offering Chinese to their students; however, Ohio County Schools is the only school system in West Virginia to offer a K12 Spanish program. Curriculum changes being adopted by other countries such as China, South Korea, Sinagpore, and Japan include: advocating individualization, encouraging creativity, reducing the power of testing, reforming assessment, offering more courses outside traditional 
disciplines, requiring community service, starting a foreign language in grade 3 , creating selfdriven citizens, teaching critical and creative-thinking skills, enhancing emotional education, enhancing local autonomy, and requiring schools to have an international partner (Zhao, 2007).

Globalization is being addressed universally. How is the United States facing the challenge? How is West Virginia facing the challenge? Educational leaders must work together to provide a $21^{\text {st }}$ century education for our students. According to Zhao (2007), educational leaders must become less obsessed with test scores and pursue the most popular commodity in the $21^{\text {st }}$ century - creativity. Over the last twenty years, creativity has been connected to functions of the brain (Herrmann, 1981). Research (Bruer, 1999; Herrmann, 1981; Jensen, 2005; Lynch, 1986; Pink, 2006; Zhao, 2007) reports that left brain thinking or L-Directed Thinking is associated with logic, and right brain thinking or R-Directed Thinking is associated with creativity. Herrmann (1981) further indicates that in the majority of people both the left brain and the right brain work together, but one clearly takes the lead. As indicated by Pink (2006), $21^{\text {st }}$ century leaders are able to complement L-Directed Thinking with R-Directed Thinking. Herrmann (1981) strongly supports the fact that creativity is whole-brained, the left brain and the right brain working together.

A study of the relationship of left and right brain dominance to leadership styles of public school superintendents in Arkansas indicated that Arkansas superintendents are predominantly left brained, and they are predominantly characterized by an authoritative leadership style (Ross, 1990). Similarly, a study done in Texas revealed that the superintendents were predominantly left brained and controlling (Scott-Soler, 1991). Furthermore, the study (Scott-Soler, 1991) indicated that female superintendents revealed a holistic brain dominance profile. Another study (Norris, 1984) done in Tennessee closely resembles the study done in Texas. The male 
superintendents were strongly oriented toward left brain and highly rated as technical, and the female superintendents were more characteristically whole brained (Norris, 1984).

Researchers have conducted studies on the relationship between right brain and left brain characteristics and leadership styles and images. A study done in 1997 was designed to examine the relationship between brain hemispheric characteristics and leadership style of school superintendents in West Virginia (Farmer, 1997). The study revealed that the superintendents who were predominantly right brain had significantly higher Consideration (people oriented) scores than superintendents who were predominantly left brain (Farmer, 1997). Another finding in the study was that 17 superintendents were predominantly left brain and 11 superintendents were predominantly right brain (Farmer, 1997).

\section{The Keirsey FourTypes Sorter}

In 1920, a Swiss psychoanalyst Carl Jung invented the term “psychological types” to indicate that people are different in fundamental ways, even though they all basically have the same inner instincts (Keirsey \& Bates, 1984). In 1950, Isabel Myers read Jung’s book on “psychological types” and with the help of her mother, Katheryn Briggs, created the MyersBriggs Type Indicator (Keirsey \& Bates, 1984). The type theory developed from the works of Jung, and of Myers and Briggs. The Myers-Briggs Type Indicator is a questionnaire about preferences designed to help people determine their personality types. The Myers-Brigg Type Indicator is the most commonly used psychological instrument in the world (Baron, 1998). The instrument comes in fourteen different languages, and more than ten million copies have been sold by the early 1990s (Baron, 1998). Also, the Myers-Briggs Type Indicator is a registered trademark of Consulting Psychologists Press, Inc. (Baron, 1998).

The Myers-Briggs list four pairs of opposite preferences (Baron, 1998). The four 
pairs of opposite preferences are: Extraverting (E) and Introverting (I), Sensing (S) and iNtuiting

(N), Thinking (T) and Feeling (F), and Judging ( $\mathrm{J})$ and Perceiving (P). Taking one preference

from every pair will form the four-letter code that represents each person's type. For example, if

a person prefers Introverting, iNtuiting, Feeling, and Perceiving their type is INFP. Collectively

there are sixteen different types. The descriptions of the sixteen Myers-Briggs Types are

illustrated in Figure 1.

Figure 1

Descriptions of the Sixteen Myers-Briggs Types*

\section{Sensing Judging Types (SJ): Duty Seekers}

SJs are motivated by a need to be useful and of service. They like to stick to the standard ways of doing things and value the traditions, customs, and laws of society.

\begin{tabular}{|c|c|}
\hline ESTJ & ESFJ \\
\hline $\begin{array}{l}\text { Outgoing, energetic, and dependable. } \\
\text { Efficient, organized, and decisive. Likes } \\
\text { administrating and being in charge. Excellent } \\
\text { at organizing and deciding policies and } \\
\text { procedures. Assertive, out-spoken and direct. } \\
\text { Focuses on solving problems. Responsible, } \\
\text { hardworking, and goal-oriented. Consistent, } \\
\text { pragmatic, and logical. }\end{array}$ & $\begin{array}{l}\text { Enthusiastic, sociable, and engaging. Likes to } \\
\text { be needed and appreciated. Personable, } \\
\text { sympathetic, and cooperative. Like being } \\
\text { helpful, active in service organizations. } \\
\text { Trustworthy, loyal, and responsible. Values } \\
\text { harmony and shows love in practical ways. }\end{array}$ \\
\hline ISTJ & ISFJ \\
\hline $\begin{array}{l}\text { Reserved, persevering, loyal, and careful. } \\
\text { Systematic, organized, and focused on the } \\
\text { facts. Hardworking, thorough, and good at } \\
\text { follow-through. Down-to-earth, pragmatic, } \\
\text { and trustworthy. Honor their commitments. } \\
\text { Do what is "right" and expect the same of } \\
\text { others. Calm and consistent in crisis. }\end{array}$ & $\begin{array}{l}\text { Conscientious, trustworthy, and cooperative. } \\
\text { Loyal, dependable, and self-disciplined. } \\
\text { Strong work ethic, completes tasks on time. } \\
\text { Excellent memory for details. Quietly friendly, } \\
\text { thoughtful, and reserved. Often works behind } \\
\text { the scenes helping others. Modest and } \\
\text { unassuming. Warm, tactful, and gentle. }\end{array}$ \\
\hline
\end{tabular}

\section{Sensing Perceiving Types (SP): Action Seekers}

SPs are motivated by a need for freedom and action. They value and enjoy living in the here and now.

\begin{tabular}{|l|l|}
\hline ESTP & ESFP \\
$\begin{array}{l}\text { Likes risk, challenge, and adventure. Energetic } \\
\text { and constantly on the go. Lives life to the }\end{array}$ & $\begin{array}{l}\text { Caring, generous, cooperative, and enjoys } \\
\text { helping others. Friendly, gregarious, energetic, }\end{array}$ \\
\hline
\end{tabular}




\begin{tabular}{|c|c|}
\hline $\begin{array}{l}\text { fullest. Alert, confident, and persuasive. Can } \\
\text { be outrageous, direct, and impulsive. } \\
\text { Competent, resourceful, and responds well to } \\
\text { crises. Realistic, pragmatic, and matter-of-fact. } \\
\text { Skillful negotiator. }\end{array}$ & $\begin{array}{l}\text { vivacious, and charming. Often the life of the } \\
\text { party. Tolerant and accepting of self and } \\
\text { others. Has practical common sense. } \\
\text { Accentuates the positive. Enjoys new } \\
\text { experiences and has zest for life. }\end{array}$ \\
\hline ISTP & ISFP \\
\hline $\begin{array}{l}\text { Prefers action to conversation. Likes } \\
\text { adventure and challenge. Does well in crisis. } \\
\text { Enjoys working with tools, machines, and } \\
\text { anything requiring hands-on skills. } \\
\text { Resourceful, independent, and self-determined. } \\
\text { Logical, realistic, and practical. Reserved, } \\
\text { detached, curious observer. Storehouses of } \\
\text { information and facts. }\end{array}$ & $\begin{array}{l}\text { Gentle, loyal, and compassionate. Appears } \\
\text { reserved and unassuming. Quietly does things } \\
\text { for others. Patient, accepting, and } \\
\text { nonjudgmental. Has a live-and-let-live } \\
\text { attitude. Sensitive to conflicts and } \\
\text { disagreement. Has little need to dominate or } \\
\text { control others. }\end{array}$ \\
\hline
\end{tabular}

\section{Intuiting Thinking Types (NT): Knowledge Seekers}

NTs are motivated by a need to understand the world around them. They value competency and the powers of the mind.

\begin{tabular}{|l|l|}
\hline ENTJ & ENTP \\
$\begin{array}{l}\text { Confident leader who likes to be in charge. } \\
\text { Decisive and ambitious. Likes intellectual } \\
\text { exchange. Ingenious and resourceful in } \\
\text { solving complex problems. Innovative, } \\
\text { analytical, and logical. Self-determined and } \\
\text { independent. Aspires to be the best at } \\
\text { whatever (s)he does. }\end{array}$ & $\begin{array}{l}\text { Outspoken and thrives on challenge and } \\
\text { debate. Enthusiastic, charming, gregarious, } \\
\text { and witty. Values freedom and independence. } \\
\text { Innovative, enterprising, and resourceful. } \\
\text { Spontaneous and impulsive. Risk-taker who is } \\
\text { alert to all possibilities. Inquisitive and } \\
\text { curious. }\end{array}$ \\
\hline INTJ & INTP \\
$\begin{array}{l}\text { Independent and individualistic. Has great } \\
\text { insight and vision. Skilled in creating theories } \\
\text { and systems. Drives self and others toward } \\
\text { goals and self-improvement. Ingenious and } \\
\text { creative problem-solver. Organized, } \\
\text { determined, and good at follow-through. } \\
\text { Responsible, reserved, and private. }\end{array}$ & $\begin{array}{l}\text { Analytical and brilliant. Conceptual problem- } \\
\text { solver and original thinker. Idiosyncratic and } \\
\text { nonconforming. Values precision in thought } \\
\text { and language. Notices inconsistencies, } \\
\text { contradictions, and logical flaws in others' } \\
\text { thinking. Independent, curious, and insightful. } \\
\text { Private, aloof, and introspective. }\end{array}$ \\
\hline
\end{tabular}

\section{Intuiting Feeling Types (NF): Ideal Seekers}

NFs are motivated by a need to understand themselves and others. They value authenticity and integrity and strive for an ideal world.

\begin{tabular}{|l|l|}
\hline ENF J & ENFP \\
$\begin{array}{l}\text { Friendly, charming, enthusiastic, and socially } \\
\text { active. Persuasive speaker and inspiring, } \\
\text { charismatic leaders who motivates others. }\end{array}$ & $\begin{array}{l}\text { Warm-spirited, helpful, accepting, and } \\
\text { compassionate. Full of enthusiasm and new } \\
\text { ideas. Values freedom and autonomy. Good }\end{array}$ \\
\hline
\end{tabular}




\begin{tabular}{|l|l|}
\hline $\begin{array}{l}\text { Empathic, warm, helpful, and supportive. Can } \\
\text { idealize people and relationships. Responsible, } \\
\text { conscientious, and goal-oriented. Diplomatic } \\
\text { and good at promoting harmony. }\end{array}$ & $\begin{array}{l}\text { at communicating and inspiring action. } \\
\text { Creative, spontaneous, positive, and fun- } \\
\text { loving. Individualistic, insightful, and } \\
\text { perceptive. }\end{array}$ \\
\hline INFJ & $\begin{array}{l}\text { INFP } \\
\text { Sensitive, deep, and sometimes mystical. } \\
\begin{array}{l}\text { Single-minded regarding personal values and } \\
\text { convictions. Has a rich inner life, and values } \\
\text { person integrity. Creative, original, and } \\
\text { idealistic. Reserved, gentle, and } \\
\text { compassionate. Enjoys solitude, yet has a } \\
\text { strong need for harmony. Conscientious, } \\
\text { determined, and persevering. }\end{array}\end{array}$ \\
$\begin{array}{l}\text { Dentle. Dislikes rules, orders, schedules, and } \\
\text { deadlines. Likes learning and being absorbed } \\
\text { in own projects. Has passionate convictions, } \\
\text { and drive for ideal. Sets high standards for } \\
\text { self. Idealistic, sensitive, and creative. Can be } \\
\text { reserved and contemplative. }\end{array}$ \\
\hline
\end{tabular}

*Adapted from Baron, 1998.

In 1978, the second theory, temperament, was developed by an American clinical psychologist, David Keirsey (Baron, 1998). As he studied the Myers-Briggs descriptions of the sixteen types, he discovered temperament patterns that he had been researching. As a result, he correlated his four temperaments with the sixteen types of the Myers-Briggs system. Today, the type and temperament theory complement each other to provide valuable information. According to Keirsey and Bates (1984), “One’s temperament is that which places a signature or thumbprint on each of one's actions, making it recognizably one's own” (p. 27). The Jung/Myers-Briggs type theory and the Keirsey temperament theory together provide a deep approach to studying personality and temperaments.

In the Myers-Briggs system, the four temperament themes are called: Sensing Judging (SJ), Sensing Perceiving (SP), iNtuiting Thinking (NT), and iNtuiting Feeling (NF) (Baron, 1998). The Sensing Judging is motivated to be responsible to their social group, whether it be family, the workplace, or the community. The Sensing Perceiving values living for the moment. The iNtuiting Thinking thirsts for knowledge and competency. The iNtuiting Feeling needs to understand themselves and others. 
Keirsey uses four Greek gods to represent the temperaments: Apollo, Dionysus, Prometheus, and Epimetheus (Keirsey \& Bates, 1984). "Myth has it that Apollo was commissioned to give man a sense of spirit, Dionysus to teach man joy, Prometheus to give man science, and Epimetheus to convey a sense of duty” (Keirsey \& Bates, 1984, p. 29). Clearly, each of these gods differs from each other and has his own followers. Similarly, each temperament has its own characteristics and its own followers.

The Dionysian temperament aligns with the Sensing Perceiving (SP) in the Myers-Briggs temperament system (Keirsey \& Bates, 1984). Both temperaments are impulsive and live for today (Keirsey \& Bates, 1984). There are no daily agenda and schedules to follow. The SP is more process oriented than driven to work (Keirsey \& Bates, 1984). Daily activities bring a sense of accomplishment and completeness to life. Additionally, the SP is loyal to peers and defends them against any attacks (Keirsey \& Bates, 1984). The sense of protecting others in the group is important to the SP. Defined as a realist, the SP does not find the need to create policies, goals, objectives, and action steps to live in a care free world (Keirsey \& Bates, 1984). Since the SP is not goal oriented, events with hardship, worry, and torture are not experienced; thus, the Dionysian SP does establish goals. If achieving these goals becomes too difficult, then fleeing usually occurs.

Keirsey (1998) later went on to define the Dionysian as the Artisan. Artisans focus on objects that are useful in daily life. The utilitarian character of the Artisans causes them to welcome problems others may avoid (Keirsey, 1998). They concentrate on what is actually happening in the world.

The managerial characteristics of the Dionysian SP Artisan as defined by Keirsey (1998) are listed below. 
1. A natural negotiator;

2. A troubleshooter;

3. Flexible;

4. Reluctant to pay attention to theory;

5. Lives in the moment;

6. Verbalizes appreciation;

7. Encourages others;

8. A risk taker; and

9. Needs support services.

The Epimethean Temperament aligns with the Sensing Judging (SJ) in the Myers-Briggs temperament system (Keirsey \& Bates, 1984). Both temperaments exist to be useful to the social organizations to which they belong (Keirsey \& Bates, 1984). They do not depend upon the organization for their survival; thus, they are there to help others. According to Keirsey and Bates (1984), they serve as the parents. The role of the parent serves as the overseer of other members of the organization, thus creating levels of hierarchy.

The myth of Epimetheus, brother of Prometheus is as follows. "Prometheus advised his brother Epimetheus not to accept any gifts from their father Zeus. Prometheus followed his own advice and refused to marry the beautiful women Zeus fashioned for him. Epimetheus, following his brother's lead, did likewise when Zeus then offered Pandora to him - at which point Zeus's wrath erupted in full fury. Epimetheus, frightened by Zeus’s terrible punishment of Prometheus, hastened to reconsider his decision and accepted Pandora, even though he was fully aware of the dangers presented by this gift, the most beautiful woman ever created! Soon Pandora gave in to curiosity and investigated the golden chest she carried with her from 
Olympus, but which she had been forbidden by Zeus to open. But Epimetheus stood by his wife even after she raised the lid of the forbidden box, letting escape all manner of ills onto mankind: old age, labor, sickness, insanity, vice - and passion. Epimetheus suffered their stings as did Pandora, but never did he abandon her; rather, he accepted his fate in good conscience, seeking out the should's and ought's which would guide him as a shield against these evils now abroad in the world” (Keirsey \& Bates, 1984, pp. 39-40).

Keirsey (1998) later went on to define the Epimethean as the Guardian. Guardians watch and protect the activities and people in an organization. The concrete cooperative character of the Guardians causes them to be very clear in their speech and work together with others in implementing goals (Keirsey, 1998). They have a sense of responsibility to protect the world.

The managerial characteristics of the Epimethean SJ Guardian as defined by Keirsey (1998) are listed below.

1. A sense of social responsibility;

2. Creates stability in the organization;

3. A decision-maker;

4. A steady worker;

5. Runs efficient meetings;

6. Impatient with projects;

7. Pursues a perfect organization;

8. Competitive;

9. May not handle employees in a professional manner; and 10. Excellent at carrying out plans.

The Promethean Temperament aligns with the Intuiting Thinking (NT) in the Myers- 
Briggs temperament system (Keirsey \& Bates, 1984). In order to create man to be more like the gods, Prometheus gave him fire (Keirsey \& Bates, 1984). The possession of fire created a power over nature for mankind. It is the desire of power that sets the Promethean apart from others (Keirsey \& Bates, 1984). Both temperaments are mesmerized by power, not power over people, but power over nature (Keirsey \& Bates, 1984). Today, they would be defined as scientists. Fittingly, the NT strives for perfection and is very self-critical (Keirsey \& Bates, 1984). All projects are completed with self-induced pressure for perfection. As a result, the NT is in a constant state of torment and criticism in the pursuit of competence. The sense of being on the edge of failure may interfere with the NT's ability to lead forward (Keirsey \& Bates, 1984).

The NT may send two contradictory messages to other people: very little is expected from others and others are expected to achieve the same standards of work ethic (Keirsey \& Bates, 1984). Note, these behaviors do not occur in three other temperaments: Dionysian, Epimethean, Promethean, and Apollonian. These behaviors may affect how other members of the organization work under the NT. Others may work in fear, thinking that their work is not adequate or acceptable, therefore, not allowing for the opportunity of growth and creativity. According to Keirsey and Bates (1984), the NTs live in their work more than any other temperament. The NT does not allow for much idle time for "play."

"The spirit of the NT is caught in the myth of Prometheus, the Greek God who created man from clay. Disappointed in his lifeless sculpture, Prometheus enlisted the help of Minerva. She carried him to heaven where he stole fire from the wheel of the sun. Prometheus applied the stolen fire to the breast of man, giving him life. Prometheus paid for his theft by being 'nailed hard and fast in chains beneath the open sky. A greedy vulture tore at his blackened liver all day, year in and year out. And there was no end to the pain: every cruel frost and freezing winds, his 
liver grew whole again. Prometheus rescued man from ignorance, even though he had to rob heaven to do so. He proclaimed the doctrine of progress for man and secured the gifts of science and technology” (Keirsey \& Bates, 1984).

Keirsey (1998) later went on to define the Promethean as the Rational. The focus of rationals is to study nature. Rationals keep science and the advancement of technology at the forefront of their learning. The utilitarian character of the Rationals is more concerned with their work than pleasing others (Keirsey, 1998). They want to operate an efficient organization.

The managerial characteristics of the Promethean NT Rational as defined by Keirsey (1998) are listed below.

1. Sets rules and regulations;

2. A visionary;

3. Does not express appreciation to subordinates;

4. An architect of change;

5. Unaware of the feelings of others;

6. Responsive to new ideas from colleagues;

7. Excellent decision maker; and

8. Spends time planning.

The Apollonian Temperament aligns with the Intuiting Feeling (NF) in the Myers-Briggs temperament system (Keirsey \& Bates, 1984). Both temperaments strive to have a purpose in life (Keirsey \& Bates, 1984). In other words, meaning in life must exist. Hamlet struggled with the same purpose in life: “To be or not to be” (Keirsey \& Bates, 1984).

The NFs may show signs of mission by being creative in order to attract followers. NFs inhabit the world of writers, psychiatry, counseling, the ministry, and teaching (Keirsey \& Bates, 
1984). The NF works to bring out the best in others (Keirsey \& Bates, 1984). As a leader, the NF would empower others to give them the opportunity to excel.

“Apollo, in Greek mythology, stands as a direct link between the gods and man, giving man a sense of mission, showing man how to continue in his search for the sacred even though he has known the evil of the profane. Apollo was the self-appointed bearer of Truth, and he undertook the task of interpreting for men the will of his father, Zeus. Within Apollo the sense of mission, the cult of the individual, the search for identity existed side by side with untamed lust, the willingness to murder for a cause, the willingness to use priestesses in his rites even at the expense of their sanity and, ultimately, the betrayal of his father, Zeus. In Apollo, side by side, existed the sacred and the profane” (Keirsey \& Bates, 1984, p. 66).

The four Greek gods, Apollo, Dionysus, Prometheus, and Epimetheus represent the characteristics of the four temperaments. Each god gives something different to mankind based on the research by Keirsey and Bates (1984). Apollo gives man a sense of spirit; Dionysus teaches man joy; Prometheus gives man science; and Epimetheus conveys a sense of duty. Again, each temperament is different from each other. The differences contribute to the variations of leadership images and followers.

Keirsey (1998) later went on to define the Appollonian as the Idealist. The focus of idealists is caring for people. Idealists are able to respond to the need of others. The abstract cooperative character of the Idealists is able to use thought and speech to bring peace into the world (Keirsey, 1998). They are positive people.

The managerial characteristics of the Appollonian NF Idealist as defined by Keirsey (1998) are listed below.

1. Focuses on the growth of others; 
2. Enthusiastic spokesman;

3. Values approval;

4. Charismatic management style;

5. Committed to the organization;

6. Turns liabilities into assets;

7. Expresses appreciation;

8. Values appreciation;

9. Responsive to interpersonal transactions;

10. Makes decisions on personal likes and dislikes;

11. Creates a climate of autonomy;

12. Popular with colleagues; and

13. Outstanding in public relations.

In summary, each temperament is unique in traits and character. Figure 2 illustrates the major aspects of the temperaments.

Figure 2

The Traits of Temperament and Character*

\begin{tabular}{|c|c|c|c|c|}
\hline $\begin{array}{c}\text { Communication } \\
\text { Implementation } \\
\text { Character }\end{array}$ & $\begin{array}{c}\text { Concrete } \\
\text { Utilitarian } \\
\text { Artisan } \\
\end{array}$ & $\begin{array}{c}\text { Concrete } \\
\text { Cooperative } \\
\text { Guardian } \\
\end{array}$ & $\begin{array}{c}\text { Abstract } \\
\text { Cooperative } \\
\text { Idealist } \\
\end{array}$ & $\begin{array}{c}\text { Abstract } \\
\text { Utilitarian } \\
\text { Rational } \\
\end{array}$ \\
\hline Language & Harmonic & Associative & Inductive & Deductive \\
\hline $\begin{array}{l}\text { Referential } \\
\text { Syntactical } \\
\text { Rhetorical }\end{array}$ & $\begin{array}{l}\text { Indicative } \\
\text { Descriptive } \\
\text { Heterodox }\end{array}$ & $\begin{array}{l}\text { Imperative } \\
\text { Comparative } \\
\text { Orthodox } \\
\end{array}$ & $\begin{array}{l}\text { Interpretive } \\
\text { Metaphoric } \\
\text { Hyperbolic }\end{array}$ & $\begin{array}{l}\text { Categorical } \\
\text { Subjunctive } \\
\text { Technical } \\
\end{array}$ \\
\hline Intellect & Tactical & Logistical & Diplomatic & Strategic \\
\hline $\begin{array}{l}\text { Directive Role } \\
\text { - } \quad \text { Expressive } \\
\text { - } \quad \text { Reserved } \\
\text { Informative Role } \\
\text { - } \quad \text { Expressive } \\
\text { - } \quad \text { Reserved }\end{array}$ & $\begin{array}{l}\text { Operator } \\
\text { - } \quad \text { Promoter } \\
\text { - } \quad \text { Crafter } \\
\text { Entertainer } \\
\text { - } \quad \text { Performer } \\
\text { - } \quad \text { Composer }\end{array}$ & $\begin{array}{l}\text { Administrator } \\
\text { - } \quad \text { Supervisor } \\
\text { - } \quad \text { Inspector } \\
\text { Conservator } \\
\text { - } \quad \text { Provider } \\
\text { - } \quad \text { Protector }\end{array}$ & $\begin{array}{l}\text { Mentor } \\
\text { - } \quad \text { Teacher } \\
\text { - } \quad \text { Counselor } \\
\text { Advocate } \\
\text { - Champion } \\
\text { - Healer }\end{array}$ & $\begin{array}{l}\text { Coordinator } \\
\text { - } \quad \text { Fieldmarshal } \\
\text { - } \quad \text { Mastermind } \\
\text { Engineer } \\
\text { - Inventor } \\
\text { - } \quad \text { Architect }\end{array}$ \\
\hline
\end{tabular}




\begin{tabular}{|c|c|c|c|c|}
\hline Interest & & & & \\
\hline $\begin{array}{l}\text { Education } \\
\text { Preoccupation } \\
\text { Vocation } \\
\end{array}$ & $\begin{array}{l}\text { Artcraft } \\
\text { Technique } \\
\text { Equipment }\end{array}$ & $\begin{array}{l}\text { Commerce } \\
\text { Morality } \\
\text { Materiel } \\
\end{array}$ & $\begin{array}{l}\text { Humanities } \\
\text { Morale } \\
\text { Personnel } \\
\end{array}$ & $\begin{array}{l}\text { Sciences } \\
\text { Technology } \\
\text { Systems } \\
\end{array}$ \\
\hline \multicolumn{5}{|l|}{ Orientation } \\
\hline $\begin{array}{l}\text { Present } \\
\text { Future } \\
\text { Past } \\
\text { Place } \\
\text { Time } \\
\end{array}$ & $\begin{array}{l}\text { Hedonism } \\
\text { Optimism } \\
\text { Cynicism } \\
\text { Here } \\
\text { Now } \\
\end{array}$ & $\begin{array}{l}\text { Stoicism } \\
\text { Pessimism } \\
\text { Fatalism } \\
\text { Gateways } \\
\text { Yesterday } \\
\end{array}$ & $\begin{array}{l}\text { Altruism } \\
\text { Credulism } \\
\text { Mysticism } \\
\text { Pathways } \\
\text { Tomorrow } \\
\end{array}$ & $\begin{array}{l}\text { Pragmatism } \\
\text { Skepticism } \\
\text { Relativism } \\
\text { Intersections } \\
\text { Intervals } \\
\end{array}$ \\
\hline \multicolumn{5}{|l|}{ Self-Image } \\
\hline $\begin{array}{l}\text { Self-Esteem } \\
\text { Self-Respect } \\
\text { Self-Confidence }\end{array}$ & $\begin{array}{l}\text { Artistic } \\
\text { Audacious } \\
\text { Adaptable } \\
\end{array}$ & $\begin{array}{l}\text { Dependable } \\
\text { Beneficent } \\
\text { Respectable } \\
\end{array}$ & $\begin{array}{l}\text { Empathic } \\
\text { Benevolent } \\
\text { Authentic } \\
\end{array}$ & $\begin{array}{l}\text { Ingenious } \\
\text { Autonomous } \\
\text { Resolute } \\
\end{array}$ \\
\hline \multicolumn{5}{|l|}{ Value } \\
\hline $\begin{array}{l}\text { Being } \\
\text { Trusting } \\
\text { Yearning } \\
\text { Seeking } \\
\text { Prizing } \\
\text { Aspiring }\end{array}$ & $\begin{array}{l}\text { Excited } \\
\text { Impulse } \\
\text { Impact } \\
\text { Stimulation } \\
\text { Generosity } \\
\text { Virtuoso }\end{array}$ & $\begin{array}{l}\text { Concerned } \\
\text { Authority } \\
\text { Belonging } \\
\text { Security } \\
\text { Gratitude } \\
\text { Executive }\end{array}$ & $\begin{array}{l}\text { Enthusiastic } \\
\text { Intuition } \\
\text { Romance } \\
\text { Identity } \\
\text { Recognition } \\
\text { Sage }\end{array}$ & $\begin{array}{l}\text { Calm } \\
\text { Reason } \\
\text { Achievement } \\
\text { Knowledge } \\
\text { Deference } \\
\text { Wizard }\end{array}$ \\
\hline \multicolumn{5}{|l|}{ Social Role } \\
\hline $\begin{array}{l}\text { Mating } \\
\text { Parenting } \\
\text { Leading }\end{array}$ & $\begin{array}{l}\text { Playmate } \\
\text { Liberator } \\
\text { Negotiator }\end{array}$ & $\begin{array}{l}\text { Helpmate } \\
\text { Socializer } \\
\text { Stabilizer } \\
\end{array}$ & $\begin{array}{l}\text { Soulmate } \\
\text { Harmonizer } \\
\text { Catalyst }\end{array}$ & $\begin{array}{l}\text { Mindmate } \\
\text { Individuator } \\
\text { Visionary }\end{array}$ \\
\hline
\end{tabular}

*Adapted from Keirsey, 1998.

The Guardian and Rational overlay Bolman and Deal's concept of the warrior and demonstrate characteristics such as quantitative, logistical, and strategic which are associated with L-Directed Thinking (Keirsey \& Bates, 1984; Keirsey, 1998; Bolman \& Deal, 2003, 2006; Pink, 2006). Whereas, the Artisan and Idealist overlay Bolman and Deal's concept of the wizard and demonstrate characteristics such as qualitative, artistic, and authentic which are associated with R-Directed Thinking (Keirsey \& Bates, 1984; Keirsey, 1998; Bolman \& Deal, 2003, 2006; Pink, 2006).

Keirsey’s (1998) message on leadership is that no matter the temperament makeup of leaders, Guardian, Rational, Artisan, or Idealist, the leaders can be effective. However, leaders should be cognizant of the characteristics of the other temperaments in order to understand their 
own strengths and weaknesses. This understanding also allows leaders to identify the temperament makeup of their followers which can be used to enhance their own leadership styles. According to Keirsey (1998), the characteristics of all four temperaments are imperative to bringing change to the organization. A study (Skarstad, 1994) on teacher leaders in a school revealed the need for each type of Keirsey temperament in order to bring about school change. Additional information associated with gender-specific superintendents in Texas public schools showed that female superintendents have common personal and professional characteristics determined by Keirsey’s temperaments and character types (Collavo, 2002). Another finding shows that knowledge of the Keirsey temperaments may benefit the supporting relationship between leaders and followers (Neundorf, 2007).

\section{The Superintendent}

The position of the school superintendent has been in existence since the late 1830s (Kowalski, 2005). The job responsibilities of the superintendents have evolved and changed over time to meet the demands of an ever-changing world. According to Kowalski (2005), the main focus of superintendents until the twentieth century was to implement the state curriculum and supervise teachers. Furthermore, superintendents were known to fulfill the roles of being managers, democratic leaders, and communicators (Kowalski, 2005; Mintzberg as cited in Shafritz, Ott, \& Jang, 2005). These roles are characteristic of superintendents today. Superintendents continue to find themselves being concerned with creating a vision, setting goals, hiring staff, evaluating and assessing, establishing curriculums, and adapting to organizational changes (Carter, Glass, \& Hord, 1993; Hord, 1990; Lashway, 2002; Petersen, 1999; Rammer, 2007). 
In research provided by Carter, Glass, and Hord (1993), the continuous improvement of school systems is dependent upon active superintendents. Superintendents reach out to teachers, students, parents, and the community in order to be effective. Research (Carter, Glass, \& Hord, 1993; Crowson \& Van Cleve, 1990; Wirt, 1990) indicates that superintendents need to work with boards of education, communicate with stakeholders, mentor administrators, and develop relationships with all people involved with the organization in order to successfully lead the school system. Other researchers (Fullan, 2001; Hersey, Blanchard, Johnson, 1996; Kouzes \& Posner, 2007) support that relationships between leaders and the members of the organization contribute to successful leadership.

Cuban (1998) further indicates that superintendents face three conflicting roles instructional, managerial, and political as they lead their school systems. Each role is necessary and important; however, the manner in which the conflicting roles are handled impacts the success of superintendents. In order to deal with the conflicting roles, superintendents make many decisions throughout the day. These decisions are made based on what is in the best interest of the school system, the superintendent's influence of others, and the mere fact that the superintendent has the power to make the decision. According to Mintzberg (as cited in Shafritz, Ott, \& Jang, 2005), many decisions are made based on rules, norms, and the distribution and authority in the organization.

A recent study released by the American Association of Superintendents' Center for System Leadership reports that today’s superintendents are very happy in their jobs, and 90 percent of those surveyed found their work very rewarding (District Administration, 2007). Paul D. Houston (2007), Executive Director of the American Association of Superintendents' Center for System Leadership, adds that the most critical issue facing superintendents today is that there 
is a changed expectation of how schools must perform (District Administration, p. 14). School systems today are preparing students to be $21^{\text {st }}$ century learners. Decades ago, only the top students in the high school graduating class attended post-secondary education; however, today, graduates must be prepared for post-secondary education or have a skilled trade. Currently, school systems are preparing students for jobs that do not exist today. The curriculum offered to students today must prepare them for jobs of the future brought about by economic globalization and technology.

Superintendents may be able to follow twelve guiding principles identified by Marx (2006) as they prepare to lead their school systems into the $21^{\text {st }}$ century. The twelve guiding principles include:

1. Curiosity, persistence, and genuine interest are the main power sources for futures thinking.

2. Breadth and depth are both important.

3. Leaders connect the dots and seek common ground.

4. There are more than two sides to most issues.

5. The future is not necessarily a straight-line projection of the present.

6. Enlightenment and isolation are becoming opposites.

7. Peripheral vision can help us avoid being blind-sided.

8. A belief in synergy can spark knowledge creation and breakthrough thinking.

9. Collateral opportunity and collateral damage both deserve our attention.

10. Bringing out the best in others is basic.

11. Courage and personal responsibility need to overcome fear and self-pity.

12. The role of strategic futurist is part of everybody’s job (p. 14). 
These principles are helpful to superintendents as they complete the following tasks in their school systems: establish the vision, create the organizational structure, assess and evaluate, and adapt to organizational changes. The completion of these tasks intertwined with the twelve listed principles will help superintendents prepare their school systems for the $21^{\text {st }}$ century.

\section{Instructional Leadership}

Although there is a great deal of information on the impact the principal of a school has on educational outcomes, the information on the impact the superintendent has on educational outcomes is not as extensive (Carter, Hord, \& Glass, 1993; Wallace, 1985). However, as a result of the No Child Left Behind Act of 2001, the superintendent has been forced to focus on instructional leadership. Ultimately, the success of a school system is the responsibility of the superintendent (Glass, 1993; Mintzberg as cited in Shafritz, Ott, \& Jang, 2005). The $21^{\text {st }}$ century superintendent must be able to create an educational framework for the school system in order to prepare students to become $21^{\text {st }}$ century learners (Carter, Glass, \& Hord, 1993; Marx, 2006; Pink, 2006; Zhao, 2007).

According to research completed by Petersen (1999), superintendents identified four attributes to be critical in their ability to be instructional leaders. The four attributes include: possess and articulate an instructional vision, create an organizational structure that supports the instructional vision and leadership, assess and evaluate personnel and instructional programs, and meet the demands of organizational adaptation. "The leader's task is to lead the school community through the potential problems by creating an agreed sense of direction through a vision” (MacNeill, Cavanagh, \& Silcox, 2003, p. 7). As superintendents prepare their school systems to be successful in the $21^{\text {st }}$ century, they face leadership challenges as they address the attributes defined by Petersen. 
The first attribute defined by Petersen (1999) is possession and articulation of an instructional vision. Research by Carter, Glass and Hord (1993) found that having a vision and establishing goals are characteristics of superintendents in effective school districts. These superintendents are experiencing success in their school systems. Creating a vision and establishing goals are also important for the school system's academic success (Carter, Glass \& Hord, 1993; Petersen, 1999). School systems that have a clear and explicit vision have been able to raise test scores for all students (Johnson \& Uline, 2005). Research indicates that creating and communicating an instructional vision, mission and goals are characteristics of superintendents who are effective instructional leaders (Clark, 2004; Marlatt, 2004). Improving student achievement is a goal for superintendents; however, one study done in South Carolina Public School Districts revealed that there was no relationship between the superintendents' leadership behaviors in curriculum and instruction and student achievement (Burnett, 1989). According to Carter, Glass, and Hord (1993), the superintendent must have a vision to move students toward achieving academic goals both in the present and in the future. As part of the vision for the San Antonio school system in Texas, a blueprint was created to identify steps the school system needed to take to ensure that all students came to school ready to learn in order to receive topnotch educational experiences (Superintendents of Bexar County, 1993). Superintendents are able to inspire high school administrators to improve student achievement by developing a plan for change (Bottoms, 2001). The plan for change is one component of the vision of the superintendent.

The vision of the superintendent must be communicated to all members of the school system (Petersen, 1999). Thus, the method to articulate the vision is determined by the superintendent. Based on research (Fullan, 2001; Kouzes \& Posner, 2007) leaders who are able 
to inspire a shared vision successfully meet the challenges of leading their organization into the future.

In previous years, the superintendent of Ohio County Schools held an annual state of the school's address each spring. Those attending the address included the following: board of education members, administrators, curriculum coordinators, guidance counselors, Faculty Senate Chairpersons, Local School Improvement Council representatives, Ohio County Educators Association President, Service Personnel Association President, and Partners in Education. In other words, stakeholders attended the event. Also, invited to the address were all media personnel. The primary goal of the state of the school address is to unveil the instructional vision, mission, and goals of the school system for the next school year. Using this platform, the superintendent inspires a vision of what could be and enables the stakeholders to visualize the exciting possibilities of the future (Bolman \& Deal, 2003, 2006; Clark, 2004; Hersey, Blanchard, \& Johnson, 1996; Keirsey, 1998; Kouzes \& Posner, 2007; Marlatt, 2004; Pink, 2006; Zhao, 2007).

If superintendents possess characteristics associated with wizard and R-Directed Thinking skills, then their state of the school address may take on the following scenario. First, they immediately captivate their audience by addressing them with a charismatic flair. The focus of the superintendents is on all stakeholders within the school community regardless of their status. Before the instructional vision is unveiled, accomplishments achieved during the school year by faculty, staff, and students are recognized. Recognition may be given for achieving high test scores, meeting adequate yearly progress, obtaining school of excellence status, transporting students on school buses without any accidents, or passing an excess levy. Thus, these superintendents have the gift of being able to express their appreciation to their followers which 
supports Kouzes and Posner’s (2007) research about encouraging the heart by showing appreciation. Next, the superintendents unveil the instructional vision, mission, and goals for the organization with self-confidence that causes the stakeholders to agree with the decisions and the direction established by the superintendents. The stakeholders are more apt to follow their leaders because in the address the superintendents focus more on the potentialities of their people than on the development of the school system. These superintendents are genuine in their presentations, and the followers view them as someone worth joining. Upon completion of the address, the superintendents arrange for a musical group from the high school to perform while all those attending may celebrate the current year's accomplishments and the journey ahead. Refreshments are served, and the followers as well as the superintendents are able to network and build bonds among themselves. The address is truly a celebratory ceremony. Hence, the superintendents' outstanding public relation skills allow them to be strong advocates for the school system while communicating their enthusiasm for the instructional vision of the school system.

On the other hand, if superintendents possess characteristics associated with warrior and L-Directed Thinking skills, then they may choose not to hold a state of the school address. Warriors and L-Directed Thinking leaders are visionary leaders; however, they have a difficult time communicating their vision. If they chose to hold an address, it may take on the following scenario.

The unveiling of the instructional vision, mission, and goals for the organization reveals a strategic plan that is familiar to the stakeholders. These superintendents, who are very traditional, are reluctant to change; therefore, familiarity exists in the schedules, routines, and procedures that are presented in the plan. They do, however, have the courage to change. The 
presentation is quick and to the point without redundancy. During the address, the followers are able to recognize that superintendents are hard workers and pay attention to detail because matrices, flow-charts, graphs, and other supplementary information are used to bring clarity and logic to the presentation. In addition, telling stories is used to rally the stakeholders to follow the leader. These superintendents show a great deal of passion for staying the course and not finishing until the goals of the school system are met. The superintendents want their followers to share their passion. Thus, it is the "hard worker" mentality that the superintendents appreciate. They have a difficult time showing appreciation to stakeholders unless they are hard workers. In fact, the superintendents are irritated by those who disregard the standards of the organization. It is the hardest workers that the superintendents, after they have constructed the instructional vision of the school system, allow to take over. As the superintendents constantly focus on the strategies of the organization, they tend to ignore the feelings of their workers. Hence, hosting a social gathering after the state of the school address is not a common occurrence of the superintendents because they have a difficult time creating idle conversation with their followers.

All superintendents (wizards, warriors, L-Directed Thinking, R-Directed Thinking) foster the collaboration and support of their administrative team during the state of the school address. The superintendents want their administrative team to be able to deliver and support the same message they present. Research (Fullan, 2001; Kouzes \& Posner, 2007) supports encouraging leaders to pass on the ownership of the articulation and implementation of the instructional vision, mission, and goals of the organization. The relationships formed between the superintendents and their administrative team enhances the leadership roles of the administrators. 
By initiating team effort, group collaboration, and the empowerment of followers the superintendents enable others to lead (Kouzes \& Posner, 2007).

Research (Bolman \& Deal, 2006; Farmer, 1997; Hermann, 1981; Pink, 2006) suggests that to possess and articulate an instructional vision for school systems preparing for the $21^{\text {st }}$ century the skills associated with wizards, warriors, L-Directed Thinking and R-Directed Thinking are necessary. As school systems require change in order to prepare students to compete globally, superintendents complement their sequential and analytic skills with simultaneous and synthetic skills to inspire the change. The superintendents' awareness of the images and directed modes of thinking allows them to understand the kind of leader they are and what it takes to create change (Lynch, 1986).

The second attribute defined by Petersen (1999) is the creation of an organizational structure that supports the instructional vision and leadership of the superintendent. In creating the organizational structure that supports the instructional vision of the school system, the words and actions of the superintendent must be consistent (Bolman \& Deal, 2006; Kouzes \& Posner, 2007). The superintendent is able to show support of the instructional vision by soliciting the assistance of other members of the organization. Members may include central office administrators and building principals.

Central office administrators are assigned different areas of responsibility which include curriculum and instruction, assessment, special education, student services, and federal programs. The superintendent uses the expertise of these administrators to improve the quality of the instructional programs. In doing so, meetings may be held to discuss the status of the programs. The superintendent is able to guide the administrators through their discussions and nurture their creative skills. Creative leaders are able to inspire others to look at possibilities that 
they never imagined (Bolman \& Deal, 2006). Research (Mitchell \& Tucker as cited in Farmer, 1997) shows that the innovation of followers is closely related to the creativity of the leader. Muller (as cited in Carter, Glass, \& Hord, 1993) found that the competence of superintendents in planning for instruction was the best predictor for district effectiveness.

Building principals are an important group of administrators that work closely with the superintendent in carrying out the instructional vision of the school system. The superintendent knows, based on research, that principals have a direct impact on student achievement (Burnett, 1989; Bottoms, 1991; Rammer, 2007). The principals are able to monitor and evaluate the performance of faculty, staff, and students daily. Meetings occur to allow principals to articulate what is actually happening in the schools with the superintendent. If changes are necessary, then the superintendent is conceptual and visionary in order to reframe what is happening into what might be (Bolman \& Deal, 2006). The superintendent's role is to articulate, model, and monitor the district's goals with the principal to increase student achievement (Pollack et.al. as cited in Carter, Glass, \& Hord, 1993). The superintendent should take every opportunity to show others by their own examples that they are committed to the shared values of the school system (Kouzes \& Posner, 2007).

The third attribute from Petersen's (1999) study is the assessment and evaluation of personnel and instructional programs. Once the instructional vision and the organizational structure are in place, it is imperative that the evaluation of personnel and instructional programs occur. To begin the evaluation process, the superintendent may meet with central office administrators and building principals that are involved with the planning, developing, implementing, and evaluating of instructional initiatives (Bredeson, 1995; Brown \& Hunter, 1986; Hord, 1990; Wallace, 1985). Evaluating programs directly related to student achievement 
is the responsibility of superintendents (Hord, 1990; Wallace, 1985). The superintendent must be creative in collaborating with administrators to assist in the evaluation process of the instructional programs (Wallace, 1985). The superintendent and the administrators analyze and synthesize all the factors contributing to effectiveness of personnel and instructional programs.

Also, school visits provide the superintendent with first-hand knowledge on what is happening in the schools. During school visits, the superintendent has the opportunity to speak with administrators, teachers, and students. Research (Carter \& Hord, 1993; Fullan, 2001; Kouzes \& Posner, 2007; Petersen, 1999) indicates that the superintendent’s personal visits to the schools reinforce the importance of the goals of the system. In fact, Pollack, Chrispeels, Watson, Brice, and McCormack’s study (as cited in Carter Glass, \& Hord, 1993), states that the superintendent’s presence in a school “models” instructional leadership in a “symbolic” sense (p. 19). On the other hand, research provided by Crowson and Morris (1990), indicates that even though superintendents frequently visits schools, their operating norm is to leave schools alone. Thus, Crowson and Morris (1990) do state that the superintendent's visit to schools reinforces whether district-wide policies and procedures are being implemented. Additionally, school visits allow the superintendent to observe teacher instruction and student work. Classroom visits may be referred to as WalkThroughs (Lashway, 2002). WalkThroughs give the superintendent the opportunity to visit classrooms and interact with students and teachers. Modeling the way strengthens the role of superintendents as they face the challenges of leading their school systems into the $21^{\text {st }}$ century (Fullan, 2001; Kouzes \& Posner, 2007).

The fourth attribute of the superintendent is organizational adaptation. Creating change in an organization requires imagination (Farmer, 1997; Marx, 2006; Pink, 2006; Zhao, 2007). As the superintendent evaluates and assesses the system, changes are initiated in order to 
improve the system and to allow the system to move forward (Carter, Glass, \& Hord, 1993). A major challenge facing superintendents today is preparing their school systems for the $21^{\text {st }}$ century (Marx, 2006; Pink, 2006; Zhao, 2007). It is during these times that superintendents need to rise to the challenges of the process and search for ways to provide growth and improvement to their school systems (Fullan, 2001; Kouzes \& Posner, 2007). The acceptance of challenges creates opportunities for superintendents to move their school systems forward and not to remain status quo. The superintendent challenges the process and moves into the unknown searching for opportunities to grow and improve (Hermann, 1981; Kouzes \& Posner, 2007).

The superintendent is ultimately responsible for determining change in the school system (Blumberg, 1985; Wallace, 1985). The superintendent must be able to visualize the change and have the capacity to implement the changes. This style of leadership requires the skills associated with wizards and R-Directed Thinking overlapped with the skills associated with warriors and L-Directed Thinking (Herrmann, 1981; Keirsey, 1998; Pink, 2006). The superintendent is responsible for creating the framework for the school system and is also responsible for involving key members of the organization into the process. The involvement of others enables the skills possessed by each member to complement the skills of others, including the superintendent. In addition to being logical about creating the change, the members must develop a caring relationship for each other (Pink, 2006). It is the responsibility of the superintendent to be able to bring about this "whole new mind" way of thinking to advance the school system into the $21^{\text {st }}$ century.

One change that is occurring in schools today to prepare students for the $21^{\text {st }}$ century is the integration of technology skills into the curriculum. A key component in the success of this initiative is the training of teachers. Professional development must be offered and sustained in 
order for teachers to be competent with the implementation. Superintendents must model their support for the teachers to show that they are committed to the vision they articulate (Kouzes \& Posner, 2007; Petersen, 1999). Modeling support for the teachers is an outward, symbolic sign that indicates not only the importance of professional growth but also that the superintendent wants to help them be successful. The professional development offerings assist the school system in moving away from the status quo. This symbolic characteristic of the superintendent provides a strategy to help teachers feel supported by providing them with the training and resources needed to increase student achievement (Johnson \& Uline, 2005). The superintendent, with the support of the school board, is able to allocate funds to support professional growth for administrators and teachers. The professional development sessions enhance the expertise of the teachers so that they may prepare students to perform at a higher level (Petersen, 1999). The superintendent and district leaders have the responsibility of creating policy and procedures that provide teachers with the support needed to improve student performance (Johnson \& Uline, 2005; Sherman \& Grogan, 2003).

However, change for teachers is not always easy. In this case, it is important for the superintendent to develop relationships with the administrators and the professional development council in order to coach the teachers in the right direction. Bishop (as cited by Fullan, 2001) states that leadership in the $21^{\text {st }}$ century must move away from the need to create a product first to the priority of building relationships. Good working relationships between leaders and members of the organization may contribute to how well the job gets done. Fullan (2001) concurs that relationships are important to school systems as they aspire to get results.

Findings from Petersen’s (1999) research identify four attributes that are critical to the superintendent's ability to be instructional leaders. The four attributes include: possess and 
articulate an instructional vision, create an organizational structure that supports the instructional vision and leadership, assess and evaluate personnel and instructional programs, and meet the demands of organizational adaptation. The superintendents in the study (Petersen, 1999) believed establishing a vision for the school system was the most important contributing factor for instructional success. Muller (as cited in Carter, Glass, \& Hord, 1993) found that the competence of superintendents in planning for instruction was the best predictor for district effectiveness. Research (Petersen, 1999; Sherman \& Grogan, 2003; Wallace, 1985) supports that establishing a vision is important for school systems.

The superintendent is able to create enthusiasm by enabling others to see the exciting possibilities of the future. Based on research (Fullan, 2001; Kouzes \& Posner, 2003) the leader’s belief and enthusiasm for the future of the organization is contagious. It is important for the superintendent to create this excitement among the stakeholders because the superintendent cannot lead the school system into the future alone.

Most importantly, as superintendents make changes to prepare their school systems for the $21^{\text {st }}$ century they need the skills associated with wizard, warrior, L-Directed Thinking, and RDirected Thinking characteristics (Pink, 2006). Research (Hermann, 1981; Keirsey, 1998, Pink, 2006) shows that all these skills combined are required for organizations to flourish.

\section{Summary}

The review of the literature in regard to leadership images and directed modes of thinking provides support for a whole new mind as superintendents lead their school systems into the $21^{\text {st }}$ century. The whole new mind represents the characteristics associated with both leadership images and both directed modes of thinking. The leadership images are the wizard and the warrior. The directed modes of thinking are L-Directed Thinking and R-Directed Thinking. The 
L-Directed Thinking aligns itself with the left brain and the R-Directed Thinking aligns itself with the right brain.

The characteristics associated with leadership image of the wizard differ from the characteristics associated with the leadership image of the warrior. The wizard brings creativity, imagination, and meaning to the organization; whereas, the warrior brings mobility, strength, and courage to the organization (Bolman \& Deal, 2006). The characteristics associated with LDirected Thinking differ from the characteristics associated with R-Directed Thinking. Characteristics associated with L-Directed Thinking are sequential, literal, functional, textual, and analytic; whereas, characteristics associated with R-Directed Thinking are simultaneous, metaphorical, aesthetic, contextual, and synthetic (Pink, 2006). The characteristics of LDirected Thinking overlay Bolman and Deal's concept of the warrior. Hence, the characteristics of R-Directed Thinking overlay Bolman and Deal's concept of the wizard.

As leaders prepare their organizations for the $21^{\text {st }}$ century, change will have to occur (Marx, 2006). In order to make changes in organizations, a creative leader is required (Bolman \& Deal, 2006; Herrmann, 1981; Keirsey, 1998; Pink, 2006). The creative leader possesses characteristics that are associated with both L-Directed Thinking and R-Directed Thinking (Pink, 2006). Furthermore, the directed modes of thinking encapsulate the leadership images. It is important for leaders to be able to identify their leadership images and directed modes of thinking as they lead change in their organizations. The leaders will be able to define their strengths and weaknesses which will allow them to move in and out of the image or directed mode of thinking that they do not work in. Also, leaders are able to surround themselves with members of their organizations who possess the skills they lack. 
Superintendents have the responsibility of preparing their school systems for the $21^{\text {st }}$ century. This preparation will require change. In addition to leading change within the school system, superintendents must foster the collaboration and support from the stakeholders in the organization. Through their research, Kouzes and Posner (2007) have identified Five Practices of Exemplary Leadership: model the way, inspire a shared vision, challenge the process, enable others to act, and encourage the heart that strengthens the roles of superintendents as they face the challenges of leading their school systems into the future. Within these five practices are behaviors that support successful leadership. Furthermore, Kouzes and Posner (2007) define leadership as a relationship. The relationship is formed between the leader and members of the organization. In the school system, the superintendent has the opportunity to form relationships with all stakeholders. Fullan (2001) also supports the fact that forming relationships is crucial to the success of school systems especially as they address change. Developing positive relationships with stakeholders is imperative to the success of moving the school system forward. Thus, these relationships are dependent upon the interpersonal skills of leaders which can be associated with leadership images and directed modes of thinking.

Researchers have conducted studies on the relationship between right brain and left brain characteristics and leadership styles and images. This current study will reveal the directed modes of thinking (left brain or right brain) for superintendents in West Virginia today. Superintendents in West Virginia today are preparing to lead their school systems into the $21^{\text {st }}$ century. Research articulates that the creativity is an essential tool for the $21^{\text {st }}$ century leader. 


\section{Chapter 3}

\section{Method}

At the helm of each public school system in West Virginia is the superintendent. Today, the superintendents in West Virginia face the challenge of leading their school systems into the $21^{\text {st }}$ century. This study examines the relationship between the leadership images of West Virginia superintendents and directed modes of thinking. This chapter discusses the methods used in this study. The chapter is structured in eight sections: research design, population, sampling, instrumentations, procedure, data analysis, confidentiality and anonymity and summary.

\section{Research Design}

To determine if there was a statistically significant relationship between the leadership images of West Virginia superintendents and directed modes of thinking, the superintendents' leadership images and directed modes of thinking were initially identified. In this study, the design is appropriate because the two variables are the leadership images and directed modes of thinking of the superintendents. The independent variables leadership image and directed mode of thinking are categorical. According to previous research (Neumann \& Bensimon, 1990; Sherman \& Grogran, 2003; Wallace, 1985), the leadership images of superintendents vary in Bolman and Deal's work. The leadership images consist of the wizard and the warrior, which are discussed in chapters one and two. Each of the images represents a specific outlook with its own beliefs and behaviors. Additionally, previous research (Baron, 1998; Keirsey \& Bates, 1984; Keirsey, 1998; Kouzes \& Posner, 2007; Pink, 2006) shows that there exist different patterns of behavior that affect and determine how leaders function in their organizations. The patterns of behavior are directed modes of thinking which are L-Directed Thinking and R- 
Directed Thinking. In this study, it will be determined if there is a significant statistical relationship between the leadership images of West Virginia superintendents and directed modes of thinking. Furthermore, a correlation design can be utilized in this research to establish the degree of the relationship between leadership images and directed modes of thinking (Hinkle, Wiersma, \& Jurs, 2003).

\section{Population and Sample}

The population for this study consisted of all public school superintendents employed in the county school districts of West Virginia during the 2008-2009 academic school year as identified by the West Virginia Department of Education Directory (see Appendix F). The population, which is the same as the sample size, is 55 . There are 55 public school superintendents in West Virginia (see Appendix F).

\section{Instrumentation}

There were two instruments used in this study to collect leadership image data and directed modes of thinking data. The leadership images of the superintendents were identified by utilization of the Bolman and Deal's Leadership Images: A Leadership Self-Inventory (see Appendix A). The directed modes of thinking of the superintendents were identified by utilization of David Keirsey’s FourTypes Sorter (see Appendix C). The superintendents were also asked to complete an inventory sheet (see Appendix E) regarding demographic information such as their gender, number of years as superintendent, number of years of experience in the school system, and the number of years of experience in education. The demographic information was utilized to provide additional information for cross-tabulated analysis. Additionally, five survey questions appear on the demographic information sheet. The 
superintendents' responses to these questions provide narrative data that enriches the quantitative study.

\section{Leadership Images: A Leadership Self-Inventory Instrument}

The Leadership Images: A Leadership Self-Inventory Instrument, developed by Lee Bolman and Terry Deal in the 2000s is a survey instrument that provides a snapshot of how one leads or at least as one sees himself or herself. The survey contains twelve items. Each item asks the superintendent to rank order four different possibilities. The superintendent uses a fourpoint Likert scale to rate the degree to which the behavior is exhibited. A " 4 " is given to the option that is most like the superintendent. Not the one that the superintendent likes or agrees with most, but the one that comes closest to describing the superintendent. A " 3 ” is given to the one that is next most like the superintendent, and on down to " 1 ” for the option that is least like the superintendent. The superintendents may find it hard to choose because none of the options, or all of the options, may seem like the superintendent. Superintendents should make their selection based on their instincts and move on.

Permission to use the Bolman and Deal Leadership Images: A Leadership Self-Inventory Instrument was granted by Lee Bolman (Appendix B).

The Leadership Images: A Leadership Self-Inventory Instrument, developed by Lee Bolman and Terry Deal in the 2000s is a relatively new measuring instrument; therefore, no information on validity has been provided by Bolman and Deal. The validity and reliability of previous instruments created by Bolman and Deal solidify the validity and reliability of the Leadership Self-Inventory Instrument. The results from this study will contribute to further research using this instrument. 


\section{The Keirsey FourTypes Sorter}

In 1920, a Swiss psychoanalyst Carl Jung invented the term “psychological types” to indicate that people are different in fundamental ways even though they all basically have the same inner instincts (Keirsey \& Bates, 1984). In 1950, Isabel Myers read Jung's book on "psychological types" and with the help of her mother, Katheryn Briggs, created the MyersBriggs Type Indicator (Keirsey \& Bates, 1984). The type theory developed from the works of Jung, and of Myers and Briggs. The Myers-Briggs Type Indicator is a questionnaire about preferences designed to help people determine their personality types. The Myers-Brigg Type Indicator is the most commonly used psychological instrument in the world (Baron, 1998). The instrument comes in fourteen different languages and more than ten million copies have been sold in the early 1990s (Baron, 1998). Also, the Myers-Briggs Type Indicator is a registered trademark of Consulting Psychologists Press, Inc. (Baron, 1998).

The Myers-Briggs list four pairs of opposite preferences (Baron, 1998). The four pairs of opposite preferences are: Extraverting (E) and Introverting (I), Sensing (S) and iNtuiting (N), Thinking (T) and Feeling (F), and Judging ( $\mathrm{J}$ ) and Perceiving (P). Taking one preference from every pair will form the four-letter code that represents each person's type. For example, if a person prefers Introverting, iNtuiting, Feeling, and Perceiving their type is INFP. Collectively there are sixteen different types.

In 1978, the second theory, temperament, was developed by an American clinical psychologist, David Keirsey (Baron, 1998). As he studied the Myers-Briggs descriptions of the sixteen types, he discovered temperament patterns that he had been researching. As a result, he correlated his four temperaments with the sixteen types of the Myers-Briggs system. Today, the type and temperament theory complement each other to provide valuable information. 
According to Keirsey and Bates (1984), “One’s temperament is that which places a signature or thumbprint on each of one's actions, making it recognizably one’s own” (p. 27). The Jung/Myers-Briggs type theory and the Keirsey temperament theory together provide a deep approach to studying personality.

In the Myers-Briggs system, the four temperament themes are called: Sensing Judging (SJ), Sensing Perceiving (SP), iNtuiting Thinking (NT), and iNtuiting Feeling (NF) (Baron, 1998). The Sensing Judging is motivated to be responsible to their social group, whether it be family, the workplace, or the community. The Sensing Perceiving values living for the moment. The iNtuiting Thinking thirsts for knowledge and competency. The iNtuiting Feeling needs to understand themselves and others.

Keirsey uses four Greek gods to name the temperaments: Dionysian, Epimethean, Promethean, and Apollonian (Keirsey \& Bates, 1984). The Dionysian temperament is impulsive and lives for today. The Epimethean temperament exists primarily to be useful to the social units they belong to. The Promethean temperament is able to understand, control, predict, and explain nature. The Apollonian temperament searches for self- actualization.

The Keirsey FourTypes Sorter is a personality instrument that has been used by more than millions of people in several countries since it was first published in 1987. The Keirsey FourTypes Sorter is based on David Keirsey's Temperament theory and is designed to help people learn more about themselves. The Keirsey FourTypes Sorter has been used by companies of all sizes for team building, conflict resolution, leadership development, and job placement. Also, colleges and universities have used the Keirsey FourTypes Sorter for career counseling and graduate research studies. Furthermore, secondary schools have used the Keirsey FourTypes Sorter to improve student performance by determining learning styles. The Keirsey FourTypes 
Sorter consists of sixteen questions and takes ten minutes to complete. Each item asks the superintendent to rank order four different possibilities. A four-point Likert scale is used to rate the response that is most like the superintendent. A " 1 " is given to the option that is most like the superintendent. A "2" is given to the response that is less like the superintendent, and on down to " 4 " for the response that is least like the superintendent.

The procedures for scoring include: the rankings are recorded (1 to 4) for each of the 16 items in the numbered columns on the score sheet, the numbers across each of the four rows are added, and the sum is placed in the boxes on the score sheet. The letter (A, I, G, or R) beside the lowest sum is circled. The letter "A" stands for Artisan, the letter "I" stands for Idealist, the letter "G" stands for Guardian, and the letter "R" stands for Rational.

The four temperaments will be used to determine the directed mode of thinking for the superintendents. Based on the research (Baron, 1998; Bruer, 2008; Keirsey \& Bates, 1998; Keirsey, 1998; Pink, 2006) if a superintendent’s type includes Artisans or Idealists, then the superintendent will be categorized as R-Directed Thinking. On the other hand, if a superintendent’s type includes Guardians or Rationals, the superintendent will be categorized as L-Directed Thinking.

Permission to use the Keirsey Temperament Sorter was granted by purchasing copies of the instrument (Appendix D). Eighty copies of the Keirsey FourTypes Sorter survey were purchased from the publishing company, Prometheus Nemesis Book Company, of the book Please Understand Me II: Temperament, Character, Intelligence written by David Keirsey. A copy of the survey may be found in the book, Please Understand Me II: Temperament, Character, and Intelligence. 
A professional consultation company that specializes in test development, Alpine Media Corporation, published a manual on the assessment of Keirsey’s test (Mental Measurements Yearbook, 2003). The Alpine Media Corporation analyzed data from the Keirsey Temperament Sorters. Over 77,000 people have participated in the statistical assessment. Evidence was found on both the reliability and validity of the Keirsey Temperament Sorters; however, no evidence about race differences or age differences was available.

\section{Procedure}

This research used a self-report survey procedure to collect data pertaining to the leadership images of West Virginia superintendents and directed modes of thinking. The two instruments accompanied by a cover letter (see Appendix G), demographic sheet, and a selfaddressed, stamped envelope were mailed to each of the 55 superintendents. The cover letter defined the purpose of the study, assured confidentiality and anonymity of the superintendents, and requested participation. The superintendents were asked to complete the demographic sheet, respond to the two instruments, and return them to the researcher by August 1, 2008. A followup letter (see Appendix H), another set of surveys, and a demographic sheet were sent three weeks after the initial mailing to superintendents who did not respond. Also, emails were sent and phone calls were made to superintendents who did not respond.

\section{Data Analysis}

The data were generated from the Bolman and Deal's The Leadership Images: A Leadership Self-Inventory and The Keirsey FourTypes Sorter. The statistical methods utilized to analyze the data in order to determine the relationship between the leadership images of superintendents, as measured by the two leadership models described in the research questions in this section, and the directed modes of thinking, as measured by the Keirsey FourTypes Sorter is 
described in the research questions in this section. The Statistical Package for the Social Sciences (SPSS) was used for the required statistical computations. An alpha level of .05 was the level of significance for this study.

Question 1. What are the leadership images (as measured by Bolman and Deal's images of leadership) of West Virginia superintendents?

The Bolman and Deal's The Leadership Images: A Leadership Self-Inventory was utilized to collect data regarding question one. The frequencies and percentage of the superintendents who utilized patterns of either a wizard or warrior were identified and reported. If the score for the wizard and the warrior are a tie, then the superintendents' responses to item number twelve on the instrument was used to determine if the superintendents' were wizards or warriors. Item number twelve on the survey instrument asks the superintendents if they are an analyst, a caregiver, a warrior or a wizard. If the wizard receives the higher mark, then the superintendents will be categorized as wizards. If the warrior receives the higher mark, then the superintendents will be categorized as warriors.

Question 2. What are the temperaments, L-Directed Thinking or R-Directed Thinking, (as measured by The Keirsey FourTypes Sorter) of West Virginia superintendents?

The Keirsey FourTypes Sorter was utilized to collect data regarding question two. The frequencies and percentages of the superintendents who utilized patterns of either right brain leaders or left brain leaders were identified and reported.

Question 3. Is there a statistically significant (>.05) relationship between leadership images and directed modes of thinking? 
To examine Research Question 3, a Chi-Square Test of Independence was conducted on leadership images (wizard and warrior) and directed modes of thinking (L-Directed Thinking and R-Directed Thinking).

Question 4. Are there statistically significant (>.05) differences in leadership images of West Virginia superintendents by gender (male or female), size of the student population in the school system $($ small $=$ less than 3000/medium $=3000-6000 /$ large $=$ more than 6000$)$, the student free and reduced status of the school system (low $=$ less than $50 \% /$ medium $=50 \%-60 \%$ / high $=$ more than $60 \%$ ), the number of years as the superintendent $($ emergent $=0-5$ years $/$ mid-career $=$ 6-10 years/established = more than 10 years), the superintendent's number of years in the school system (emergent $=0-5$ years $/$ mid-career $=6-10$ years/established $=$ more than 10 years $)$ and the superintendent's number of years of experience in education (emergent $=0-5$ years $/$ mid-career $=$ 6-10 years/established = more than 10 years)?

To examine Research Question 4, a series of six chi-squares were conducted on leadership styles (wizard and warrior) by demographic variables (Gender, School Size, Student Free and Reduced Status, Years of Experience as Superintendent, Years of Experience in School System, and Years of Experience in Education).

Question 5. Are there statistically significant (>.05)differences in the directed modes of thinking of West Virginia superintendents by gender (male or female), size of the student population in the school system (small = less than 3000/medium $=3000-6000 /$ large $=$ more than 6000 ), the student free and reduced status of the school system (low $=$ less than $50 \% /$ medium $=$ $50 \%-60 \%$ / high $=$ more than $60 \%$ ), the number of years as the superintendent (emergent $=0-5$ years $/$ mid-career $=6-10$ years/established $=$ more than 10 years $)$, the superintendent's number of years in the school system $($ emergent $=0-5$ years $/$ mid-career $=6-10$ years $/$ established $=$ more 
than 10 years) and the superintendent's number of years of experience in education (emergent = 0-5 years/mid-career $=6-10$ years/established $=$ more than 10 years $) ?$

To examine Research Question 5, a series of six chi-squares were conducted on directed modes of thinking (right brain and left brain) by demographic variables (Gender, School Size, Student Free and Reduced Status, Years of Experience as Superintendent, Years of Experience in School System, and Years of Experience in Education).

\section{Confidentiality and Anonymity}

This study was dependent upon responses from human subjects and requires their voluntary participation. Their anonymity and confidentiality was protected consistent with the Institutional Review Board (IRB) standards and policies. In the cover letter, the subjects were provided with information such as the purpose or the research, a comment that participation is voluntary, and the assurance of confidentiality and anonymity. Participant codes were assigned to protect the identity of each of the respondents. Cover letters are included in appendices and are labeled accordingly: cover letter to superintendents (see Appendix G) and cover letter to superintendents for a second mailing (see Appendix H). Survey responses were coded with numbers for subsequent use and all identities were kept confidential. Approval by the West Virginia University Institution Review Board for the Protection of Human Subjects is documented in Appendix I.

\section{Summary}

In this chapter, the method used to examine the relationship between the leadership images of West Virginia superintendents and directed modes of thinking was designed. The West Virginia public school superintendents were surveyed with Bolman and Deal's The Leadership Images: A Leadership Self-Inventory and The Keirsey FourTypes Sorter. Also, the 
superintendents were asked six qualitative questions that are related to their work as superintendents. Additionally, the superintendents were asked to complete an inventory on demographics regarding their gender, size of their school system, the socio-economic status of their school system, the number of years as the superintendent, the number of years in the school system, and the number of years of experience in education. The surveys were mailed to the superintendents and the superintendents’ responded by using the enclosed self-addressed, stamped-envelope. The Statistical Package for the Social Sciences (SPSS) was used for statistical computations to analyze the data. An alpha level of .05 was the criterion level of significance for this study. The results of the data analysis are presented in Chapter 4. 


\section{Chapter 4}

Presentation and Analysis of Data

The purpose of this study was to determine the relationship between the leadership images of West Virginia superintendents and directed modes of thinking. The study examines whether there is a statistically significant relationship between the leadership images of West Virginia superintendents and directed modes of thinking.

This chapter provides a description and analysis of the data collected by Bolman and Deal's (2006) The Leadership Images: A Leadership Self-Inventory and the Keirsey FourTypes Sorter (1998). The chapter is divided into four sections: (a) descriptive data, (b) statistical analysis of data, (c) major findings, and (d) summary of the chapter.

\section{Descriptive Data}

The population for this study consisted of all public school superintendents $(\mathrm{N}=55)$ employed in West Virginia for the 2008-2009 academic school year. Overall, 46 or 84\% of the superintendents responded. Two returns were rejected because both instruments were not completed.

Demographic data that were collected from the respondents included the following items: (a) gender, (b) total years in education, (c) total years at current school system, (d) number of years as superintendent, (e) size of student population, and (f) student free and reduced status. Data indicate that of the 44 respondents, 26 (59\%) were male and 18 (41\%) were female (Table 1). The total population of 55 superintendents consisted of 36 (65\%) males and 19 (35\%) females. 
Table1

Frequency Distribution of Respondents by Gender

\begin{tabular}{lll}
\hline Gender & Frequency & Percent \\
\hline Male & 26 & 59 \\
Female & 18 & 41 \\
\hline Total & 44 & 100 \\
\hline
\end{tabular}

Note. There are 36 male superintendents and 19 female superintendents in West Virginia.

Data reveal that none of the superintendents (0\%) had less than five total years in education, none (0\%) had between 5 and 10, and all 44 superintendents (100\%) had more than 10 years in education (Table 2).

Table 2

Frequency Distribution of Respondents by Total Years in Education

\begin{tabular}{lll}
\hline $\begin{array}{l}\text { Total Years } \\
\text { in Education }\end{array}$ & Frequency & Percent \\
\hline Less than 5 & 0 & 0 \\
$5-10$ & 0 & 0 \\
More than 10 & 44 & 100 \\
\hline Total & 44 & 100 \\
\hline
\end{tabular}


Data reveal that nine (21\%) superintendents had less than five years in the current school system, eight (18\%) had between 5 and 10, and 27 (61\%) had more than 10 years in the current school system (Table 3).

Table 3

Frequency Distribution of Respondents by Total Years in Current School System

\begin{tabular}{lll}
\hline $\begin{array}{l}\text { Total Years } \\
\text { in Current } \\
\text { School System }\end{array}$ & Frequency & Percent \\
\hline Less than 5 & 9 & 21 \\
$5-10$ & 8 & 18 \\
More than 10 & 27 & 61 \\
\hline Total & 44 & 100 \\
\hline
\end{tabular}

Data reveal that 25 (57\%) superintendents had spent five years or less in the position, 12 (27\%) had between 5 and 10, and seven (16\%) had served more than 10 years as the superintendent (Table 4). 
Table 4

Frequency Distribution of Respondents by Total Years as Superintendent

\begin{tabular}{lll}
\hline $\begin{array}{l}\text { Total Years } \\
\text { as Superintendent }\end{array}$ & Frequency & Percent \\
\hline Less than 5 & 25 & 57 \\
$5-10$ & 12 & 27 \\
More than 10 & 7 & 16 \\
\hline Total & 44 & 100 \\
\hline
\end{tabular}

Data reveal that 19 (43\%) superintendents have school districts with a student population of less than 3,000 students. Fourteen superintendents (32\%) work in school districts with a student population between 3,000 and 6,000 students. Eleven superintendents (25\%) work in school districts with a student population greater than 6,000 students (Table 5). 
Table 5

Frequency Distribution of Respondents by Size of Student Population

\begin{tabular}{lcc}
\hline $\begin{array}{l}\text { Size of Student } \\
\text { Population }\end{array}$ & Frequency & Percent \\
\hline Less than 3,000 & 19 & 43 \\
$3,000-6,000$ & 14 & 32 \\
More than 6,000 & 11 & 25 \\
\hline Total & 44 & 100 \\
\hline
\end{tabular}

Note. Size of student population in all West Virginia counties is as follows: less than 3,000 23 ; 3,000 to $6,000-18$; over $6,000-14$.

Data reveal that 17 (39\%) superintendents have school districts with less than $50 \%$ of their students qualifying for free and reduced status. Eighteen superintendents (41\%) work in school districts with between $50 \%$ and $60 \%$ of their students qualifying for free and reduced status. Nine superintendents (20\%) work in school districts with more than $60 \%$ of their students qualifying for free and reduced status (Table 6). 
Table 6

Frequency Distribution of Respondents by Student Free and Reduced Status

Student Free and

Frequency

Percent

Reduced Status

17

39

$50 \%-60 \%$

18

41

More than 60\%

9

20

Total

44

100

Note. Student Free and Reduced Status in all West Virginia counties is as follows: less than $50 \%-20 ; 50 \%$ to $60 \%$ - 23; over $60 \%-12$.

\section{Statistical Analysis of Data}

The instrument used in this study to collect data with respect to wizards and warriors was Bolman and Deal's (2006) Leadership Images: A Leadership Self-Inventory; whereas, the instrument used to collect data with respect to directed modes of thinking was the Keirsey FourTypes Sorter (1998). Additionally, the superintendents were asked to respond to five survey questions.

Bolman and Deal’s (2006) Leadership Images: A Leadership Self-Inventory contains 12 items. Each item asked the superintendent to rank order four different possibilities. The superintendent used a four-point Likert scale to rate the degree to which the behavior is exhibited. A " 4 " is given to the option that is most like the superintendent, not the one that the superintendent likes or agrees with most, but the one that comes closest to describing the 
superintendent. A " 3 " is given to the one that is next like the superintendent, and so on to " 1 " for the option that is least like the superintendent. The frequencies and percentages of the superintendents who utilized patterns of either a wizard or warrior were identified and reported. If the score for the wizard and the warrior were a tie, then the superintendents' responses to item number 12 on the instrument were used to determine if the superintendents were wizards or warriors. Item number 12 on the survey instrument asked the superintendents if they are an analyst, a caregiver, a warrior, or a wizard. If the wizard received the higher mark, then the superintendents were categorized as wizards. If the warrior received the higher mark, then the superintendents were categorized as warriors.

The second survey instrument, Keirsey FourTypes Sorter (1998), is a 16 item questionnaire. Subjects responded to each item by using a four-point Likert scale. A “1” was given to the option that is most like the superintendent. A " 2 " is given to the response that was less like the superintendent, and on up to “4” for the response that was least like the superintendent. The procedures for scoring included: recording the rankings (1 to 4 ) for each of the 16 items in the numbered columns on the score sheet, the numbers across each of the four rows were added, and the sum was placed in the boxes on the score sheet. The letter (A, I, G, or R) beside the lowest sum was circled. The letter "A" stands for Artisan, the letter "I" stands for Idealist, the letter "G” stands for Guardian, and the letter "R” stands for Rational. The four temperaments were used to determine the directed mode of thinking (L-Directed Thinking or RDirected Thinking) for the superintendents. If the superintendent's type included Artisans or Idealists, then the superintendent was categorized as R-Directed Thinking. On the other hand, if a superintendent's type included Guardians or Rationals, the superintendent was categorized as L-Directed Thinking. The frequencies and percentages of the superintendents who utilized 
patterns of either L-Directed Thinking (left brain) or R-Directed (right brain) were identified and reported.

\section{Major Findings}

The presentation and analysis of findings is organized into five parts, each part relating to one of the research questions.

Research Question 1. What are the leadership images (as measured by Bolman and Deal's images of leadership) of West Virginia superintendents?

Data reveal that 25 of the superintendents (57\%) are wizards, and 19 of the superintendents (43\%) are warriors (Table 7).

Table 7

Frequency Distribution of Respondents by Leadership Image

\begin{tabular}{lcc}
\hline Leadership Image & Frequency & Percent \\
\hline Wizard & 25 & 57 \\
Warrior & 19 & 43 \\
\hline Total & 44 & 100 \\
\hline
\end{tabular}

Research Question 2. What are the temperaments, L-Directed Thinking or R-Directed Thinking, (as measured by the Keirsey FourTypes Sorter) of West Virginia superintendents?

Data reveal that 23 of the superintendents (52\%) are L-Directed Thinking, and 21 of the superintendents (48\%) are R-Directed Thinking (Table 8). 
Table 8

Frequency Distribution of Respondents by Directed Mode of Thinking

\begin{tabular}{lcc}
\hline $\begin{array}{l}\text { Directed Mode } \\
\text { of Thinking }\end{array}$ & Frequency & Percent \\
\hline L-Directed & 23 & 52 \\
R-Directed & 21 & 48 \\
\hline Total & 44 & 100 \\
\hline
\end{tabular}

Research Question 3. Is there a statistically significant (>.05) relationship between leadership images and directed modes of thinking?

A Chi-Square Test of Independence was conducted on leadership images (wizard or warrior) and directed modes of thinking (L-Directed Thinking or R-Directed Thinking). Data in Table 9 confirm that there is no statistically significant (>.05) relationship between leadership images and directed modes of thinking, $X^{2}(1, N=44)=.002, p>.05$. 
Table 9

Leadership Images and Directed Modes of Thinking

\begin{tabular}{llll}
\hline & Wizard & Warrior & Total \\
\hline L-Directed & 13 & 10 & 23 \\
R-Directed & 12 & 9 & 21 \\
\hline Total & 25 & 19 & 44 \\
\hline
\end{tabular}

Research Question 4. Are there statistically significant (> .05) differences in leadership images (wizard or warrior) of West Virginia superintendents by gender (male or female), size of the student population in the school system ( small $=$ less than 3,000/medium $=3,000-6,000 /$ large $=$ more than 6,000 ), the student free and reduced status of the school system (low = less than $50 \% /$ medium $=50 \%-60 \% /$ high $=$ more than $60 \%$, the number of years as the superintendent (emergent $=0-5$ years $/$ mid-career $=6-10$ years/established $=$ more than 10 years $)$, the superintendent's number of years in the school system (emergent $=0-5$ years/mid-career $=6-10$ years/established = more than 10 years) and the superintendent's number of years of experience in education $($ emergent $=0-5$ years $/$ mid-career $=6-10$ years/established $=$ more than 10 years $)$ ?

To examine Research Question 4, a series of six Chi-Square Tests of Independence were conducted on leadership images (wizard or warrior) by demographic variables (Gender, School Size, Student Free and Reduced Status, Years of Experience as Superintendent, Years of Experience in School System, and Years of Experience in Education). 
A Chi-Square Test of Independence was conducted on leadership images (wizard or warrior) and gender (male or female). Data in Table 10 confirm that there is no statistically significant (>.05) relationship between leadership images and gender, $X^{2}(1, N=44)=1.204$, $p>.05$.

Table 10

Leadership Images and Gender

\begin{tabular}{llll}
\hline & Wizard & Warrior & Total \\
\hline Male & 13 & 13 & 26 \\
Female & 12 & 6 & 18 \\
\hline Total & 25 & 19 & 44 \\
\hline
\end{tabular}

A Chi-Square Test of Independence was conducted on leadership images (wizard or warrior) and the size of the student population in the school system (small = less than 3,000 /medium $=3,000-6,000 /$ large $=$ more than 6,000 ). Data in Table 11 confirm that there is no statistically significant (>.05) relationship between leadership images and the size of student population in the school system, $X^{2}(2, N=44)=1.632, p>.05$. 
Table 11

Leadership Images and Size of Student Population

\begin{tabular}{llll}
\hline & Wizard & Warrior & Total \\
\hline Less than 3,000 & 12 & 7 & 19 \\
$3,000-6,000$ & 6 & 8 & 14 \\
More than 6,000 & 7 & 4 & 11 \\
\hline Total & 25 & 19 & 44 \\
\hline
\end{tabular}

A Chi-Square Test of Independence was conducted on leadership images (wizard or warrior) and the student free and reduced status of the school system (low = less than $50 \% /$ medium $=50 \%-60 \% /$ high $=$ more than 60\%). Data in Table 12 confirm that there is no statistically significant $(>.05)$ relationship between leadership images and the student free and reduced status of the school system, $X^{2}(2, N=44)=.725, p>.05$. 
Table 12

Leadership Images and Student Free and Reduced Status

\begin{tabular}{llll}
\hline & Wizard & Warrior & Total \\
\hline Less than $50 \%$ & 10 & 7 & 17 \\
$50 \%-60 \%$ & 11 & 7 & 18 \\
More than $60 \%$ & 4 & 5 & 9 \\
\hline Total & 25 & 19 & 44 \\
\hline
\end{tabular}

A Chi-Square Test of Independence was conducted on leadership images (wizard or warrior) and the number of years as the superintendent (emergent $=0$-5 years $/$ mid-career $=6-10$ years/established $=$ more than 10 years). Data in Table 13 confirm that there is no statistically significant $(>.05)$ relationship between leadership images and the number of years as the superintendent, $X^{2}(2, N=44)=1.037, p>.05$. 
Table 13

Leadership Images and Number of Years as Superintendent

\begin{tabular}{llll}
\hline & Wizard & Warrior & Total \\
\hline $0-5$ Years & 14 & 11 & 25 \\
$6-10$ Years & 8 & 4 & 12 \\
More than 10 Years & 3 & 4 & 7 \\
\hline Total & 25 & 19 & 44 \\
\hline
\end{tabular}

However, since more than $20 \%$ of the cells have expected frequencies less than five, it is recommended to combine adjacent rows or columns to conduct the Chi-Square Test of Independence (Hinkle, Wiersma, \& Jurs, 2003). Therefore, row two and row three have been combined in Table 14. Data in Table 14 confirm that there is no statistically significant $(>.05)$ relationship between leadership images and the number of years as the superintendent, $X^{2}(1, N=$ 44) $=.002, p>.05$. 
Table 14

Leadership Images and Number of Years as Superintendent

\begin{tabular}{llll}
\hline & Wizard & Warrior & Total \\
\hline $0-5$ Years & 14 & 11 & 25 \\
More than 5 Years & 11 & 8 & 19 \\
\hline Total & 25 & 19 & 44 \\
\hline
\end{tabular}

A Chi-Square Test of Independence was conducted on leadership images (wizard or warrior) and the superintendent's number of years in the school system (emergent $=0-5$ years/mid-career $=6-10$ years/established $=$ more than 10 years $)$. Data in Table 15 confirm that there is no statistically significant (>.05) relationship between leadership images and the superintendent's number of years in the school system, $X^{2}(2, N=44)=2.544, p>.05$. 
Table 15

Leadership Images and Number of Years in School System

\begin{tabular}{llll}
\hline & Wizard & Warrior & Total \\
\hline $0-5$ Years & 3 & 6 & 9 \\
$6-10$ Years & 5 & 3 & 8 \\
More than 10 Years & 17 & 10 & 27 \\
\hline Total & 25 & 19 & 44 \\
\hline
\end{tabular}

However, since more than $20 \%$ of the cells have expected frequencies less than five, it is recommended to combine adjacent rows or columns to conduct the Chi-Square Test of Independence (Hinkle, Wiersma, \& Jurs, 2003). Therefore, row one and row two have been combined in Table 16. Data in Table 16 confirm that there is no statistically significant $(>.05)$ relationship between leadership images and the superintendent's number of years in the school system, $X^{2}(1, N=44)=.015, p>.05$. 
Table 16

Leadership Images and Number of Years in School System

\begin{tabular}{llll}
\hline & Wizard & Warrior & Total \\
\hline $0-10$ Years & 8 & 9 & 17 \\
More than 10 Years & 17 & 10 & 27 \\
\hline Total & 25 & 19 & 44 \\
\hline
\end{tabular}

A Chi-Square Test of Independence was not able to be conducted on leadership images (wizard or warrior) and the superintendent's number of years of experience in education (emergent $=0-5$ years $/$ mid-career $=6-10$ years $/$ established $=$ more than 10 years) because more than one of the cells has no frequencies. If more than one of the cells has no frequencies, even if adjacent rows or columns are combined, a Chi-Square Test of Independence cannot be conducted (Hinkle, Wiersma, \& Jurs, 2003). The data in Table 17 confirm that a Chi-Square Test of Independence cannot be conducted; therefore, a statement addressing the relationship between leadership images and the superintendent's number of years of experience in education cannot be made. The incidence of not being able to conduct a Chi-Square Test of Independence on leadership images and the superintendent's number of years of experience in education is a limitation to this study. 
Table 17

Leadership Images and Number of Years of Experience

\begin{tabular}{llll}
\hline & Wizard & Warrior & Total \\
\hline $0-5$ Years & 0 & 0 & 0 \\
$6-10$ Years & 0 & 0 & 0 \\
More than 10 Years & 25 & 19 & 44 \\
\hline Total & 25 & 19 & 44 \\
\hline
\end{tabular}

Research Question 5. Are there statistically significant (> .05) differences in the directed modes of thinking (L-Directed Thinking or R-Directed Thinking) of West Virginia superintendents by gender (male or female), size of the student population in the school system (small $=$ less than 3,000/medium $=3,000-6,000 /$ large $=$ more than 6,000), the student free and reduced status of the school system (low $=$ less than $50 \% /$ medium $=50 \%-60 \% /$ high $=$ more than $60 \%)$, the number of years as the superintendent $($ emergent $=0-5$ years/mid-career $=6-10$ years/established $=$ more than 10 years), the superintendent's number of years in the school system $($ emergent $=0-5$ years $/$ mid-career $=6-10$ years/established $=$ more than 10 years $)$ and the superintendent's number of years of experience in education $($ emergent $=0-5$ years $/$ mid-career $=$ 6-10 years/established $=$ more than 10 years) $?$

To examine Research Question 5, a series of six Chi-Square Tests of Independence were conducted on directed modes of thinking (L-Directed Thinking or R-Directed Thinking) by 
demographic variables (Gender, School Size, Student Free and Reduced Status, Years of Experience as Superintendent, Years of Experience in School System, and Years of Experience in Education).

A Chi-Square Test of Independence was conducted on directed modes of thinking (LDirected Thinking or R-Directed Thinking) and gender (male or female). Data in Table 18 confirm that there is a statistically significant (>.05) relationship between directed modes of thinking and gender, $X^{2}(1, N=44)=4.380, p<.05$.

Table 18

Directed Modes of Thinking and Gender

\begin{tabular}{llll}
\hline & L-Directed & R-Directed & Total \\
\hline Male & 17 & 9 & 26 \\
Female & 6 & 12 & 18 \\
\hline Total & 23 & 21 & 44 \\
\hline
\end{tabular}

A Chi-Square Test of Independence was conducted on directed modes of thinking (LDirected or R-Directed) and the size of the student population in the school system (small = less than 3,000/medium $=3,000-6,000 /$ large $=$ more than 6,000). Data in Table 19 confirm that there is no statistically significant (>.05) relationship between directed modes of thinking and the size of student population in the school system, $X^{2}(2, N=44)=.339, p>.05$. 
Table 19

Directed Modes of Thinking and Size of Student Population

\begin{tabular}{llll}
\hline & L-Directed & R-Directed & Total \\
\hline Less than 3,000 & 9 & 10 & 19 \\
$3,000-6,000$ & 8 & 6 & 14 \\
More than 6,000 & 6 & 5 & 11 \\
\hline Total & 23 & 21 & 44 \\
\hline
\end{tabular}

A Chi-Square Test of Independence could not be conducted on directed modes of thinking (L-Directed Thinking or R-Directed Thinking) and the student free and reduced status of the school system (low $=$ less than $50 \%$ /medium $=50 \%-60 \% /$ high $=$ more than $60 \%$ ) because more than $20 \%$ of the cells have expected frequencies less than five. If more than $20 \%$ of the cells have expected frequencies less than five it is recommended to combine adjacent rows or columns; however, the rows containing cells having expected frequencies less than five are not adjacent (Hinkle, Wiersma, \& Jurs, 2003). Thus, a statement addressing the relationship between directed modes of thinking and the student free and reduced status of the school system cannot be made.

Data in Table 20 confirm that a Chi-Square Test of Independence cannot be conducted. The occurrence of not being able to conduct a Chi-Square Test of Independence on directed modes of thinking and student free and reduced status is a limitation to this study. 
Table 20

Directed Modes of Thinking and Student Free and Reduced Status

\begin{tabular}{llll}
\hline & L-Directed & R-Directed & Total \\
\hline Less than $50 \%$ & 14 & 3 & 17 \\
$50 \%-60 \%$ & 6 & 12 & 18 \\
More than $60 \%$ & 3 & 6 & 9 \\
\hline Total & 23 & 21 & 44 \\
\hline
\end{tabular}

A Chi-Square Test of Independence was conducted on directed modes of thinking (LDirected Thinking or R-Directed Thinking) and the number of years as the superintendent (emergent $=0-5$ years $/$ mid-career $=6-10$ years $/$ established $=$ more than 10 years). Data in Table 21 confirm that there is no statistically significant (>.05) relationship between directed modes of thinking and the number of years as the superintendent, $X^{2}(2, N=44)=2.894, p>.05$. 
Table 21

Directed Modes of Thinking and Number of Years as Superintendent

\begin{tabular}{llll}
\hline & L-Directed & R-Directed & Total \\
\hline $0-5$ Years & 14 & 11 & 25 \\
$6-10$ Years & 4 & 8 & 12 \\
More than 10 Years & 5 & 2 & 7 \\
\hline Total & 23 & 21 & 44 \\
\hline
\end{tabular}

However, since more than $20 \%$ of the cells have expected frequencies less than five, it is recommended to combine adjacent rows or columns to conduct the Chi-Square Test of Independence (Hinkle, Wiersma, \& Jurs, 2003). Therefore, row two and row three have been combined in Table 22. Data in Table 22 confirm that there is no statistically significant (>.05) relationship between directed modes of thinking and the number of years as the superintendent, $X^{2}(1, N=44)=.322, p>.05$. 
Table 22

Directed Modes of Thinking and Number of Years as Superintendent

\begin{tabular}{llll}
\hline & L-Directed & R-Directed & Total \\
\hline $0-5$ Years & 14 & 11 & 25 \\
More than 5 Years & 9 & 10 & 19 \\
\hline Total & 23 & 21 & 44 \\
\hline
\end{tabular}

A Chi-Square Test of Independence was conducted on directed modes of thinking (LDirected Thinking or R-Directed Thinking) and the superintendent's number of years in the school system (emergent $=0-5$ years $/$ mid-career $=6-10$ years/established $=$ more than 10 years $)$. Data in Table 23 confirm that there is no statistically significant (>.05) relationship between directed modes of thinking and the superintendent's number of years in the school system, $X^{2}(2$, $N=44)=1.746, p>.05$. 
Table 23

Directed Modes of Thinking and Number of Years in School System

\begin{tabular}{llll}
\hline & L-Directed & R-Directed & Total \\
\hline $0-5$ Years & 3 & 6 & 9 \\
$6-10$ Years & 5 & 3 & 8 \\
More than 10 Years & 15 & 12 & 27 \\
\hline Total & 23 & 21 & 44 \\
\hline
\end{tabular}

However, since more than $20 \%$ of the cells have expected frequencies less than five, it is recommended to combine adjacent rows or columns to conduct the Chi-Square Test of Independence (Hinkle, Wiersma, \& Jurs, 2003). Therefore, row one and row two have been combined in Table 24. Data in Table 24 confirm that there is no statistically significant $(>.05)$ relationship between directed modes of thinking and the superintendent's number of years in the school system, $X^{2}(1, N=44)=.302, p>.05$. 
Table 24

Directed Modes of Thinking and Number of Years in School System

\begin{tabular}{llll}
\hline & L-Directed & R-Directed & Total \\
\hline $0-10$ Years & 8 & 9 & 17 \\
More than 10 Years & 15 & 12 & 27 \\
\hline Total & 23 & 21 & 44 \\
\hline
\end{tabular}

A Chi-Square Test of Independence was not able to be conducted on directed modes of thinking (L-Directed Thinking or R-Directed Thinking) and the superintendent's number of years of experience in education $($ emergent $=0-5$ years $/$ mid-career $=6-10$ years $/$ established $=$ more than 10 years) because more than one of the cells has no frequencies. If more than one of the cells has no frequencies, even if adjacent rows or columns are combined, a Chi-Square Test of Independence cannot be conducted (Hinkle, Wiersma, \& Jurs, 2003). The data in Table 25 confirm that a Chi-Square Test of Independence cannot be conducted; therefore, a statement addressing the relationship between directed modes of thinking and the superintendent's number of years of experience in education cannot be made. The incidence of not being able to conduct a Chi-Square Test of Independence on directed modes of thinking and the superintendent's number of years of experience in education is a limitation to this study. 
Table 25

Directed Modes of Thinking and Number of Years of Experience

\begin{tabular}{llll}
\hline & L-Directed & R-Directed & Total \\
\hline $0-5$ Years & 0 & 0 & 0 \\
$6-10$ Years & 0 & 0 & 0 \\
More than 10 Years & 23 & 21 & 44 \\
\hline Total & 23 & 21 & 44 \\
\hline
\end{tabular}

Qualitative Survey Questions

Additionally, the following five survey questions, located on the demographic information sheet, were asked of the superintendents:

1. As the superintendent of your school system, what is your vision for the $21^{\text {st }}$ century learner?

2. How will you communicate your vision to the stakeholders in your school system?

3. What work motivates you to create an organizational structure that supports the instructional vision of the school system?

4. How do you assess and evaluate personnel and instructional programs in your school system?

5. What are the common characteristics of the work you do to meet the demands of organizational adaptation? 
The responses garnered from the five questions asked of the superintendents were divided into four columns. The first column listed the responses from superintendents who were identified as wizards and L-Directed Thinking, the second column listed the responses from the superintendents who were identified as wizards and R-Directed Thinking, the third column listed the responses from the superintendents who were identified as warriors and L-Directed Thinking, and the fourth column listed the responses from the superintendents who were identified as warriors and R-Directed Thinking. Thus, common themes emerged from the responses to each question regardless of wizard, warrior, L-Directed Thinking, or R-Directed Thinking characteristics.

In response to question one, the superintendents agree that the vision for the $21^{\text {st }}$ century learner is a productive citizen who is able to adapt to a changing world and work collaboratively with others. The common vehicles used by the superintendents to communicate the vision of their school systems to stakeholders are shared leadership and modeling the desired behavior. Additionally, a multi-pronged communication approach, which includes news releases, presentations, blogs, emails, and other $21^{\text {st }}$ century tools, is used by the superintendents to communicate the vision of their school systems. The common response that emerged from question three was unanimous. It is the success of students that truly motivates the superintendents to create an organizational structure that supports the instructional vision of their school systems. Student success is defined by performance on standardized tests, ability to function in society, and overcoming barriers to learning. The superintendents assess and evaluate personnel and instructional programs by analyzing data such as WESTEST scores, graduation rate, and dropout rates. Personnel and instructional programs are also observed by visiting schools and classrooms. Informal conversations with staff also provide feedback to the 
superintendents on instructional programs. In response to question five, good communication and organizational skills are important to the superintendents as they strive to meet the demands of organizational adaptation. Skills include fairness, willingness to listen, creativity, and enthusiasm.

The profile of the typical superintendent participating in the study is reflected in Table 26. The typical superintendent is male, accrued more than ten years in education, served in the current school district more than five years, and held the post of superintendent for less than ten years. Data also reveal that the typical superintendent served in a school district having less than 6,000 students with a student free and reduced status less than $60 \%$.

Table 26

Profile of the Typical Superintendent

Variable Study Finding

Gender

Male (59\%)

Total Years in Education

More than 10 (100\%)

Total Years in Current School System

More than 10 (61\%)

Total Years as Superintendent

Less than 5 (57\%)

Size of Student Population

6,000 or Less (75\%)

Student Free and Reduced Status

$60 \%$ or Less (80\%) 


\section{Summary of the Chapter}

Forty-four West Virginia public school superintendents participated in this study to examine the relationship between leadership images and directed modes of thinking. This investigation was carried out through survey research procedures utilizing two instruments to determine the superintendents' leadership images and their directed modes of thinking.

Data collected in the study related to two specific types of leadership images (wizard or warrior) and two types of directed modes of thinking (L-Directed Thinking or R-Directed Thinking). Data were analyzed at the .05 alpha level of significance using the Statistical Package for the Social Sciences (SPSS). A frequency distribution of leadership image and directed mode of thinking was conducted to answer Research Question 1 and Research Question 2. Chi-Square Tests of Independence were computed to answer Research Question 3, Research Question 4, and Research Question 5.

The data collected to answer the Research Question 1 revealed that 25 superintendents (57\%) are wizards and 19 superintendents (43\%) are warriors. The data collected to answer Research Question 2 revealed that 23 of the superintendents (52\%) are L-Directed Thinking and 21 of the superintendents (48\%) are R-Directed Thinking. The data collected to answer Research Question 3 found that there is no statistically significant relationship between leadership images and directed modes of thinking. The data collected to answer Research Question 4 found that there is no statistically significant relationship between leadership images and the following items: (a) gender, (b) size of student population, (c) student free and reduced status, (d) number of years as superintendent, and (e) number of years in the system. Thus, a Chi-Square Test of Independence could not be conducted on leadership images and total years in education because all respondents had more than 10 years of experience. The lack of being able 
to conduct the Chi-Square Test of Independence is a limitation to this study. The data collected to answer Research Question 5 found that there is no statistically significant relationship between directed modes of thinking and the following items: (a) size of student population, (b) number of years as superintendent, and (c) number of years in the system. Thus, a Chi-Square Test of Independence conducted on directed modes of thinking and gender indicated that there is a significant relationship between directed modes of thinking and gender. Furthermore, a ChiSquare Test of Independence could not be conducted on directed modes of thinking and student free and reduced status. The lack of being able to conduct the Chi-Square Test of Independence is a limitation to this study. Additionally, a Chi-Square Test of Independence could not be conducted on directed modes of thinking and total years in education because all respondents had more than 10 years of experience. The lack of being able to conduct the Chi-Square Test of Independence is a limitation to this study. 


\section{Chapter 5}

Conclusions, Further Analyses, Implications, and Recommendations

This chapter provides conclusions, further analyses, implications, and recommendations based on the major findings of this study. The conclusions and further analyses reached in this study are practical and functional, and they identify critical, constructive traits that superintendents must acquire as they lead their school systems to meet student success in a changing global environment. A school system may attain strategic advantage by seeking and promoting these leadership traits in its superintendent. In light of these important implications, school leaders may study and apply this research to the selection process for superintendents as well as the professional development of superintendents. Recommendations include further research to determine the relationship between leadership images and directed modes of thinking.

\section{Conclusions and Further Analyses}

This study examines the relationship between leadership images, as defined by The Leadership Images: A Leadership Self-Inventory Instrument (Bolman \& Deal, 2006), and directed modes of thinking, as measured by Keirsey’s FourTypes Sorter (Keirsey, 1988). Study of the leadership images and directed modes of thinking of West Virginia superintendents identifies the type of administrative leadership currently in place throughout public education in West Virginia. The leadership images and directed modes of thinking of West Virginia public school superintendents provide data to support several conclusions and further analyses.

\section{Leadership Images of West Virginia Superintendents}

Research Question 1. What are the leadership images (as measured by Bolman and Deal's images of leadership) of West Virginia Superintendents? 
More wizards can be identified among West Virginia superintendents who participated in this study than warriors. The frequency distribution of leadership images of West Virginia superintendents reveals that 25 of the superintendents (57\%) are wizards, and 19 (43\%) are warriors. Thus, a majority of state leaders who participated in this study are oriented to provide cultural and symbolic leadership as they work to improve the quality of education in West Virginia. According to Bolman and Deal (2006), the wizard inhabits the symbolic frame and possesses behaviors that provide meaning to the organization.

Taking into consideration current state initiatives, such as the integration of $21^{\text {st }}$ century skills into the mastery of standards, leaders must be courageous and confident in embracing change. Research indicates that a higher proportion of wizards would be desirable to lead others to accept change. West Virginia superintendents who demonstrate wizard characteristics display strengths in the areas of interpersonal skills, collaboration, shared leadership, and culture building to enhance an inspirational vision. The higher percentage of wizards, 57\%, in this study suggests that the majority of West Virginia superintendents possess the creativity, vision, and idealism to advance the quality of education into the new century.

This study is the only study in which the wizard image, which inhabits the symbolic frame, dominates Bolman and Deal's wizard and warrior leadership image. Of the 44 West Virginia superintendents who participated in this study, 25 are wizards and 19 are warriors. Although there are no other studies on leadership images and directed modes of thinking using Bolman and Deal's self-inventory survey, there are studies by Bolman and Deal about leadership images that found data that is the reverse of this study. One example is Bolman and Deal's qualitative study (1991) that found that the political frame was the most frequent leadership style for 15 central office administrators from school districts in a Midwestern state (70\%), and the 
symbolic frame was the least frequent leadership style for the central office administrators (5\%). An additional study by Harlow (1994), using Bolman and Deal's frame instrument, found that 20 Washington state public school superintendents rated themselves higher in the political frame than the symbolic frame in critical leadership incident. In Harlow’s study, interview and questionnaire data addressed the frame use of the superintendents. These two aforementioned studies employed Bolman and Deal's frame instrument (which corresponds in part to the wizard and warrior) and found the political or warrior style as predominant. Results from these two studies reveal the underutilization of the positive elements of the wizard leadership style.

Directed Modes of Thinking of West Virginia Superintendents

Research Question 2. What are the temperaments, L-Directed Thinking or R-Directed Thinking, (as measured by the Keirsey FourTypes Sorter) of West Virginia superintendents?

Empirical data reveal that 23 of the superintendents (52\%) are L-Directed Thinking, and 21 of the superintendents (48\%) are R-Directed Thinking. This suggests that the state leaders who participated in this study have a tendency to be L-Directed leaders who rely on their logical, sequential, and analytical thinking skills in administering their responsibilities. A minority of the respondents are R-Directed, although the data is almost evenly distributed. This near balance is consistent with the literature. In this balance, the West Virginia superintendents exhibit logical, sequential, and analytical skills along with R-Directed Thinking skills, inventive, empathetic, and aesthetic. Although individuals may have a preference for L-Directed Thinking or RDirected Thinking, research (Hermann, 1981, Keirsey, 1998, Pink, 2006) shows that all these skills combined are required for organizations to flourish. 
Other studies which examined the directed modes of thinking of school leaders yielded comparable results to this study. For example, Wessman (1988), using the Herrmann Brain Dominance Instrument, found that 232 chief administrators in Michigan were predominantly left brained, illustrating L-Directing Thinking. Farmer (1997), using the Herrmann Brain Dominance Instrument and a Leader Behavior Description Questionnaire, found that the majority of the 33 West Virginia superintendents in her study were predominantly left brained. Norris (1984), using the Herrmann Brain Dominance Instrument and a researcher-designed questionnaire, found that 39 Tennessee superintendents strongly exhibited left brain thinking. Scott-Soler (1991), using the Herrmann Brain Dominance Instrument, found that 197 superintendents from Texas were predominantly left brained. Finally, Ross (1990) found that Arkansas public school superintendents were predominantly left brained. These studies underscore the use of L-Directed Thinking and corroborate this study's data; however, in these studies R-Directed school leaders are in a predominant minority, unlike the higher percentage shown in the West Virginia group (48\%) in this study. Leadership Images and Directed Modes of Thinking

Research Question 3. Is there a statistically significant (> .05) relationship between leadership images and directed modes of thinking?

Although leadership images and directed modes of thinking seem to measure similar styles and orientations, no significant relationship appeared in this study to warrant further analysis. However, it is instructive that an inverse relationship was identified for the two variables among the respondents. The data reveal a higher percentage of wizards and a higher percentage of L-Directed Thinking superintendents, which if statistically significant would indicate a surprising inverse correlation between symbolic and logical tendencies. In practice, 
this would mean that the respondents in this survey who are wizards would exhibit both wizard and L-Directed traits. Thus, research indicates that L-Directed traits are characteristic of the warrior.

Relevant studies have compared L-Directed Thinking, R-Directed Thinking, and leadership domains. Norris (1984) found a relationship between left brained superintendents in Tennessee and a technical leadership style (logical, sequential, analytical), as opposed to a conceptual leadership style (visionary, creative, interpersonal). Additionally, Scott-Soler (1991) found that superintendents in Texas were predominantly left brained and utilized leadership skills of organizing, administering, planning, and controlling. A third study, Ross, 1990, found a significant relationship between predominantly left brained orientation and authoritative leadership in Arkansas superintendents. Furthermore, Norris, Scott-Soler, and Ross found results indicating that left brained leadership is consistently aligned with logical, sequential, and analytical thinking which mirrors L-Directed Thinking. These studies reveal left brain thinking and warrior traits act in tandem, which may suggest that right brain thinking and wizard traits are compatible.

The data in this research may not have found a significant relationship between leadership images and directed modes of thinking because of the small sample size; however, 77 percent of the superintendents possess a combination of wizard or R-Directed Thinking characteristics. The data in this research assists in the identification of characteristics of the current superintendents serving West Virginia school systems. Recognition of these characteristics may assist leaders to identify their own strengths, weaknesses, opportunities, and threats. Once these leadership style preferences have been identified, superintendents may 
employ selected strategies to enhance their skills to lead their school systems successfully into the new century.

Demographic Effect on Leadership Images

Research Question 4. Are there statistically significant (> .05) differences in leadership images of West Virginia superintendents by gender (male or female), size of the student population in the school system (small $=$ less than 3000/medium $=3000-6000 /$ large $=$ more than 6000), the student free and reduced status of the school system (low = less than $50 \% /$ medium $=50 \%-60 \% /$ high $=$ more than $60 \%)$, the number of years as the superintendent (emergent $=0-5$ years $/$ mid-career $=6-10$ years/established $=$ more than 10 years), the superintendent's number of years in the school system (emergent $=0-5$ years/mid-career $=6$-10 years/established $=$ more than 10 years) and the superintendent's number of years of experience in education (emergent $=0-5$ years $/ \mathrm{mid}$ career $=6-10$ years/established $=$ more than 10 years $) ?$

None of the demographic variables concerning gender, size of school system, and the number of years as the superintendent were significant to the leadership images of West Virginia superintendents; however, other studies have yielded pertinent information about the relationship between such variables and leadership. Frick (1996) revealed a significant difference in superintendents’ leadership orientations based on gender in Southern California public school superintendents serving districts with 30,000 or less students. The study showed that females were more oriented to the symbolic frame, and males were more oriented to the political frame. A $76 \%$ response rate was obtained from the sample of 150 of the total 219 superintendents. The survey instruments used were the Leadership Orientations-Self-Questionnaire by Bolman and Deal and a researcher-constructed questionnaire about superintendents' perceptions of change in 
their school districts. On the other hand, Thompson's (2000) study relied on a sample of 57 educational leaders located in a major metropolitan area with 472 subordinate participants who provided perceptions of the leadership styles using Bolman and Deal’s Self-Inventory. In regard to gender, Thompson (2000) found no statistical significance between leadership images and gender.

The size of the school system appears to have no statistical relationship on the leadership images of the superintendents in West Virginia. However, in a study that accounted for the size of the school system, Frick (1996) found that superintendents from Southern California public schools serving medium-size districts (3,000 to under 12,000 total students) exhibited the political frame as the strongest orientation frame. Thus, the size of the school system does not seem to impact leadership images.

The present data in this study suggests little relevance regarding the number of years the superintendents have administered their school systems and leadership images. A study by Harlow (1994) indicates that more experienced leaders were more likely to use the political frame in describing a leadership incident. A study by Frick (1996) reveals a correlation between superintendents' leadership orientations and years of experience as a superintendent in Southern California public schools. The study showed that superintendents with medium experience (5 to less than 10 total years) were more oriented to the symbolic frame.

In summary, the data in this study do not allow any conclusions based on leadership images and demographic variables like gender, size of the school system, and number of years as the superintendent.

Demographic Effect on Directed Modes of Thinking

Research Question 5. Are there statistically significant (> .05)differences in the directed 
modes of thinking of West Virginia superintendents by gender (male or female), size of the student population in the school system (small = less than 3000/medium $=3000$ 6000/large $=$ more than 6000), the student free and reduced status of the school system (low $=$ less than $50 \% /$ medium $=50 \%-60 \%$ / high $=$ more than $60 \%)$, the number of years as the superintendent (emergent $=0-5$ years $/$ mid-career $=6-10$ years $/$ established $=$ more than 10 years), the superintendent's number of years in the school system (emergent $=0-5$ years $/$ mid-career $=6-10$ years $/$ established $=$ more than 10 years $)$ and the superintendent's number of years of experience in education (emergent $=0-5$ years $/$ mid-career $=6-10$ years/established $=$ more than 10 years $) ?$

None of the demographic variables had a significant correlation with respect to the directed modes of thinking of West Virginia superintendents, with the exception of gender. Similar findings were reported in Scott-Soler's (1991) study, in which significant differences were found across brain dominance scores and gender for selected school superintendents in Texas. Female superintendents from school districts throughout the state of Texas revealed a holistic brain dominance profile. Although Norris (1984) found superintendents in Tennessee to be strongly oriented toward left brain, female superintendents were more whole-brained. According to Hermann (1981), a holistic brain and whole-brained are defined as the left brain and right brain working together. The Hermann Brain Dominance Instrument was used in ScottSolar's and Norris' study. Thus, the directed modes of thinking of superintendents appear to be related to gender. What does this mean for West Virginia? One conclusion is that female superintendents in West Virginia have leadership qualities that may facilitate and inspire change since the research data support that the majority of the female superintendents are R-Directed Thinking. Female superintendents who are R-Directed bring inventive, empathetic, and aesthetic 
skills which complement systems that are primarily logical, sequential, and analytical, and such skills are constructive attributes in embracing change.

Even though results from this study do not confirm a statistically significant relationship between directed modes of thinking and size of student population, student free and reduced status, and number of years as superintendent, other research has found correlation between directed modes of thinking and these variables. In regard to size of student population, a study of selected school superintendents in Texas by Scott-Soler (1991) found a correlation between superintendent brain dominance and school district size. Furthermore, the study revealed that the left brain leadership style of superintendents was more dominant in smaller school districts. Another study, Riggs (1991), did not find a significant relationship between left or right brain superintendents from Indiana and the size of school districts. The study did indicate that regardless of left or right brain dominance or size of the school district, the superintendents have adapted their leadership style to meet the needs of their school systems. Only $25 \%$ of the superintendents from Indiana participated in Riggs' study. The superintendents completed a leadership behavior questionnaire and a style of learning questionnaire. It is unclear from the research cited whether school size impacts the directed modes of thinking of public school superintendents.

Results from this study do not confirm a statistically significant relationship between directed modes of thinking and number of years as superintendent. Similarly, a study by ScottSoler (1991) reveals that there is no significant difference in brain dominance for administrative experience. Thus, the number of years as superintendent appears not to impact directed modes of thinking. 


\section{Qualitative Survey Questions}

In addition to the Leadership Self-Inventory Instrument (Bolman \& Deal, 2006) and Keirsey’s FourTypes Sorter (Keirsey, 1988), five survey questions were asked of the respondents. The survey questions provided additional data that allow for the comparison of responses between wizards, warriors, L-Directed Thinking, and R-Directed Thinking leaders. Thus, common themes emerged from the five survey questions. The commonality of these responses may be the result of current systemic changes in education in West Virginia, including increased rigor and relevance in content standards, the Partnership for $21^{\text {st }}$ Century Skills, transition to standards-based instruction, and increased use of formative assessments to balance summative data. As a result of these initiatives, current West Virginia superintendents may develop leadership skills required to lead in a time of significant change.

The responses to the five survey questions indicate the importance of a clear vision and understanding of the organizational demands necessary to pursue and to achieve that vision. With vision as the focal point, the respondents utilize wizard traits to inspire others to implement necessary changes. Superintendents acting as wizards parallel the five practices of leadership: model the way, inspire a shared vision, challenge the process, enable others to act, and encourage the heart as defined by Kouzes and Posner (2007). These wizard behaviors inspire dynamic changes in school systems as administrators prepare students to meet the challenges in a changing and increasingly diverse global economy.

Today, superintendents inspire their vision by utilizing many forms of communication. The advancement of technology has afforded superintendents the opportunity to expand their methods of communication by using email, blogs, the internet, and video conferencing to share 
their message with staff and the community. Clearly, all superintendents continue to use conventional face-to-face meetings to communicate their vision of the school district.

Student success served as a motivating factor for superintendents in West Virginia. This is not surprising considering that most superintendents identified student learning as a critical part of their vision. The superintendents support improved student learning and achievement through actions such as selecting research-based instructional programs, offering timely and relevant professional development for teachers, and allocating financial resources to support teaching and learning that are aligned to the system's vision.

In addition to creating, sharing, and implementing a vision, superintendents are adapting to organizational changes (Carter, Glass, \& Hord, 1993; Hord, 1990; Lashway, 2002; Petersen, 1999; Rammer, 2007). Herrmann (1981) indicates that for the majority, the left brain and the right brain work together, but one side clearly is dominant. Pink (2006) concurs that $21^{\text {st }}$ century leaders complement L-Directed Thinking with R-Directed Thinking. West Virginia superintendents utilize R-Directed Thinking and wizard characteristics in adapting to change in their school systems. Thus, shared leadership, creativity, and enthusiasm motivate others to embrace and follow the change process.

\section{Implications}

The literature indicates that the characteristics of wizards and warriors contribute to effective leadership. "Leaders who balance their inner warrior and wizard can provide leadership that makes a real and positive difference” (Bolman \& Deal, 2006, p. 7). As school systems change to adapt to a changing global environment, superintendents complement their sequential and analytic skills with creative and visionary skills to inspire that necessary change. The superintendents' awareness of their images and directed modes of thinking allows them to 
understand their leadership styles and the characteristics necessary to effectuate change (Lynch, 1986).

Implications for Educational Leaders

Wizard superintendents in West Virginia will promote the transformation of their school systems to adapt to the demands of the $21^{\text {st }}$ century. Wizards initiate measures that help boards of education and administrators break from previously ineffective procedures and to overcome challenges associated with present initiatives as they move forward into a meaningful $21^{\text {st }}$ century educational world (Bolman \& Deal, 1999).

Effectuating change is not a straight-line process (Fullan, 2001; Marx, 2006). Superintendents who display the characteristics of wizards inspire followers to create an educational system that prepares students for success in a dynamic and changing economy. Because change is not straight forward, "Wizards bring imagination, insight, creativity, vision, meaning, and magic to the work of leadership” (Bolman \& Deal, 2006, p. 21).

Superintendents who are wizards seek opportunities to improve their school systems in creative, inspiring, and interpersonal methods and venues. For example, wizards may choose the venue of professional learning communities to promote leadership in schools. The professional learning communities support reflection and the encouragement of new teaching and learning practices. Principals and teachers participating in these communities discuss the virtues and risks of the proposed change, share vision, and contribute to a district-wide commitment to student learning. Reflective practice allows educators to evaluate fully the impact of the proposed change and, therefore, validates its importance.

The wizard superintendent uses symbolic and creative measures to inspire other administrators to create professional learning communities. Through collaboration, 
interdependence, capacity building, and shared knowledge, wizards forge commitment to the change, not force the change (Kouzes \& Posner, 2007). Predictable actions of the wizard superintendent are as follows: support principals in establishing meeting dates and times, support learning communities in designing agendas based on the needs of teachers and students, support learning communities in developing their own norms and gathering their own work products, and support learning communities in the analysis of results. The superintendent then receives feedback from the various learning communities in a meaningful format that focuses upon improved student achievement.

The West Virginia female superintendents possess predominantly wizard characteristics. They have a heightened capacity to lead using symbolic and creative means to inspire commitment to essential changes. Their ability to empathize and to encourage the heart builds essential bonds that persuade others to follow.

Wizards leading as change agents are visible to stakeholders; thus, their visibility creates a culture of support. Administrators may be uncertain and lack confidence in the proposed change of their work; however, the superintendent's presence reassures those administrators that they are not working in isolation. Wizards are able to form relationships, build emotional bonds, and inspire others to overcome obstacles to change (Bolman \& Deal, 2006).

\section{Implications for State Educational Organizations}

Results of this study should be informative and of considerable interest to West Virginia State Superintendent Paine as he and the West Virginia Department of Education work with local superintendents to advance the quality of education in West Virginia, and a letter of support for this study from Superintendent Paine is attached as Appendix J. The data reveal that current public school superintendents in West Virginia may be wizards, warriors, L-Directed Thinking, 
or R-Directed Thinking; however, all West Virginia superintendents must have a balance of wizard, warrior, R-Directed Thinking, and L-Directing Thinking characteristics in order to assure that their systems flourish and adapt in a dynamic world. The responses to the qualitative questions indicate that the superintendents have a collective understanding of these leadership images and directed modes of thinking.

Currently, the majority of the West Virginia female superintendents are wizards and the majority of the West Virginia female superintendents are R-Directed Thinking. Their leadership traits are invaluable as we move from the Information Age to the Conceptual Age.

The results of this study may be of direct interest to the West Virginia School Boards Association in their assessment of and search for future superintendents. Research on leadership images and directed modes of thinking may be used by the Director of the West Virginia School Boards Association in defining leadership characteristics for local boards of education.

Furthermore, the findings and research of this study may be used in developing interview questions for superintendent candidates.

Research by Carter, Glass, and Hord (1993), shows that the continuous improvement of a school system is dependent in large measure upon the competency of the superintendent, so local boards would benefit from this research. Implementing the $21^{\text {st }}$ Century Content Standards and Objectives for West Virginia Schools requires the superintendent to exhibit leadership skills beyond the traditional management of academic performance, and local boards need to be cognizant of this. According to Zhao (2007), educational leaders must become less focused on test scores and more focused on creativity. 


\section{Implications for Policy Makers}

This study may also be useful to state policy makers in regulating the training programs of superintendents. Leaders should be cognizant of all temperaments defined by Keirsey (1998) in order to understand their own strengths and weaknesses. According to Keirsey (1998), all four temperaments are imperative for school administrators to effectuate change in their organization. Findings show that administrators' knowledge of the Keirsey temperaments may enhance the supportive relationship between leaders and followers, and this will lead to increased cohesiveness in school administration (Neundorf, 2007).

West Virginia educational leaders are currently developing a leadership program, West Virginia Leadership Development and Support Collaborative, for superintendents. Policy makers will have the opportunity to review this program with the option of making it a requirement for all West Virginia superintendents.

Implications for Leadership Training

Administrative leaders in higher education may integrate the teaching of leadership images and directed modes of thinking into undergraduate and graduate programs. This study may, therefore, assist those who are preparing to become superintendents by becoming a fundamental part of the new leadership standards for all levels of educational preparation in West Virginia.

The West Virginia University $21^{\text {st }}$ Century Superintendency Certification Program and Educational Leadership Studies Programs may use this research as they prepare students to become superintendents. Students in these programs of study may be presented case studies that require the utilization of wizard, warrior, L-Directing Thinking, and R-Directed Thinking characteristics for analyses and discussions. Problem-based learning scenarios will require 
participants to solve the case studies utilizing leadership skills. For example, problem-based scenarios could include leadership skills needed to create change, address conflict, inspire others, and form relationships.

This study would also be applicable to the development of leadership training programs focusing on the leadership behaviors of school superintendents as they prepare students for the diverse economy and society of the $21^{\text {st }}$ century. Zhao (2006) shows that educators must strive not to stagnate the imagination and creativity of their students, and superintendents must lead their school systems to assure that students are able to compete in a global economy. Professional development, training, and awareness of leadership images and directed modes of thinking may assist superintendents in meeting this challenge.

Based on this study, the West Virginia Superintendent Conferences may conduct leadership image and brain dominance training for superintendents to promote the development of whole-brain leadership. Also, the West Virginia Administrators and Superintendents Association (WVASA) may rely on this study to support continuing professional development for their membership.

Professional development may include such activities as having the superintendents complete the Bolman and Deal's Leadership Self-Inventory and Keirsey’s FourTypes Sorter in order to identify their own strengths, weaknesses, opportunities, and threats. Their selfevaluation will create an awareness of their leadership styles as well as an understanding of other leadership traits. Additionally, in order to enhance their leadership effectiveness, they may use this knowledge to develop leadership teams with complementary skills. 


\section{Implications for Further Research}

Research (Bolman \& Deal, 2006; Farmer, 1997; Hermann, 1981; Pink, 2006) suggests that to create and to articulate an instructional vision for school systems, the skills associated with wizards, warriors, L-Directed Thinking, and R-Directed Thinking are all necessary. If this study were conducted allowing the subordinates in the school districts to determine whether their superintendents were wizards, warriors, L-Directed Thinking, and R-Directed Thinking, the results may be confirmed or may be contradicted.

Research (Bolman \& Deal, 2003; Hersey, Blanchard, \& Johnson, 1996) also suggests that situational leadership exists among school systems. Hersey and Blanchard (1996) define four possible leadership styles: telling, selling, participating, and delegating. Thus, leadership style may be determined by the personalities of subordinates. The leadership images and directed modes of thinking of the superintendents in this study may be a result of the subordinates they are leading.

By confirming a statistical correlation between directed modes of thinking and gender, this study has advanced the learning regarding leadership and gender. Pink (2006) introduced empathy as an essential aptitude to the development of a new mind in the Conceptual Age, and the principle of empathy was so important to Pink's thinking that he referred to empathy as the sixth sense. Other research (Bolman \& Deal, 2003; Pink, 2006) shows that females are more likely than males to sense what others are thinking and feeling. Furthermore, Pink (2006) states that there are more male brains that systemize than female brains, which is characteristic of LDirected Thinking. Additionally, more female brains empathize than male brains, which is characteristic of R-Directed Thinking. Therefore, according to Pink (2006), leaders who are able 
to adapt their brains both to systemize and to empathize will be at a tremendous strategic advantage in the future.

\section{Recommendations for Further Research}

This study suggests that additional research is necessary to determine the relationship between leadership images and directed modes of thinking. Recommendations for further research include:

1. Apply the means of this study to a larger population. This could involve the public school superintendents from states bordering West Virginia, such as Kentucky, Maryland, Ohio, Pennsylvania, and Virginia. A larger population may reveal a significant relationship between leadership images and directed modes of thinking.

2. Conduct research using Bolman and Deal's Leadership Images Self-Inventory and Bolman and Deal's Frame Instrument to determine if there is a significant relationship between leadership images and the four frames.

3. Repeat this study allowing subordinates to identify whether the superintendents are wizards or warriors. The researcher will construct an instrument that will allow subordinates to identify whether the superintendents are wizards or warriors.

4. Conduct this study one year later. In May 2009, a new state test, West Virginia Educational Standards Test 2 (WESTEST 2), will be administered to students in grades $3-11$. The test will be based on the $21^{\text {st }}$ Century Content Standards and Objectives for West Virginia Schools. The new standards encourage students to work both independently and collaboratively using critical thinking and problem solving skills necessary for the $21^{\text {st }}$ century. These standards became effective for the school 
year 2008-2009, and as a result the characteristics of leaders may change as they implement a curriculum with more rigor and relevance.

5. Conduct research using qualitative design to examine the relationship between leadership images and directed modes of thinking on the current West Virginia female superintendents. Currently, the state has19 female superintendents, and 18 of them participated in this study.

6. Conduct further research on gender and directed modes of thinking as it pertains to leadership.

7. Conduct case studies on superintendents of exemplary school systems as measured by the No Child Left Behind Legislation (NCLB). Specific leadership images and directed modes of thinking may identify and contribute to leadership that promotes excellence.

8. Conduct studies using qualitative design to examine the relationship between leadership images and directed modes of thinking for all superintendents in West Virginia. Personal interviews with superintendents may reveal specific behaviors related to wizards, warriors, R-Directed Thinking and L-Directed Thinking leadership.

9. Conduct studies using mixed methods research to examine the relationship between leadership images and directed modes of thinking. Specific responses from the superintendents as well as statistical analysis may produce meaningful data. 


\section{References}

American Association of School Administrators. (2007, September 24). Study of the American school superintendency. Retrieved October 29, 2008, from http://www.aasa.org/newsroom/pressdetail.html

Athans, S. L. (2000). Temperament and competence in the managerial roles of community college presidents. Dissertation Abstracts International, 61, 12A. (UMI No. 4639)

Baron, R. (1998). What type am I: Discover who you really are. New York, NY: Penguin Group. Bassett, P. F. (2005). Reengineering schools for the $21^{\text {st }}$ century. Phi Delta Kappan, 87(1), 7683.

Bensimon, E. M. (1989). Making sense of administrative leadership. Washington, DC: Clearinghouse on Higher Education. (ERIC Document Reproduction Service No. ED 317099)

Blumberg, A. (1985). The school superintendent: Living with conflict. New York, NY: Teachers College Press.

Bolman, L. G., \& Deal, T. E. (1991). Images of leadership. (Report No. 7). Nashville, TN: National Center for Educational Leadership. (ERIC Document Reproduction Service No. ED 332345).

Bolman, L. G., \& Deal, T. E. (1999). Steps to keeping change efforts heading in the right direction. The Journal For Quality \& Participation, 7-11.

Bolman, L., \& Deal, T. (2003). Reframing organizations: Artistry, choice, and leadership. San Francisco, CA: Jossey-Bass.

Bolman, L., \& Deal, T. (2006). The wizard and the warrior: Leading with passion and power. San Francisco, CA: Jossey-Bass. 
Bolman Deal, B. (2006). Bolman leadership. Retrieved June 11, 2008, from http://www.leebolman.com/leadership_research.htm

Bottoms, G. (1991). Reaching the goal to reduce the dropout rate. Atlanta, Georgia: Southern Regional Education Board.

Bottoms, G. (2001). Things that matter most in improving student learning: Implications for state policy and educational leadership. Atlanta, Georgia: Southern Regional Education Board.

Bracey, G. W. (2002). The $12^{\text {th }}$ Bracey report on the condition of public education. Phi Delta Kappan, 84(2), 135-150.

Bracey, G. W. (2007). Skills for the future. Phi Delta Kappan, 89(1), 77-78.

Bracey, G. W. (2008). Competing Concepts of Competitiveness. Phi Delta Kappan, 90(4), 620621.

Bredeson, P. V. (1995, April). Superintendents’ roles in curriculum development and instructional leadership: Instructional visionaries, collaborators, supporters, and delegators. Paper presented at the annual meeting of the American Educational Research Association, San Francisco, CA. (ERIC Document Reproduction Service No. ED 390143)

Brown, F. \& Hunter, R. C. (1986, April). A model of instructional leadership for school superintendents. Paper presented at the annual meeting of the American Educational Research Association, San Francisco, CA. (ERIC Document Reproduction Service No. ED 271864)

Bruer, J. (1999). In search of...brain-based education. Phi Delta Kappa International. 80(9). Retrieved March 3, 2008, from http://www.pdkintl.org/kappan/kbru9905.htm 
Burnett, R. D. (1989). The effects of superintendents’ leadership behaviors in curriculum and instruction upon student achievement in South Carolina public school districts. Dissertation Abstracts International, 50, 06A. (UMI No. 1494)

Carter, D., Glass, T. E. \& Hord, S. (1993) Selecting, Preparing and Developing the School District Superintendent. (ERIC Document Reproduction Service No. ED 393215)

Castagnola, J. R. (2005). The role of the superintendent of schools in improving student achievement. Dissertation Abstracts International, 66, 12A. (UMI No. 4248)

Center for Educational Leadership. Getting Accountability and School Improvement on Track in Texas: A Report by the School Superintendents of Bexar County. San Antonio, TX, 1993.

Cherniss, C. (1998, April). Social and emotional learning for leaders. Educational Leadership, 55(7), 26-28.

Clark, R. C. (2004). Successful practices of successful superintendents. Dissertation Abstracts International, 65, 01A. (UMI No. 30)

Collavo, L. E. (2002). A study of factors associated with gender-specific superintendents in Texas public schools. Dissertation Abstracts International, 63, 12A. (UMI No. 4162)

Crane, T. (Ed.). (2002). Critical elements for creating $21^{\text {st }}$ century skills. Washington: Partnership for $21^{\text {st }}$ Century Skills.

Crowson, R. L., \& Morris, V. (1990). The superintendency and school leadership. Urbana, IL: The National Center for School Leadership Project Report. (ERIC Document Reproduction Service No. ED 328945)

Daggett, W. (2005). Achieving academic excellence through rigor and relevance. International Center for Leadership in Education, Rexford, NY.

Dobbs, W. J. (2004). Implementing the state standards for student achievement: Superintendent 
perspectives. Dissertation Abstracts International, 65, 02A. (UMI No. 361)

Dowd, J. F. (1991). School superintendents' perceptions of conflicts and how they deal with them (conflict management). Dissertation Abstracts International, 53, 04A. (UMI No. 0999)

Durow, W. P. (1987). Ambiguity tolerance and intuition in the management styles of selected Iowa school administrators. Dissertation Abstracts International, 48, 05A. (UMI No. 1068)

Farmer, T. S. (1997). The relationship between brain hemispheric characteristics and leadership style of school superintendents in West Virginia. (Doctoral Dissertation, West Virginia University, 1997). (UMI No. 9722175)

Faverty, P. W. (1997). A causal-comparative study of the effects of the ACSA small school district superintendents academy of the leadership orientation of California superintendents. Dissertation Abstracts International, 58, 11A. (UMI No. 4136)

Flack, T. M. (1998). An inquiry into the leadership orientations of selected women school superintendents (women superintendents, Lee Bolman, Terrance Deal). Dissertation Abstracts International, 60, 02A. (UMI No. 0293)

Flew, T. (2004). Creativity, the "new humanism” and cultural studies. Journal of Media \& Cultural Studies, 18(2), 161-178.

Frick, D. R. (1996). A causal-comparative study of the leadership orientation frames of superintendents and their perceptions about educational change. Dissertation Abstracts International, 57, 04A. (UMI No. 1412)

Fullan, M. (2001). Leading in a culture of change. San Francisco, CA: Jossey-Bass. Fullan, M. (2003). The moral imperative of school leadership. Thousand Oaks, CA: Corwin 
Press, Inc.

Funk, C., Pankake, A. \& Schroth, G. (2002). Archetypes of outstanding female superintendents. Huntsville, TX: Teacher Education Center Department of Educational Leadership and Counseling. (ERIC Document Reproduction Service No. ED 481622)

Goldman, E. (1998, April). The significance of leadership style. Educational Leadership, 55(7), 20-22.

Guilfoyle, C. (2006, November). NCLB: Is there life beyond testing? Educational Leadership, 64(3), 8-13.

Harlow, J. H. (1994). Educational leadership: A frame analysis. Dissertation Abstracts International, 55, 08A. (UMI No. 2227)

Herrmann, N. (1981). The creative brain. Training and Development Journal, 16(3), 11-16.

Hersey, P. \& Blanchard, K. (1996, January). Great ideas. Training \& Development, 42-47.

Hersey, P., Blanchard, K., \& Johnson, D. (1996). Management of organizational behavior. Upper Saddle River, NJ: Prentice-Hall, Inc.

Hinkle, D. E., Wiersma, W., \& Jurs, S. G. (2003). Applied statistics for the behavioral sciences. Boston, MA: Houghton Mifflin.

Hord, S. M. (1990). Images of superintendents’ leadership for learning. (Contract No. 400-860008). Austin, TX: Southwest Educational Development Lab. (ERIC Document Reproduction Service No. ED 355652)

Hoy, W. K., \& Miskel, C. G. (2005). Educational administration: Theory, research, and practice. New York: McGraw-Hill.

Hughes, W. H., (1992). Approaches superintendents use to establish relationships with their boards of education (board superintendent relationships). Dissertation Abstracts 
International, 53, 07A. (UMI No. 2184)

Johnson, G. L. (2007). A study of the relationships between community power structures, school board types, superintendent leadership styles and the impact on student achievement in Oklahoma. Dissertation Abstracts International, 68, 04A. (UMI No. 1251)

Johnson, Jr., J. F., \& Uline, C. L. (2005). Preparing educational leaders to close achievement gaps. Theory Into Practice. 44(1), 45-52.

Judson, E., Schwartz, P., Allen, K., \& Miel, T. (2008). Rescuing distressed schools. American School Board Journal, 42-43.

Keirsey, D. (1998). Please understand me II: Temperament character intelligence. Del Mar, CA: Prometheus Nemesis Book Company.

Keirsey, D., \& Bates, M. (1984). Please understand me: Character \& temperament types. Del Mar, CA: Prometheus Nemesis Book Company.

Kohn, G. W. (1984). Reorganization in public high schools: Two studies of educational leadership (superintendent). Dissertation Abstracts International, 45, 06A. (UMI No. 1593)

Kouzes, J. \& Posner, B. (2003). The leadership challenge journal. San Francisco, CA: JosseyBass.

Kouzes, J. \& Posner, B. (2007). The leadership challenge. San Francisco, CA: Jossey-Bass.

Kowalski, T. (2005). Evolution of the school district superintendent position. Retrieved June 4, 2008, from http://homepages.udayton.edu/ kowalstz/books.htm

Lane, M. A. (2006). No child left behind: Implementation challenges for the rural public school district superintendent. Dissertation Abstracts International, 67, 09A. (UMI No. 3247)

Lashway, L. (1995). Can instructional leaders be facilitative leaders? Eugene, OR: 
Clearinghouse on Educational Management. (ERIC Document Reproduction Service No. ED381893)

Lashway, L. (1996). The strategies of a leader. Eugene, OR: Clearinghouse on Educational Management. (ERIC Document Reproduction Service No. ED406718)

Lashway, L. (2002). Developing instructional leaders. Eugene, OR: Clearinghouse on Educational Management. (ERIC Document Reproduction Service No. ED466023)

Lashway, L. (2002). The superintendent in an age of accountability. Eugene, OR: Clearinghouse on Educational Management. (ERIC Document Reproduction Service No. ED468515)

Lashway, L. (2003). Developing instructional leaders. Retrieved May 20, 2008, from http://www.ericdigests.org/2003-2/leaders.html

Lynch, D. (1986, February).Is the brain stuff still the right (or left) stuff. Training and Development Journal. 40(2), 22-26.

MacNeill, N., Cavanagh, R., \& Silcox, S. Beyond instructional leadership: Towards pedagogic leadership. Paper submitted for presentation at the annual conference of the Australian Association for Research in Education: Auckland, New Zealand, 2003.

Manzo, K. K., \& Cavanagh, S. (2008). America Scouts Overseas to Boost Education Skills. Education Week, 27(34), 14-16.

Marlatt, S. G. (2004). Characteristics of superintendents who are effective instructional leaders (California). Dissertation Abstracts International, 65, 07A. (UMI No. 2444)

Marx, G (2006). Sixteen trends: Their profound impact on our future. Alexandria, VA: Educational Research Service.

Marzano, R. J., Waters, T., \& McNulty, B. A. (2005). School leadership that works. Alexandria, VA: Association for Supervision and Curriculum Development. 
Mathis, W. (2005).Bridging the achievement gap: A bridge too far? Phi Delta Kappan. 86(8), 590-593.

McCartney-Infelise, R. M. (1999). A study of the leadership orientations of MAIS school directors and a comparison of their leadership orientations with those of small school district superintendents in California. Dissertation Abstracts International, 60, 05A. (UMI No. 1411)

Miners, Z. (2007, November). New report illuminates the superintendency. District Administration, 14.

Mintzberg, Henry. (1983). The power game and the players. In Jay M. Shafritz, J. Steven Ott, \& Yong Suk Jang (Eds.), Classics of organization theory $\left(6^{\text {th }}\right.$ ed.) (pp. 334-341). Belmont, CA: Thomson Wadsworth.

Muller, R. W. (1989). Instructional leadership superintendent competencies related to student achievement. Dissertation Abstracts International, 50, 09A. (UMI No. 2737)

Murphy, J. \& Hallinger, P. (1988). Characteristics of instructionally effective school districts. Journal of Educational Research. 81(3), 175-181.

Neundorf, D. (2007). Pharmaceutical science leaders and the staff members who support them: Exploring differences in Myers-Briggs Type and Keirsey temperament. Dissertation Abstracts International, 68, 01A. (UMI No. 70)

Norris, C. J. (1984). A discussion of brain hemisphere characteristics and creative leadership among selected educational administrators in Tennessee. Dissertation Abstracts International, 45, 11A. (UMI No. 3256)

Paine, S. L. (2002). The relationship of superintendent instructional leadership behavior and student achievement in high performing high schools that work network public high 
schools in West Virginia. Unpublished doctoral dissertation, West Virginia University, West Virginia.

Pascopella, A. (2008, February). State of the superintendency. District Administration, 32-36.

Petersen, G. (1999). Demonstrated actions of instructional leaders: an examination of five California superintendents. Education Policy Analysis Archives, 7, Retrieved April 4, 2008, from http://epaa.asu.edu/epaa/v7n18.html

Pink, D. (2006). A whole new mind. New York, NY: The Berkley Publishing Group.

Polacheck, K. N. (2006). Effective superintendent - district board team leadership in large urban districts to improve student achievement. Dissertation Abstracts International, 67, 07A. (UMI No. 2414)

Rammer, R. A. (2007).Call to action for superintendents: Change the way you hire principals. The Journal of Educational Research, 101(2), 67-76.

Rammer, R. A. (2007). How do superintendents consider the responsibilities associated with effective public school principals, as identified in the literature and correlated with student achievement, when hiring principals? Dissertation Abstracts International, 68, 04A. (UMI No. 1260)

Riggs, L. D. (1991). The relationship of leadership styles and brain dominance of school superintendents in small, medium, and large school settings (school district size). Dissertation Abstracts International, 52, 11A. (UMI No. 3791)

Ross, H. R. (1990). A study of the relationship of left and right brain dominance to leadership styles of public school superintendents in Arkansas. Dissertation Abstracts International, 52, 02A. (UMI No. 0379)

Schlechty, P. (1997). Inventing Better Schools. San Francisco, CA: Jossey-Bass Inc. 
Schoo, A. (2008). Leaders and their teams: Learning to improve performance with emotional intelligence and using choice theory. International Journal of Reality Theory, 27(2), 4045.

SchoolDataDirect - United States Public Schools, Public School Districts - Overview. Retrieved October 31, 2008, from http://www.schooldatadirect.org/app/printfriendly/q.html

Schwahn, C. \& Spady, W. (1998, April). Why change doesn’t happen and how to make sure it does. Educational Leadership, 55(7), 45-47.

Scott-Soler, E. I. (1991). Brain hemisphere characteristics and leadership style of selected school superintendents in Texas. Dissertation Abstracts International, 53, 03A. (UMI No. 0683)

Sharp, W. L., Malone, B. G. \& Walter, J. K. (2002, October). What motivates someone to become a superintendent? Paper presented at the annual meeting of the Mid-Western Educational Research Association, Columbus, OH. (ERIC Document Reproduction Service No. ED 479 800)

Sherman, W. H., \& Grogan, M. (2003). Superintendents' responses to the achievement gap: An ethical critique. International Journal of Leadership in Education. 6(3), 223-237.

Skarstad, K. G. N. (1994). Reconceptualizing the role of teacher leaders: Collaboration among visionaries, troubleshooters, catalysts and stabilizers. Dissertation Abstracts International, 55, 04A. (UMI No. 0805)

Soares, L. M. \& Soares, A. T. (2000, April). Images of the superintendent. Paper presented at the annual meeting of the American Educational Research Association, New Orleans, LA. (ERIC Document Reproduction Service No. ED 450 467)

Strickland, J. S. (1992). Leadership perspectives of Tennessee school leaders (organizational frames). Dissertation Abstracts International, 53, 04A. (UMI No. 1018) 
Swanson, C. B. (2008).Grading the states. Education Week, 27(18), 36-57.

Thomas, J. (2001). The public school superintendency in the twenty-first century: The quest to define effective leadership. (Report No. CRESPAR-R-55). Baltimore, MD: Center for Research on the Education of Students Placed At Risk. (ERIC Document Reproduction Service No. ED 460 219)

Thompson, L. J. (2006). District leadership practices in curriculum and instruction. Dissertation Abstracts International, 67, 10A. (UMI No. 3678)

Thompson, M. D. “Gender, Leadership Orientation, and Effectiveness: Testing the Theoretical Models of Bolman \& Deal and Quinn.” Sex Roles nos. 11/12 (2000): 969-992.

Trinity University Center for Educational Leadership.(1993). Getting accountability and school improvement on track in Texas: A report by the school superintendents of Bexar County, San Antonio, TX: Superintendents of Bexar County. (ERIC Document Reproduction Service No. ED 368 037)

Wallace, R. (1985). The superintendent of education: Data based instructional leadership. (Report No. LDRC-1985-7). Pittsburgh, PA: Pittsburgh University Learning Research and Development Center. (ERIC Document Reproduction Service No. ED 256060)

Ward, D. E. (2006). Dominant leadership frames of reference for active Indiana public school superintendents. Dissertation Abstracts International, 68, 02A. (UMI No. 432)

Wessman, L. L. (1988). The relationship of brain hemisphere dominance to the professional development of chief educational administrators. Dissertation Abstracts International, 49, 05A. (UMI No. 1030)

Wesson, L. H. \& Grady, M. L. (1994). The leadership challenge: A national study of women superintendents. Paper presented at the Annual Meeting of the American Educational 
Research Association, New Orleans, LA. (ERIC Document Reproduction Service No. ED 375 527)

West Virginia Department of Education, (2006). West Virginia: Closing the Achievement Gap for $21^{\text {st }}$ Century Learners, WVDE Office of Student Assessment Services Division of Curriculum \& Instruction Services.

West Virginia School Laws Annotated, (2007). Charlottesville, VA: LexisNexis Matthew Bender \& Company, Inc.

Wirt, F. M. (1990). The missing link in instructional leadership: The superintendent, conflict, and maintenance. (Report No. RI17C80003). Urbana, IL: Illinois University Beckman Inst. For Advanced Science and Technology. (ERIC Document Reproduction Service No. ED 327945)

Zhao, Y. (2007). Education in the flat world: Implications of globalization on education. Phi Delta Kappa International. 2(4), 3-19. 


\section{LEADERSHIP IMAGES: A LEADERSHIP SELF-INVENTORY Assessing Your Inner Wizard and Warrior}

The "Leadership Images" survey contains twelve items. Each asks you to rank order four different possibilities. Give a 4 to the option that is most like you. Not the one that you like or agree with most, but the one that you think comes closest to describing you. Give a 3 to the one that is next most like you, and on down to 1 for the option that is least like you. Make your best guess and move on.

1. I see myself as

a. Logical

b. Loving

c. Combative

d. Imaginative

2. People would say I am more like

a. A judge

b. A counselor

c. A soldier

d. A poet

3. The career that suits me best is

a. Accounting

b. Teaching

c. Politics

d. Design

4. My strongest skills are

a. Analytic

b. Interpersonal

c. Competitive

d. Artistic 
5. I enjoy spending free time

a. Managing finances

b. Relaxing with family or friends

c. Competing for victory

d. Creating something

6. The best way to describe me is

a. Technical expert

b. Caring listener

c. Tireless competitor

d. Inspirational leader

7. If I had lived five hundred years ago, I think I would have been

a. A Merchant

b. A Shepherd

c. A Warlord

d. A Magician

8. What has helped me be successful is my ability to

a. Make good decisions

b. Help others be their best

c. Win

d. See possibilities others don't see

9. I am

a. A Realist

b. A Humanist

c. A Battler

d. An Idealist 
10. I am best at

a. Clear thinking

b. Caring for others

c. Overcoming opposition

_d. Magic

11. People see me as

a. Organized

b. Kind

c. Courageous

d. Wise

12. I am

a. An Analyst

b. A Caregiver

c. A Warrior

d. A Wizard 


\section{Dlanna M. Vargo}

$\begin{array}{ll}\text { From: } & \text { "Lee Bolman" <bolmanleumkc.edus } \\ \text { To: } & \text { mDlanna M. Vargo"' <ovargogaccess.k12.wr.us> } \\ \text { Sonte } & \text { Monday, February 04, 2008 8:04 PM } \\ \text { Subject } & \text { RE: Permission to use Leaderghip imago instrument }\end{array}$

Dear Ms. Vargo:

I am happy to offer you permission to use the Leadership Orlentations instrument in your dissertation research, subject to the agreement that you outlined in your message.

3est wishes on your research.

Lee G. Bolman

Professor and Marion BlochiMissouri Chair in Leadership

Bloch School of Business and Public Administration

University of Missouri-Kansas City

5100 Rockhill Road

Kansas City, MO 64110

Tel: (816) 235-5407

Fax: (816) 235-6529

Email: bolmani@umkc.edu

:iab 3ife: ww. leebolman. som

From: Dlanna M. Vargo [malto:dvargo(facoss.k12.uv.us]

Sente Monday, February 04, 2008 5:14 PM

To: bolmanl@umkc.edu

Subjecte Permission to use Leadership Image instrument

Dear Dr. Bolman.

I request your permission to use Leadership Images: A Leadership Selt-Inventory instrument as part of my dissertaion entitled "A study of the relationship between the leadership styles of superintendents and their perceptions of the strategic planning process in terms of student achievement, involvement of people, and protessional development in West Virginia school systems."

I am a doctoral candidate at West Virginia University in Educational Leadership Studies. I understand the conditions under which you grant permission such as, the results of my research will be made available to you -spon request.

Dr. Bolman. I have found your work very valuable. It is my hope that you will grant me permission to continue ihis research. Thank you for considering this request.

Sincerely.

Lianna Vargo 
The Kelrseg FourTypes Sorter. Por each item, rank-order the four choicea, Mart the

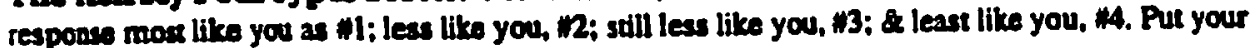
number in frout of the corresponding letters.

1. I'd rather stondy

- (a) arts cterafu

- (b) liternmo a mumanitiea

- (c) busineas $\&$ finance

- (d) sciencs a engineering

2. I leat bext about myall whos

- (a) I'm greceful in action

- (b) I'm en rappon with someone

- (c) I'm rock-solld dependablo

- (d) I exerdice my ingewrity

3. In wood Pow mare ofter

- (a) excited a stimininted

- (b) enthosiastic a inspired

- (c) cautious as poident

- (d) calm a decectied

4. I kew ecantors back to
(a) perfecting wy cran

- (b) helping othen affirm thernselves

- (c) holping othen do righ

- (d) Bguring out how things wort

5. Coming ritht down to It I tend to bo

- (a) practical sopporninistic

- (b) compascionte a altruistle

- (c) chuiful a diligent

(d) efficient a prapmasic

6. I repeat myself oror los
(a) beins bold a adventurous

- (b) being kind hearted $A$ of good will

- (c) doing good deeds

(d) being autonomous a independent

7. I'm mas inclined to trut

- (a) impules a whim

- (b) intuitions a intimations

- (c) curtome traditions

- (d) pure reason \& formal logic

8. I'm sometheres eager to

- (a) make an impression at have impact

- (b) lose myself in romanite dreams

- (c) be a valued \& legitimate member

- (d) make a scientific breakthrough

9. I'm in a life-long search for more

- (a) thrills a adventures

- (b) self-understandine

- (c) safety a security

(d) efficient methods of operation

$\overline{10}$. In fredns the futonre

- (a) I bet something Jucky will tum up

- (b) I belleve in people's innate goodness

- (c) You just can't be too careful

- (d) It's beat to keep a wey cyo

11. If if vere pocibls I'd lits to become

- (a) an artistte vimuoso

- (b) a wise prophes

- (c) a chief executive

(d) a technological genius

12. P'd do beti in a job wortings with

- (a) cools \& equipment

- (b) humen resources development

- (c) materied a services

- (d) systems \& structuren

13. As a guide to acton I look primartly at

- (a) immediabo advantages

- (b) future posaibilities

- (c) past experience

- (d) necessery \& sufficient condition

14. I'm mod self-confident when I'm

- (a) adaptable a flexible

- (b) genuine \& authentic

- (c) honorable a respectable

- (d) strong-willed a resoluto

15. I apprectate it when othern

- (a) suprise me with generosity

- (b) recognize my tue self

- (c) express their gratitude

- (d) ask me for my rationale

16. When thinding about misfortun

- (a) I usually laugh it off

- (b) I often wonder why

- (c) I try to make the beat of it

- (d) I view it from a wide perspective

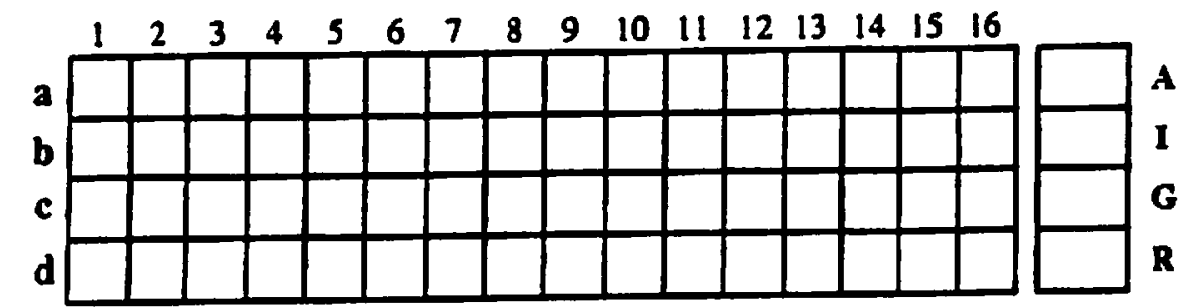

Direedonn for Scorings - Ftrat, in the numbered columns above, record your rankings $(1$ to 4 ) for each of the 16 items. - Second, add the numbers across each of the four rows $(a, b, c, d)$ \& place the sums in the boxes at the far right of the rows. - Third. circle the letter $(A, \mathbb{G}$, or $\mathbf{R})$ beside the iswest sum. - Fourth. A stands for Artisan, I for Idealist, $\mathbf{G}$ for Guardian, $\mathbf{R}$ for Rational. 


\section{Prometheus Nemesis Book Company Order Form www.keirsey.com}

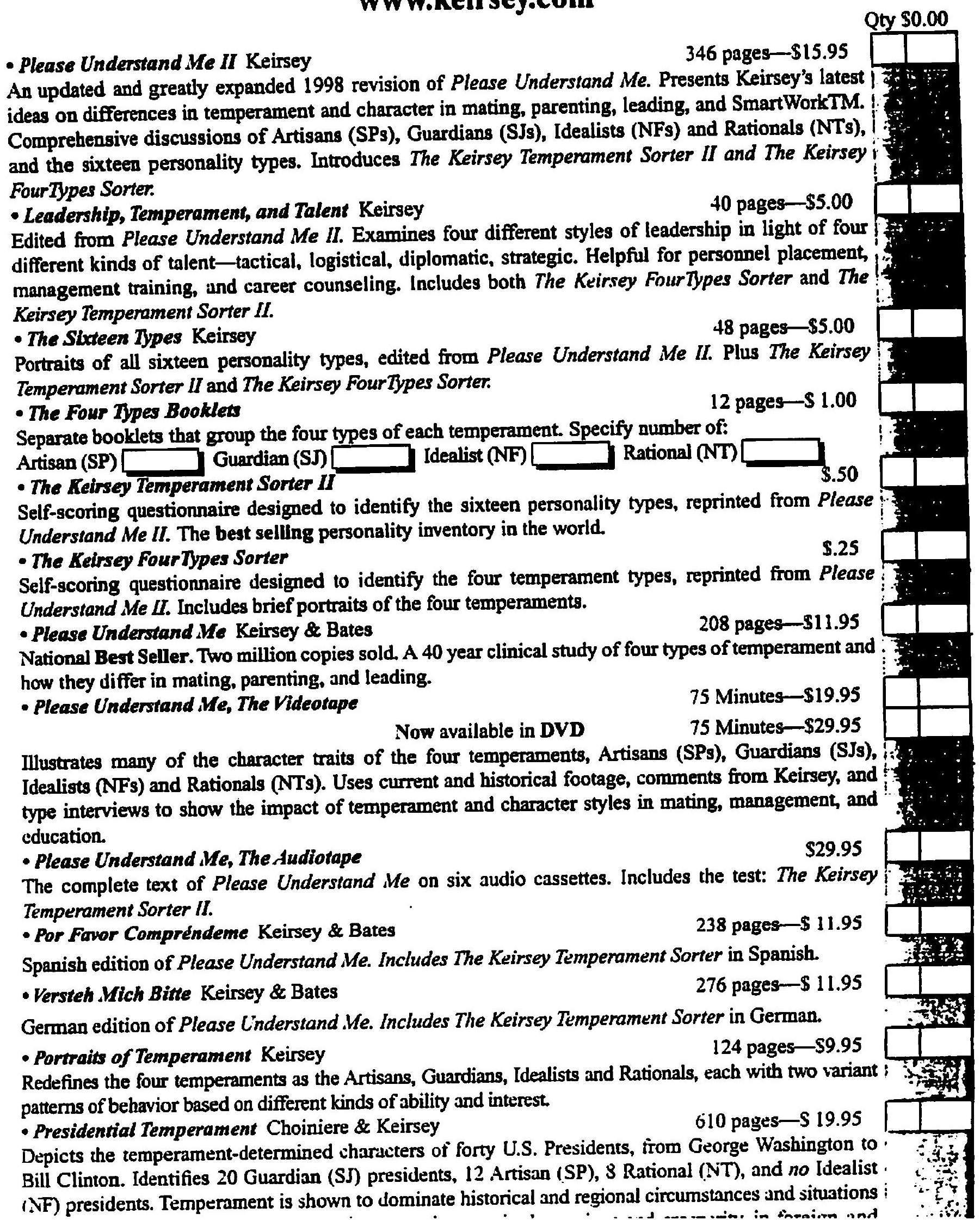




\section{Demographic Information Sheet}

Please check the appropriate response.

1. Gender:

2. Total Years in Education:

3. Total Years at Current School System:

4. Total Years as Superintendent:

5. Size of Student Population:

6. Student Free and Reduced Status:
$\mathbf{M}$

Less than 5

Less than 5

Less than 5

Less than 3000

Less than $50 \%$

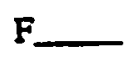

5-10

5-10

5-10

$3000-6000$

$50 \%-60 \%$
More than10

More than 10

More than 10

More than 6000

More than $60 \%$

\section{Please provide a response to each of the five survey questions.}

1. As the superintendent of your school system, what is your vision for the $21^{\text {st }}$ century learner?

2. How will you communicate your vision to the stakeholders in your school system?

3. What work motivates you to create an organizational structure that supports the instructional vision of the school system?

4. How do you assess and evaluate personnel and instructional programs in your school system?

5. What are the common characteristics of the work you do to meet the demands of organizational adaptation?

If you would like to discuss your responses with me, please provide an email address or a telephone number. 
STATE OF WEST VRGINL COUNTY SUPERWTENDENTS - REVISED JUWY 14, 2008

\begin{tabular}{|c|c|c|c|c|c|c|c|c|}
\hline conkm & FHON: & Ex: & FAR: & EmeilAddras & SUPERNIEIDENT & AODRESS & $\mathrm{CITY}$ & ZIP COOE \\
\hline Betoon & 457.3030 & 122 & 457.3559 & 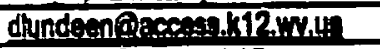 & DeEdu Lundem (D.) & 105 So. Ralifoed SL. & Philippl & $26196-1177$ \\
\hline Bertotol & 267.3500 & 3233 & 287.3513 & mpanonforecen:k12,w1!4 & Manued P. Aron, II & 401 S. Queen Street & Martinaburn & $25401-3226$ \\
\hline Boonen & $369-3131$ & 233 & $362-8789$ & 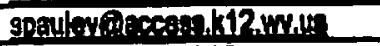 & Stove Peuloy & 69 Avenua $\mathrm{B}$ & Madison & $25130-1198$ \\
\hline Bration & 765.7911 & & 766.7152 & 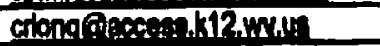 & CardinL Lon & 411 North HII Rosd & Sutton & $26601-1147$ \\
\hline Brooks & 737.3191 & 12 & 737.3400 & 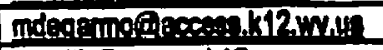 & MeykHervongomo & 1201 Ploasent Are. & Weilobur & $26070-1497$ \\
\hline Cabe & 52360000 & & $528-5034$ & 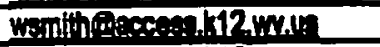 & Willena. Sinth & 2850 Fin Avenue & Hunthoton & $25702-1438$ \\
\hline Cashoun & 3547011 & 17 & 3547420 & 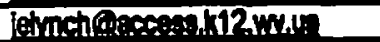 & JaneLrneh & HC \& Box 119 & ML Zon & $26151-9734$ \\
\hline $\mathrm{Cly}$ & $567+268$ & & 5874181 & 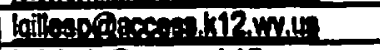 & Lam Gillogon & P.0. $\operatorname{Box} 120$ & Clay & $25043-0120$ \\
\hline Doddridge & $873-2300$ & 18 & 8732210 & 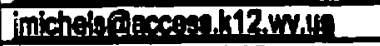 & Janteo Michion & 104 Sistersvilb Pike & West Union & $26456-1099$ \\
\hline Favolth & 5741178 & 2122 & 5743643 & 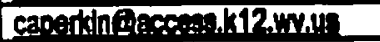 & Chith Penting & 111 Fayolt Avenue & Fayattavilip & $25840-1299$ \\
\hline Glune & 462.7386 & 20 & 462.6103 & 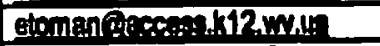 & Edword Tomm & 201 No. Count Streat & Glomvili & 26351.1294 \\
\hline Grat & 257.1011 & 15 & $257-2463$ & 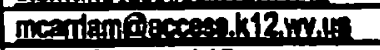 & 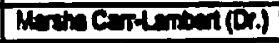 & 204 Lefiferson Averiug & Peteraburg & $26847-1628$ \\
\hline Greanbrise & 6478470 & 58 & 8478490 & 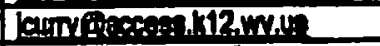 & $\operatorname{senn}$ D. Cury & 202 Chestnd Stree & Lemiabur & $24901-1109$ \\
\hline Hampatire & 822.5058 & 120 & $822-6509$ & 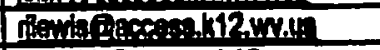 & Roth Low & 46 S. High Strod & Romner & $26757-1852$ \\
\hline Hencoct & 5843411 & 9 & 5643990 & 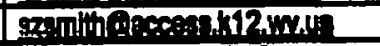 & Suam Smlth & 104N. Count Streot & Noncumbertend & $26017-9521$ \\
\hline Hady & 5302346 & 222 & 530.2340 & 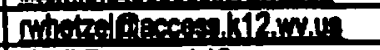 & Roned V. Whoted & 510 Ashby Strect & Mooreffold & $26836-1099$ \\
\hline Hantsen & 326.7342 & & 6243331 & 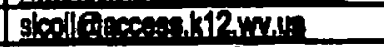 & Susen Lee Colitre & P.0. Bon 1370 & Clatoboun & 26302.1370 \\
\hline Jackeon & 372.7300 & 14 & 372.7312 & bherefecesth12,wn, & Bleln C. Hes & P.0. $\operatorname{Bon} 770$ & Riploy & $25271-0770$ \\
\hline Jefienen & $728-823.5$ & & 7288407 & Ak12mu: & Stosen We Interin & P.0. $\operatorname{Box} 987$ & Chartes Town & 254140997 \\
\hline Kanawhe & $346-7732$ & 214 & 3407736 & 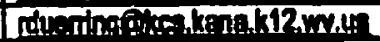 & Roneld Duenth (D., ) & 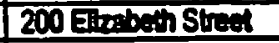 & Charteation & 25311.2119 \\
\hline Lewh & 2098300 & 128 & 2638306 & 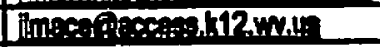 & Joseph L Mace (Dr.) & 239 Cout Avenue & Woston & $26452-2002$ \\
\hline Lineoln & 8243033 & 227 & $824 \pi 97$ & 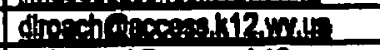 & David Roagh & 10 Meriend Avenue & Hemilin & $25523-1020$ \\
\hline Lofer & 7922.2040 & & $762-6315$ & 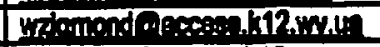 & Wilne Zipnond & 506 Hour Avmus & $\log n$ & $25601-04 \pi$ \\
\hline Maton & 367.2100 & 11 & 367.2111 & 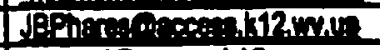 & 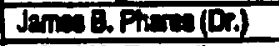 & 200 Gaten Avente: & Faiment & 265542778 \\
\hline Mrothe & 843400 & 304 & 8434400 & 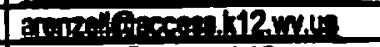 & Alind N. Renedia & P.0. $\operatorname{Ban} 578$ & Moundovile & $26041-0570$ \\
\hline Masen & $676-4640$ & 18 & $676-729$ & 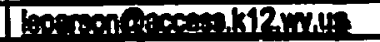 & Lam E Praon (D.) & 1200 Meh Stroe & Point Pleagente & $2550-1298$ \\
\hline Mores & 487.1651 & 241 & $426-6044$ & 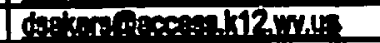 & Defom s. Ahen (O.) & 1403 Honater Ala. & Pincoston & $24740-3040$ \\
\hline Mhard & 7884200 & 13 & 7884204 & 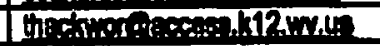 & 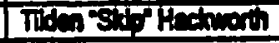 & On Bater Pleas & Koyer & 267262699 \\
\hline Mhos & 236.2333 & 206 & $226-3110$ & mk12,mu: & Dwoth Digh & Fit2 $\operatorname{Box} 310$ & Willamson & 25691.9740 \\
\hline Nonongers & 291.9210 & 500 & 2013016 & 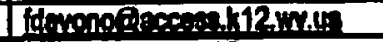 & Frank Dovono & 13 South High SL & Margentom & 26501.7546 \\
\hline Nonios & $772-3094$ & & $772-6000$ & 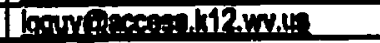 & Lin Gur (Dr.) & P.0.800 330 & Union & $24983-0330$ \\
\hline Morgan & $258-2130$ & 17 & $258-9146$ & 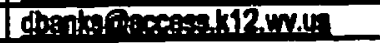 & Davd Banke & 247 Haritson Ave. & Berkeloy Sptinge & 25411.1509 \\
\hline NeDorice & $436-841$ & 220 & 4384000 & 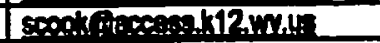 & Surette Cooth & 30 Centril Avonits & Welch & $24601-2099$ \\
\hline Nicholon & $872-3811$ & 129 & $872+629$ & 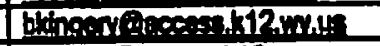 & Bowerb/ Kangen & 400 Od Mein Ditu & Summeravile & $26651-1380$ \\
\hline Ohb & $243-0000$ & 311 & $243-0328$ & 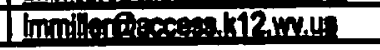 & Lamence M. Milles & 2203 Netionel Rosd & Wheeling & $26003-5203$ \\
\hline
\end{tabular}

\begin{tabular}{|c|c|c|c|c|c|c|c|c|}
\hline COUNTY & PHONE & EXI & FAX & Em Adther. & SUPERINTEMDENT & ADOAESTin & $\therefore \mathrm{CN}$ & $21 \cos 3$ \\
\hline Pendletion & $358-2207$ & & $358-2938$ & 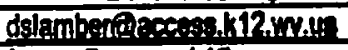 & Doydlan Lambert & POEOX 860 & Franklln & 268070060 \\
\hline Pleasants & 6842215 & & 6843569 & 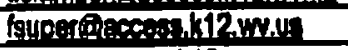 & F. Joo Super & 2272 N. Plogends HWy. & SL. Mare & 20170.0210 \\
\hline Pocahiontas & $799-4600$ & 2227 & 7994498 & iplawerecenth12 wrus & J. Patrach Law (Dr.) & 928 Fifith Avenue & Marlinton & $2485+1290$ \\
\hline Preston & 3290580 & 226 & 3290720 & jlofink@recenk12 & John Lofink & 300 Presten Ditve & Kngmood & 26637.1501 \\
\hline Punam & $586-0500$ & 104 & $586-0553$ & 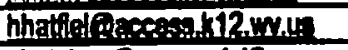 & Harol Chuct Hothed & 9 Courthouas Ditve & Wintied & 252139340 \\
\hline Raloigh & $256-4500$ & 3307 & 2584739 & chutchengerosen k12, m,un & Chartot Huthenes( & 105 Ader Street & Beckter & 25801.2791 \\
\hline Randolph & $636-9150$ & 107 & $636-8157$ & 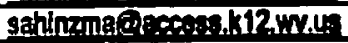 & Susan Hlinemgn & 40 Eoventh Stroed & Eldres & 26241.3512 \\
\hline Ritehio & $643-2991$ & 1 & 643.2994 & 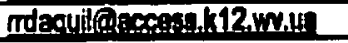 & Robert Dequilants & 134 So. Porn Ave. & Hartoville & 26392,0216 \\
\hline Roane & 927.6400 & & 927.6402 & 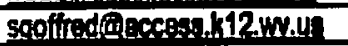 & Slephen F. Goffrede & P.0. B0x 600 & Sponcer & $25276-0609$ \\
\hline Summers & $466-6005$ & & $466-6008$ & 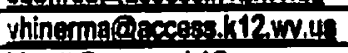 & Vects S. Hinermen & 116 Main Streat & Hinton & 25951.2439 \\
\hline Taylor & 265.2497 & 31 & $265-2508$ & idwattaacess.k12.un.4R & J. Dian Wat & POBOX 160 & Grafton & 263548618 \\
\hline Tucker & 478.2771 & & $478-3422$ & Whicksagcen k12 wath & RlchardH. Heckes & 501 Chestrut Stred & Pasone & $26287-1005$ \\
\hline Tyler & $758-2145$ & & $750-4568$ & 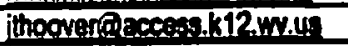 & Jefl Hoover & P.O. BOX 25 & Middleboume & 2614900026 \\
\hline Upshur & $472-5480$ & 1018 & $472-0258$ & 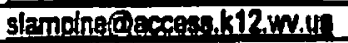 & Scoth M Lampinen & 102 Smithiold St. & Bucthannion & $26201-0560$ \\
\hline Nayne & 272.5118 & 324 & $272-6500$ & 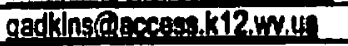 & Gay Adklns & POBOX 70 & Wayne & $25570-0070$ \\
\hline Nebster & 347.5638 & 113 & $847-2538$ & 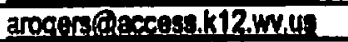 & A.J.Rogen & 315 South Maln St & Wobutin Springe & $26288-1123$ \\
\hline Vetzet & 455.2441 & 119 & $455-3446$ & 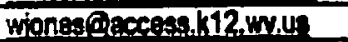 & Willam F. Jonea & 333 Foundry Stred & Now Northsovilis & $26155-1110$ \\
\hline : Vint & $275-4279$ & & $275-4581$ & 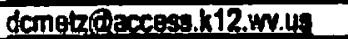 & Daniel Motz & P.O. Box 169 & Ellzaboth & $26143-0189$ \\
\hline .1000 & $420-9663$ & 125 & $420-9513$ & wnidareacess,k12,wn,us & Wililam A. Niday & 1210 Thiteenth SL & Parkersburg & $26101-4198$ \\
\hline & $732-6262$ & 105 & 732.7226 & 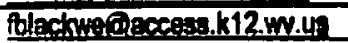 & Frank L Elackwal & P.O. Box 69 & Pinevillo & 246740069 \\
\hline
\end{tabular}




\section{WestVirginiaUniversity}

College of Human Resources and Education

Dear Superintendent,

You have been selected as a school superintendent in West Virginia to participate in a research survey to determine the relationship between the leadership images of superintendents in West Virginia and their directed modes of thinking. Your assistance in providing information about leadership images and directed modes of thinking of superintendents will make this study valuable to current and emerging superintendents. Also, the information will be valuable to those who prepare programs for educational leaders.

Enclosed are two surveys for you to complete. The surveys are the Bolman and Deal's Leadership Image Inventory and the Keirsey FourTypes Sorter. Your participation in this study is entirely voluntary and you are under no obligation to answer every question. There will be no penalty to your employment status if you choose not to participate. Your responses will be completely anonymous and confidentiality will be maintained. Furthermore, your data will be aggregated with all other responses in such a way that no person will be identified as an individual respondent. The enclosed demographic questionnaire has been reviewed by education professionals. Also, West Virginia University's IRB acknowledgement is on file. If you would like to receive the results of the completed study, please send your email request to dvargo@access.k12.wv.us.

I am conducting this research as part of my Doctoral program in Educational Leadership at West Virginia University. I hope you will have time in your busy schedule to contribute to this research. Return of your three questionnaires in the enclosed stamped, addressed envelope before August 1, 2008 would be greatly appreciated. If you have any questions, or need assistance, please contact me at 304-243-0330. Thank you.

Sincerely,

Dianna M. Vargo

Doctoral Candidate

Department of Educational Leadership

Dr. Richard Hartnett

Committee Chairman

Educational Leadership

West Virginia University 


\section{WestKrginiaUniversity}

College of Human Resources and Education

August 23, 2008

Dear Superintendent,

You may recall a survey you received earlier this month regarding the leadership images and directed modes of thinking of superintendents. This study focuses on the current West Virginia Superintendents.

I have not received your response; therefore, I have enclosed the two surveys for you to complete. The surveys are the Bolman and Deal's Leadership Image Inventory and the Keirsey FourTypes Sorter. Your participation in this study is entirely voluntary and you are under no obligation to answer every question. There will be no penalty to your employment status if you choose not to participate. Your responses will be completely anonymous and confidentiality will be maintained. Furthermore, your data will be aggregated with all other responses in such a way that no person will be identified as an individual respondent. The enclosed demographic questionnaire has been reviewed by education professionals. Also, West Virginia University's IRB ackowledgement is on file. If you would like to receive the results of the completed study, please send your email request to dvargo@access.k12.wv.us.

I am conducting this research as part of my Doctoral Program in Educational Leadership at West Virginia University. Please place the two surveys and the questionnaire in the envelope and return to me. Your time and support are appreciated. Thank you.

Sincerely,

Dianna M. Vargo

Doctoral Candidate

Department of Educational Leadership

Dr. Richard Hartnett

Committee Chairman

Educational Leadership

West Virginia University

F́dicatlonal Leaderanip Studles 


\section{"Y.WestVirginiaUniversity. \\ Office of Research Compliance}

\section{Expedited - IRB Protocol - Exemption}

$\begin{array}{ll}\text { To: } & \text { Hartnett, Richard } \\ \text { From: } & \text { WWU Office of Research Compliance } \\ \text { Date: } & \text { Monday, July 07, 2008 } \\ \text { Subject: } & \text { No action required }\end{array}$

Tracking \#: $\mathrm{H}-21033$

Title: $\quad$ A Study of the Relationship between the Leadership Images of West Virginia Superintendents and Directed Modes of Thinking

The above-referenced study was reviewed by the Institutional Review Board and was granted exemption on 7/7/2008 in accordance with 45 CFR 46.101(2).

While no action is required on your part, the IRB made the following findings:

This research study was granted an exemption in accordance with Research that involves educational tests, survey procedures, interview procedures or observation of public behavior [45 CFR 46.101(2)]. If you have questions please refer to the IRB website.

The following documents have been approved and validated for use in this study and are available in the BRAAN system:

Cover letter

Thank you.
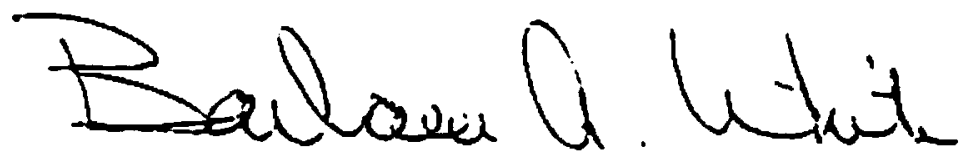

Board Designee: White, Barbara

Letter Sent By: White, Barbara, 7/7/2008 3:09 PM

Once you begin your human subject research the following regulations apply:

1. Unanticipated or serious adverse events/side effects encountered in this research study must be reported to the IRB within five (5) days. 
2. Any modifications the study protocol or informed consent form must be reviewed and approved by the IRB prior to implementation.

3. You may not use a modified informed consent form until it has been approved and validated by the IRB. 


\section{CITI Collaborative Institutional Training Initiative Human Research Currlculum Completlon Report Printed on Monday, February 11, 2008}

Learner: Dianna Vargo (Username: maryvargo) Instltutlon: West Virginla University Contact Information Email: dvargo@access.k12.wv.us

Social \& Behavioral Research Investigatore:

Stage 2. Retresher 2 Course Passed on 02/11/08 (Ref \# 1586992)

\begin{tabular}{|l|c|}
\hline Required Modules & $\begin{array}{c}\text { Date } \\
\text { Completed }\end{array}$ \\
\hline SBR 101 REFRESHER MODULE 1. History and Ethics & $02 / 06 / 08$ \\
\hline SBR 101 REFRESHER MODULE 2. Regulatory Overview & $02 / 06 / 08$ \\
\hline SBR 101 REFRESHER MODULE 3. Fundamental Issues. & $02 / 11 / 08$ \\
\hline SBR 101 REFRESHER MODULE 4. Vulnerable Subjects & $02 / 06 / 08$ \\
\hline SBR 101 REFRESHER MODULE 5. Additional Topics & $02 / 06 / 08$ \\
\hline $\begin{array}{l}\text { How to Complete The CITI Refresher Course and Receive the } \\
\text { Completion Report }\end{array}$ & $02 / 06 / 08$ \\
\hline West Virginia University & $02 / 11 / 08$ \\
\hline
\end{tabular}

For thls Completion Report to be valld, the learner llsted above must be affillated with a CITI particlpating institution. Falsifled information and unauthorized use of the CITI course site is unethical, and may be considered scientifle misconduct by your institution.

Paul Braunschweiger Ph.D.

Professor, University of Miami

Director Offlce of Research Education

CITI Course Coordinator 
Dear Ms. Vargo:

I am most pleased to learn that your doctoral research investigates the leadership images of West Virginia superintendents and their directed modes of thinking. The results of this study will be both interesting and informative to many of us as we work with local superintendents. I encourage you to share your results with the West Virginia Association of School Administrators (WVASA) and with Howard O'Cull, Executive Director of the West Virginia Schools Boards Association.

In your June letter telling me of your study within West Virginia University's Educational Leadership Doctoral Program, you asked permission to distribute the survey you are using in your study at the next superintendent's meeting. While I am most supportive of your work, I have not scheduled such gathering of data to take place at the two Superintendents' Leadership Institutes I conduct during the school year. I believe a more appropriate venue for such data gathering is at one of the monthly WVASA business meetings. To make the necessary arrangements for this, you will want to contact Dr. Martha Dean, WWASA Executive Director, at mdean@wvasa.org or by phone at (304) $455-1017$.

You might also want to consider conducting your survey electronically as local superintendents are most skilled today in using technology for work productivity purposes. The vast majority of communications from my office to local superintendents now are sent via email, and we have found responses to be both timely and thorough.

I wish you well in your pursuit of the Ed.D. and look forward to receiving a report of your study.

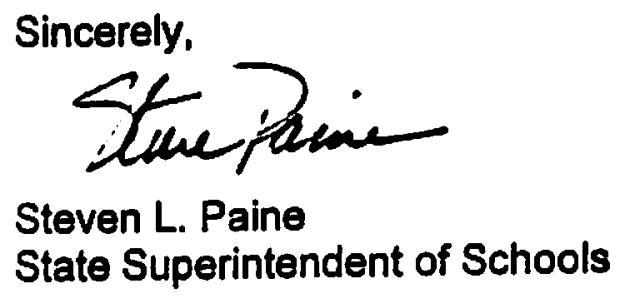




\section{Dianna M. Vargo}

1269 National Road, \#41

Wheeling, WV 26003

Home Phone: 304-243-9038

Email Address: dvargo@access.k12.wv.us

\section{Education}

- Presently enrolled in Educational Leadership Doctoral Cohort III at West Virginia University. Expected graduation date is May, 2009.

- Master of Arts in Education Administration, West Virginia University, Morgantown, West Virginia. August, 1993.

Professional Administrative Certification

Superintendent

Supervisor General Instruction

Principal Elementary/Middle/Junior High/Senior High

Vocational Administration

- Masters of Arts in Science/Mathematics Education, Wheeling Jesuit College, Wheeling, West Virginia. May, 1987.

- Bachelor of Arts and Sciences, Ohio University, Athens, Ohio.

Major: Mathematics; Minor: Computer Science. June, 1981.

Teaching Certification

Mathematics, 7-12

\section{Professional Experience}

- 2005 to present: Assistant Superintendent, Ohio County Schools, Wheeling, West Virginia.

- 2001 to 2005: Principal, Wheeling Park High School, Wheeling, West Virginia.

- 1993 to 2001: Assistant Principal, Wheeling Park High School, Wheeling, West Virginia.

- 1991 to 1993: Mathematics Department Chairperson, Wheeling Park High School, Wheeling, West Virginia.

- 1983 to 1993: Mathematics Teacher, Wheeling Park High School, Wheeling, West Virginia. 
- 1983 to 1993: Coordinator of Math/Science Novell Network Computer Laboratory, Wheeling Park High School, Wheeling, West Virginia.

- 1986: Mathematics Teacher, Wheeling Jesuit College, Wheeling, West Virginia. Taught Precalculus during summer school session.

- 1982 to 1983: Mathematics Specialist, West Liberty State College, West Liberty, West Virginia.

- 1983: Mathematics Teacher, Ohio University Belmont Campus, St. Clairsville, Ohio. Taught Basic Math 101 during Winter Quarter.

- 1981 to 1982: Mathematics Teacher, Bishop Donahue High School, McMechen, West Virginia.

\section{Extra-Curricular Experience}

- 1991 to 1993: Math Club Advisor, Wheeling Park High School.

- 1984 to 1991: Assistant Track Coach, Wheeling Park High School.

- 1989 to 1990: Head Cross Country Coach, Wheeling Park High School.

- 1984 to 1988: Assistant Cross Country Coach, Wheeling Park High School.

- 1981 to 1982: Varsity Cheer Coach, Bishop Donahue High School.

\section{Professional Leadership}

- Association For Supervision and Curriculum Development, Member

- Ohio County Schools Foundation, President

- Ohio County Schools Leadership Team

- Ohio County Schools Principal and Teacher Mentor

- Ohio County Schools Title I Parent Advisory Council, Director

- RESA-6 County Professional Development, Member

- RESA-6 Principal's Regional Institute Advisory Council, Member

- WESTEST 2 State Assessment Advisory Committee, Team Leader

- West Virginia Association of School Administrators, Member

- West Virginia Secondary School Activities Commission, Academic Achievement Award Committee Member

- Wheeling Area Chamber of Commerce Leadership Alumni, Member

\section{Community Leadership}

- Civitan of Wheeling, Chairperson of Education Committee

- Crittenton Services, Inc., Educational Advisory Board Member

- Ohio Valley Athletic Conference Executive Board, President

- Ohio Valley Athletic Conference Evening With The Stars, Director

- Ohio Valley Athletic Conference Varsity Board, Founder and Director

- Salvation Army Board of Directors, Member

- YWCA Racial Justice, Martin Luther King, Jr. Committee Member

- YMCA Corporate Team 5K, Team Leader 


\section{Awards}

- Tandy Technology Scholars Outstanding Math Teacher Award: 1992

- Tandy Technology Scholars Outstanding Math Teacher Award : 1993

- Wheeling Park High School Student Council Eagle Award : 1994

- Easter Seals Network Celebration Appreciation Award : 1995

- Commendation for Volunteer Service to the State of West Virginia by Governor Wise: 2004

- Ogden Newspapers Distance Race Hall of Fame: 2005

- The Ohio University Eastern Sports Hall of Fame: 2008

- Drs. John and Barbara Pisapia Award For Doctoral Research from the West Virginia University for doctoral study: 2008

\section{Community Service}

- 1992 to present: $S^{3}=$ Students Shop for Seniors, Founder and Director

National and State Print Media Recognition of Program:

CRF Network, Spring 1995, Vol. 5, No. 2, p.6

Service Learning in West Virginia, June 2000, pp. 139-41 